\title{
Assistenten en medewerkers in de openbare apotheek: arbeidsmarktmonitor apotheekbranche 2003-2004
}

Citation for published version (APA):

Sieben, I. J. P., de Grip, A., \& Hensen, M. M. (2004). Assistenten en medewerkers in de openbare apotheek: arbeidsmarktmonitor apotheekbranche 2003-2004. Researchcentrum voor Onderwijs en Arbeidsmarkt, Faculteit der Economische Wetenschappen. ROA Reports No. 9 https://doi.org/10.26481/umarep.2004009

Document status and date:

Published: 01/01/2004

DOI:

10.26481/umarep.2004009

Document Version:

Publisher's PDF, also known as Version of record

Please check the document version of this publication:

- A submitted manuscript is the version of the article upon submission and before peer-review. There can be important differences between the submitted version and the official published version of record.

People interested in the research are advised to contact the author for the final version of the publication, or visit the DOI to the publisher's website.

- The final author version and the galley proof are versions of the publication after peer review.

- The final published version features the final layout of the paper including the volume, issue and page numbers.

Link to publication

\footnotetext{
General rights rights.

- You may freely distribute the URL identifying the publication in the public portal. please follow below link for the End User Agreement:

www.umlib.nl/taverne-license

Take down policy

If you believe that this document breaches copyright please contact us at:

repository@maastrichtuniversity.nl

providing details and we will investigate your claim.
}

Copyright and moral rights for the publications made accessible in the public portal are retained by the authors and/or other copyright owners and it is a condition of accessing publications that users recognise and abide by the legal requirements associated with these

- Users may download and print one copy of any publication from the public portal for the purpose of private study or research.

- You may not further distribute the material or use it for any profit-making activity or commercial gain

If the publication is distributed under the terms of Article $25 \mathrm{fa}$ of the Dutch Copyright Act, indicated by the "Taverne" license above, 


\section{Assistenten en medewerkers in de openbare apotheek: Arbeidsmarktmonitor \\ Apotheekbranche 2003-2004}

ROA-R-2004/9

Inge Sieben

Andries de Grip

Maud Hensen

Researchcentrum voor Onderwijs en Arbeidsmarkt

Faculteit der Economische Wetenschappen en Bedrijfskunde Universiteit Maastricht

Maastricht, december 2004 
ISBN 90-5321-398-8

Sec04.089.doc 


\section{Inhoud}

Bladzijde

Voorwoord

Resumé $\quad$ iii

1 Arbeidsmarktmonitor Apotheekbranche: werknemersonderzoek 1

1.1 Arbeidsmarktmonitor Apotheekbranche 1

1.2 Werknemersonderzoek 2

1.3 Opzet van het rapport 3

2 Apotheekmedewerkers en het nieuwe functiewaarderingssysteem 5

2.1 Het nieuwe functiewaarderingssysteem 5

$\begin{array}{lll}2.2 & \text { De achtergrond van apotheekmedewerkers } & 7\end{array}$

$\begin{array}{ll}2.3 \text { Werkervaring en opleiding } & 10\end{array}$

$\begin{array}{ll}2.4 \text { Verbeterde arbeidsvoorwaarden? } & 15\end{array}$

2.5 Loopbaan- en arbeidsmarktperspectieven van apothekersassisten-
ten

3 Ontwikkelingen in het werk binnen de apotheek 21

3.1 Veranderingen in het werk 21

$\begin{array}{ll}3.2 & \text { Takenpakket en werkverdeling } \\ 3.3 & 22\end{array}$

$\begin{array}{lll}3.3 & \text { Flexibele inzet } & 30\end{array}$

$\begin{array}{lll}3.4 & \text { Werkdruk en ziekteverzuim } & 35\end{array}$

3.5 Tevredenheid met het werk 40

4 Competenties van apotheekmedewerkers $\quad 43$

4.1 Competenties 43

4.2 Het op peil houden van het competentieniveau 52

4.3 Competenties, werkdruk, ziekteverzuim en tevredenheid 53

4.4 Competenties en loopbaanverwachtingen 59

5 Scholing van apotheekmedewerkers $\quad 63$

5.1 Participatie in cursussen 63

$\begin{array}{ll}5.2 \text { Het nut van scholing } & 69\end{array}$

$\begin{array}{lll}5.3 & \text { Behoefte aan verdere scholing } & 71\end{array}$

$\begin{array}{lll}5.4 & \text { HRM-beleid en scholing } & 75\end{array}$

Bijlage A: vragenlijst apothekersassistenten en

Bijlage B: vragenlijst overige medewerkers $\quad$ v.a. blz. 79 



\section{Voorwoord}

In 2001 is in opdracht van de Stichting Bedrijfsfonds Apotheken (SBA) een start gemaakt met de Arbeidsmarktmonitor Apotheekbranche. Tijdens de eerste cyclus van deze monitor zijn een viertal deelonderzoeken door het Researchcentrum voor Onderwijs en Arbeidsmarkt (ROA) uitgevoerd, waarin werkgevers (apothekers), werkende apothekersassistenten, schoolverlaters van de opleiding tot apothekersassistent en apothekersassistenten die voorheen in de openbare apotheek hebben gewerkt werden ondervraagd. Als sluitstuk van de eerste cyclus is een toekomstverkenning van de arbeidsmarkt voor apothekersassistenten opgesteld. ${ }^{1}$

In 2003 is de tweede cyclus van de Arbeidsmarktmonitor Apotheekbranche van start gegaan. Hiertoe zijn eerst verkennende gesprekken met verschillende partijen in de apotheekbranche gehouden. ${ }^{2}$ Op basis van deze gesprekken is gekozen voor een opzet waarin als eerste een enquêteonderzoek onder apothekers gehouden zou worden. De resultaten van dit werkgeversonderzoek zijn te vinden in het rapport 'Apothekers en de openbare apotheek: Arbeidsmarktmonitor Apotheekbranche 2003-2004'. In het rapport dat nu voor $\mathrm{u}$ ligt wordt verslag gedaan van het tweede onderdeel van de monitor: het werknemersonderzoek. Hiertoe werden begin 2004 enquêtes gehouden onder apothekersassistenten en overige medewerkers in de openbare apotheek.

Behalve door de auteurs is er bij het Researchcentrum voor Onderwijs en Arbeidsmarkt (ROA) aan dit rapport meegewerkt door dhr. S. Dijksman. Daarnaast zijn we dank verschuldigd aan dhr. M. van Aken, dhr. M. Dikshoorn en dhr. D. Wenting van het Pensioenfonds Medewerkers Apotheken (PMA) voor het beschikbaar stellen van de adressen van apotheekmedewerkers, aan mevr. M. Lennertz en medewerkers van apotheek Hatert te Nijmegen voor de medewerking aan een proefenquête en aan mevr. J. Stijlen, dhr. F. Willemsen en dhr. L. Schreurs van Intomart GfK voor het uitvoeren van het veldwerk. Ten slotte willen we mevr. E. de Vaal, dhr. P. Georgopoulos en dhr. J. Sax van der Weijden van de Stichting Bedrijfsfonds Apotheken (SBA) bedanken voor hun inbreng bij de samenstelling van de vragenlijsten en de beschrijving van de onderzoeksresultaten in dit rapport.

1. Zie:

- F. Cörvers, B. Diephuis en B. Golsteyn (2002). Het onbenutte arbeidspotentieel van apothekersassistenten voor de openbare apotheek, ROA-R-2002/2, Maastricht.

- A. de Grip, J. Sanders en I. Sieben (2002). Knelpunten op de arbeidsmarkt en personeelsbeleid in de openbare apotheek, ROA-R-2002/11, Maastricht.

- A. de Grip en I. Sieben (2002). Werken in de openbare apotheek, ROA-R-2002/13, Maastricht.

- J. Sanders, R. de Vries en M. Wolbers (2003). Apothekersassistenten van school naar werk, ROA-R-2003/5, Maastricht.

- A. de Grip, M. Hensen en I. Sieben (2003). De arbeidsmarkt voor apothekersassistenten tot 2010: een toekomstverkenning, ROA-R-2003/6, Maastricht.

2. J. Sanders, I. Sieben en A. de Grip (2003). Arbeidsmarktmonitor Apotheekbranche. Verkenning opzet tweede cyclus (2003-2005). ROA-W-2003/2, Maastricht. 


\section{Resumé}

In deze rapportage wordt verslag gedaan van een onderzoek onder apothekersassistenten en overige medewerkers in de openbare apotheek. Dit werknemersonderzoek, waartoe in februari en maart 2004 bijna 4.300 apotheekmedewerkers zijn ondervraagd, maakt deel uit van de tweede cyclus van de Arbeidsmarktmonitor Apotheekbranche, die het Researchcentrum voor Onderwijs en Arbeidsmarkt (ROA) in opdracht van de Stichting Bedrijfsfonds Apotheken (SBA) uitvoert. De resultaten van het onderzoek onder werkgevers (apothekers) zijn te vinden in het eerder verschenen rapport 'Apothekers en de openbare apotheek: Arbeidsmarktmonitor Apotheekbranche 2003-2004'.

\section{Apotheekmedewerkers en het functiewaarderingssysteem}

Per 1 april 2003 is een functiewaarderingssysteem in de openbare apotheken ingevoerd. Het scala aan functies aanwezig in de openbare apotheek wordt aan de hand van dit systeem ingedeeld in functiecategorieën. Naast 'gewone' apothekersassistenten en apothekersassistenten in een variant-functie werken er in de openbare apotheek leerling-apothekersassistenten, apotheekhulpen, bezorgers, schoonmakers en administratieve krachten die een ondersteunende rol spelen. De meeste apotheekmedewerkers zijn tevreden met de indeling in het functiewaarderingssysteem.

Het beroep van apothekersassistent is nog steeds een echt vrouwenberoep. Minder dan $1 \%$ van de apothekersassistenten werkzaam in de openbare apotheek is een man. Ook bij de overige apotheekmedewerkers is het merendeel vrouw. De functie van bezorger wordt echter wel vaak door mannen (58\%) vervuld. Assistenten zijn gemiddeld wat jonger (37 jaar) dan de overige apotheekmedewerkers (42 jaar).

Het is opvallend dat tegenwoordig meer apothekersassistenten $(57 \%)$ één of meer thuiswonende kinderen hebben dan in 2001 (49\%). Dit duidt erop dat het werk in de openbare apotheek voor veel assistenten goed te combineren is met de zorg voor kinderen. Vergeleken met 2001 is niet alleen het percentage assistenten dat thuiswonende kinderen heeft, maar ook het aandeel assistenten dat de zorg draagt voor een jong kind toegenomen. $40 \%$ van de assistenten met thuiswonende kinderen heeft een kind dat jonger is dan 4 jaar. $24 \%$ van de apothekersassistenten met thuiswonende kinderen heeft een kind tussen 5 en 9 jaar.

Gemiddeld genomen heeft een apotheekmedewerker bijna 17 jaar werkervaring zowel binnen als buiten de openbare apotheek. Een apothekersassistent in een variant-functie blijkt gemiddeld over meer werkervaring binnen de apotheek (17 jaar) te beschikken dan een 'gewone' apothekersassistent (14 jaar). Blijkbaar zijn met name de assistenten die al lang in de openbare apotheek werkzaam zijn, met de invoering van het functiewaarderingssysteem tot variant-assistent gepromoveerd. Ook blijken variant-assistenten aanmerkelijk langer in de huidige apotheek te werken (gemiddeld 11 jaar tegenover 8 jaar voor de 'gewone' assistenten). 
Alle apothekersassistenten hebben uiteraard dezelfde scholing genoten, namelijk de MBO-opleiding tot apothekersassistent. De meeste overige apotheekmedewerkers hebben een algemene opleiding (bijvoorbeeld MAVO) afgerond. Apotheekhulpen hebben relatief vaak een opleiding in de paramedische en farmaceutische richting genoten. Zoals verwacht mocht worden, heeft $26 \%$ van de administratieve en secretariële medewerkers een opleiding in de economische en administratieve richtingen afgerond. Bezorgers hebben vaak een technische achtergrond.

\section{Betere arbeidsvoorwaarden?}

Veel apotheekmedewerkers hebben een vast contract. Met name de apothekersassistenten die in een variant-functie werkzaam zijn (98\%) en schoonmakers (95\%) hebben vaak een vast contract. De jongere apotheekmedewerkers en de medewerkers met weinig werkervaring zijn vaker volgens een tijdelijk contract werkzaam. Apothekersassistenten hebben tegenwoordig minder vaak een vast contract en vaker een tijdelijk contract met uitzicht op een vast contract dan in 2001. Wellicht maakt de huidige economische en politieke situatie de apothekers voorzichtiger in het aanbieden van vaste contracten.

Het bruto maandsalaris bij een 36-urige werkweek is gemiddeld het hoogst voor apothekersassistenten die een variant-functie hebben: $€ 2.177,-$. De 'gewone' apothekersassistenten krijgen gemiddeld $€ 2.013$,- per maand. De BBL'ers verdienen het minste per maand, namelijk $€ 1.353,-$. De verschillen in verdiensten worden veroorzaakt door de inschaling volgens het functiewaarderingssysteem. Zo worden BBL'ers (samen met apotheekhulpen en bezorgers) in schaal 3 ingedeeld. Apothekersassistenten zijn ingeschaald in schaal 6 en de variant-assistenten in schaal 7. De hoogte van het salaris hangt verder af van leeftijd en ervaring. Vergeleken met de situatie in 2001 is het bruto maandsalaris van apothekersassistenten gestegen van $€ 1.802$,- naar $€ 2$ 2.013. De CAO lonen stegen in de periode 2001-2004 met ongeveer $7 \%$ waardoor de loonstijging ten gevolge van het functiewaarderingssysteem uitkomt op $6 \%$ over de gehele periode.

\section{Loopbaan- en arbeidsmarktperspectieven}

$75 \%$ van de apothekersassistenten denkt over 5 jaar nog altijd werkzaam te zijn in dezelfde openbare apotheek waar ze momenteel werken. Dit is beduidend meer dan in 2001 , toen nog $69 \%$ van de assistenten aangaf over 5 jaar in dezelfde apotheek te werken. Ook zijn er tegenwoordig minder assistenten op zoek naar een andere baan ( $8 \%$ tegenover $11 \%$ in 2001). Het lijkt er dus op dat met de invoering van het functiewaarderingssysteem een stap is gezet om meer apothekersassistenten voor de apotheekbranche te behouden.

\section{Ontwikkelingen in het werk binnen de apotheek}

Het is opvallend hoe groot de afgelopen twee jaar de dynamiek in het werk van de apothekersassistenten is geweest. De meest genoemde verandering is de toegenomen mondigheid van de cliënten. Ook geeft meer dan driekwart van de assis- 
tenten aan dat de intensiteit van de patiëntenvoorlichting en het aanbod van nieuwe producten is toegenomen. Daarnaast wijzen veel assistenten op de toename van de klantgerichtheid, de vereiste geneesmiddelenkennis, de werkdruk, de handverkoop, het gebruik van ICT en de koppeling met een artsensysteem. Er is maar één activiteit die de afgelopen jaren is afgenomen: het zelf bereiden van medicijnen. $\mathrm{Er}$ is duidelijk sprake van een lange-termijn trend wat de toenemende mondigheid van cliënten, intensiteit van de patiëntenvoorlichting en klantgerichtheid betreft. Daarentegen is de toename van de handverkoop en het verplaatsen van farmaceutische zorg naar de thuissituatie juist de laatste twee jaar in een stroomversnelling geraakt.

\section{Takenpakket en flexibele inzet}

Het takenpakket van de apothekersassistenten in de variant FPZ staat in het algemeen het dichtst bij het takenpakket van de 'gewone' assistenten. Ze zijn ruim de helft van hun werktijd bezig met het aanschrijven, uitvullen en afleveren van recepten. De takenpakketten van de beide andere variant-functies zijn iets meer geprononceerd, al gaat het ook bij deze functies slechts om accentverschillen met de 'gewone' apothekersassistenten. Apotheekhulpen worden vooral ingezet bij het uitvullen van recepten en het bewaken van de voorraad. Ook verrichten ze veel 'overige taken'. BBL'ers worden verhoudingsgewijs vaak ingezet bij het uitvullen van recepten en het bereiden van geneesmiddelen.

Opvallend is dat ruim een kwart van de 'gewone' apothekersassistenten ook taken uit lagere functies verricht. Bijna evenveel assistenten voeren wel eens taken uit hogere functies uit. Variant-apothekersassistenten verrichten vaker taken uit andere functies. Dit geldt vooral voor de assistenten die werkzaam zijn in de coördinerende variant. Kennelijk vervullen deze variant-assistenten momenteel een schakelrol tussen het management van de apotheek en de assistenten in de 'gewone' assistentfuncties.

Apotheekhulpen nemen de assistenten vooral werkzaamheden uit handen waarvoor iemand geen middelbare beroepsopleiding hoeft te hebben gevolgd: schoonmaken en huishoudelijke taken, bezorgen van geneesmiddelen en recepten uitvullen. De inzet van apotheekhulpen voorkomt dus dat assistenten teveel werkzaamheden onder hun niveau moeten verrichten. Maar liefst tweederde van de apothekersassistenten vindt overigens dat apotheekhulpen hen nog meer werkzaamheden uit handen zouden kunnen nemen. Daarbij denken de assistenten aan schoonmaken en huishoudelijke taken, het bezorgen van geneesmiddelen, administratieve taken en het bewaken van de voorraad. Apotheekhulpen zouden zelf ook wel meer administratieve taken van de apothekersassistenten willen overnemen. Daarnaast zouden ze meer recepten willen uitvullen. BBL'ers zouden vooral graag meer taken willen verrichten op het terrein van de farmaceutische patiëntenzorg en het aanschrijven van recepten. In de praktijk verrichten ze deze werkzaamheden ook wat minder vaak dan de apothekersassistenten. Administratief personeel, bezorgers en schoonmakers zouden hun inzet vooral willen vergroten op de terreinen waarin ze zich reeds specialiseren; ze willen er het liefst dus niet te veel ander werk bij doen. 


\section{Werkdruk en ziekteverzuim}

De werkdruk van apotheekmedewerkers is het hoogst onder de apothekersassistenten. Daarbij is er geen verschil tussen de assistenten in een 'gewone' functie en de assistenten in een variant-functie. Ook is er weinig verschil met de BBL'ers. Met name bij de schoonmakers, maar ook bij de bezorgers en het administratief personeel ligt de werkdruk duidelijk lager.

Bijna $60 \%$ van de assistenten in een 'gewone' functie heeft zich het afgelopen jaar één of meerdere keren ziek gemeld. Gemiddeld waren zij in een jaar tijd ruim 10 dagen ziek. Het ziekteverzuim was daarmee wat hoger dan in 2001, toen het gemiddelde aantal dagen dat een assistent ziek was 9,5 dag bedroeg. Van de assistenten die werkzaam zijn in een variant-functie was iets meer dan de helft één of meerdere keren ziek. Wel was de variant-apothekersassistent gemiddeld langer ziek (12,6 dagen). Bij de overige apotheekmedewerkers was het ziekteverzuim duidelijk hoger. Het administratief en secretarieel personeel was gemiddeld zelfs 16,5 dag ziek. Overigens was het overgrote deel van het ziekteverzuim in alle functiegroepen niet aan het werk gerelateerd.

\section{Tevredenheid met het werk}

Meer dan 9 op de 10 apotheekmedewerkers is tevreden met hun werk. Vergeleken met 2001 is de tevredenheid onder de apothekersassistenten licht toegenomen. Toch blijken er wel punten van onvrede te zijn. Zo is ruim de helft van de 'gewone' apothekersassistenten niet tevreden met hun loopbaanperspectieven. In 2001 was het percentage assistenten dat niet tevreden was over hun loopbaanperspectieven weliswaar iets hoger, maar de introductie van het nieuwe functiewaarderingssysteem heeft er niet toe geleid dat de apothekersassistenten op dit punt over de gehele linie nu meer tevreden zijn.

\section{Competenties van apotheekmedewerkers}

Apothekersassistenten hebben over het algemeen, met een gemiddeld rapportcijfer van 7,5 , een erg positief beeld van hun eigen competentieniveau. De apothekers waarbij ze werkzaam zijn onderschrijven dit positieve beeld, al ligt hun waardering iets lager (gemiddeld cijfer 7,2). Assistenten geven zichzelf de hoogste cijfers voor hun algemene vaardigheden (gemiddeld cijfer 7,8), maar ook hun vakkennis en vaardigheden waarderen ze met een 7,4. Ook blijkt dat de apothekersassistenten die werkzaam zijn in een van de specialistische functies over de gehele linie zichzelf een hoger cijfer geven scoren dan de assistenten die in een 'gewone' functie werkzaam zijn.

Apothekersassistenten geven zichzelf relatief de laagste cijfers voor secretariële werkzaamheden, het realiseren, bewaken en bevorderen van kwaliteitsbeleid, leidinggeven en kennis van wet- en regelgeving. Deze relatief lagere cijfers ondersteunen de verticale functiedifferentiatie die er op basis van het nieuwe functiewaarderingssysteem in de apotheekbranche is doorgevoerd. Voor een aantal compe- 
tenties kan er een vergelijking worden gemaakt met de rapportcijfers die de assistenten zichzelf in 2001 gaven. Het is opmerkelijk dat, terwijl de beoordeling van de algemene vaardigheden hetzelfde is gebleven, de assistenten met name hun vakkennis momenteel hoger inschatten dan enkele jaren geleden.

De BBL'ers achten hun eigen competenties in het algemeen ook voldoende om goed te kunnen functioneren. Dit wijst erop dat assistenten die de beroepsbegeleidende leerweg volgen na het behalen van hun diploma direct goed inzetbaar zijn als apothekersassistent. Apotheekhulpen doen in hun eigen ogen weinig onder voor de assistenten voor wat betreft hun algemene vaardigheden. Uit hun competentiescores blijkt dat het inzetten van apotheekhulpen volgens henzelf vooral efficiënt is wanneer er een beroep wordt gedaan op hun competenties op het terrein van mondelinge en schriftelijke communicatie, computervaardigheden en voorraad- en magazijnbeheer.

\section{Het op peil houden van het competentieniveau}

Het leren op de werkplek wordt voor het verwerven van de meeste competenties vaak gezien als de beste leerweg. Alleen voor het op peil houden van de kennis van geneesmiddelen en zelfzorgartikelen is het volgen van een cursus volgens velen de meest geschikte leerweg. Bij alle competenties is er echter ook een aanzienlijke groep assistenten die vindt dat competenties het beste op peil gehouden kunnen worden door het volgen van cursussen. Teamtrainingen zijn daarbij volgens de assistenten alleen optimaal voor het verbeteren van de mondelinge en schriftelijke communicatie. Van e-learning wordt in het algemeen nog weinig verwacht. Deze leerweg lijkt nog het meeste perspectief te bieden voor het op peil houden van computervaardigheden en de kennis van geneesmiddelen en zelfzorgartikelen.

\section{Competenties, werkdruk, ziekteverzuim en tevredenheid}

Bij verschillende competenties blijkt dat juist degenen die vinden dat ze op een bepaald gebied goed zijn, een grotere werkdruk ervaren. Daar staat echter tegenover dat apotheekmedewerkers met een hoge score voor hun stressbestendigheid significant minder vaak vanwege ziekte hun werk verzuimen. Bij de variant-assistenten, BBL'ers en apotheekhulpen blijkt bovendien dat degenen met een hoog cijfer voor hun omgang en samenwerking met collega's zich minder vaak ziekmelden of minder lang ziek zijn.

De apothekersassistenten die zichzelf een hoog cijfer geven voor hun deskundigheid en zelfstandigheid zijn zowel meer tevreden met de inhoud van hun werk, als met het salaris en loopbaanperspectief. Bovendien zijn deze assistenten meer tevreden over het leiding geven door de apotheker. Ze zijn echter minder tevreden over de zelfstandigheid waarmee ze hun werk kunnen uitvoeren. Dit wijst erop dat ze meer handelingsvrijheid zouden willen hebben. Ook de variant-apothekersassistenten met hoge scores voor bepaalde competenties zijn minder tevreden met de vrijheidsgraden die ze in hun werk hebben. 
Apothekersassistenten die voor bepaalde algemene vaardigheden en/of vakspecifieke competenties hoger scoren zijn duidelijk minder vaak actief op zoek naar een andere baan. Bovendien zijn deze assistenten minder vaak op zoek naar ander soort werk. Daarentegen blijkt bij de variant-apothekersassistenten dat degenen met een hoog cijfer voor hun omgang en samenwerking met collega's vaker op zoek zijn naar een andere baan en daarbij vooral ook denken aan ander soort werk. Dit wijst er op dat deze assistenten op zoek zijn naar een baan waar hun samenwerkingsvaardigheden nog beter tot hun recht komen.

\section{Scholing van apotheekmedewerkers}

In 2003 werd door maar liefst $75 \%$ van de apothekersassistenten één of meerdere cursussen gevolgd. Dit is beduidend meer dan de $64 \%$ in 2001 , en ook meer dan het landelijke gemiddelde in de zorgsector (53\%). De cursusparticipatie van de variantapothekersassistenten ligt overigens nog wat hoger. Daarnaast heeft $24 \%$ van de apotheekhulpen en $31 \%$ van het administratief en secretarieel personeel aan een cursus deelgenomen. Bezorgers en schoonmakers volgen nauwelijks cursussen.

Welke cursussen werden er gevolgd? De apothekersassistenten hebben met name aan scholing in kennis van geneesmiddelen (67\%) en ziektebeelden (56\%) deelgenomen. Daarnaast volgde ongeveer een kwart van de assistenten algemene cursussen op het gebied van deskundigheid en/of professionaliteit, en mondelinge en schriftelijke communicatie. Het zal geen verbazing wekken dat assistenten in de variant coördinerend daarnaast relatief vaak een cursus leidinggeven volgden, terwijl assistenten in de variant kwaliteitszorg vaak aan een cursus op het gebied van het realiseren, bewaken en bevorderen van het kwaliteitsbeleid deelnamen. De apotheekhulpen volgden ook vaak scholing in kennis van geneesmiddelen en ziektebeelden en in de algemene vaardigheden deskundigheid en/of professionaliteit en mondelinge en schriftelijke communicatie.

De cursussen werden vaak op locatie gevolgd ( $80 \%$ van de assistenten), met name de cursussen leidinggeven en bereiden van medicijnen. $15 \%$ van de assistenten participeerde in cursussen op de werkplek. Dit waren vooral algemene cursussen in mondelinge en schriftelijke communicatie, stressbestendigheid en omgang en samenwerking met collega's. Zelfstudie (eveneens 15\%) kwam met name voor bij het leren van vakkennis, terwijl e-learning (6\%) vooral bij computercursussen werd toegepast. Overigens heeft ruim een kwart van de apothekersassistenten samen met (een groot deel van) hun team aan een teamtraining deelgenomen.

Het initiatief voor het volgen van cursussen wordt door de assistenten zelf (meer dan de helft) of samen met de apotheker (ongeveer 30\%) genomen. Apotheekhulpen nemen minder vaak zelf het initiatief om een cursus te volgen. Net als in 2001 worden bijna alle cursussen door de apotheker betaald. $45 \%$ van de apothekersassistenten neemt in werktijd aan cursussen deel, of krijgen voor hun studietijd betaald. 
Ongeveer net zoveel assistenten volgen de cursussen in hun eigen (vrije) tijd, de rest volgt de cursussen deels in werktijd, deels in eigen tijd.

Het nut van scholing

Meer dan $40 \%$ van de assistenten volgt cursussen om bij te blijven. Daarnaast wil ongeveer $15 \%$ een tekort aan vaardigheden wegwerken of zich verder specialiseren. De variant-apothekersassistenten nemen vaker dan de 'gewone' assistenten aan een cursus deel om zich verder te specialiseren of om promotie te kunnen maken. Apotheekhulpen volgen ook vaak cursussen om bij te blijven, maar geven daarnaast aan cursussen te volgen uit persoonlijke interesse.

Bij een aanzienlijk deel van de assistenten is het niveau van een aantal kerncompetenties tussen 2001 en 2004 verbeterd. Het volgen van een cursus in 2003 lijkt hier echter geen direct meetbare invloed op te hebben gehad. Alleen assistenten die een cursus in kennis van ziektebeelden hebben gevolgd, gaven zichzelf in 2004 een beduidend hoger rapportcijfer dan in 2001. Toch komen de door de apotheekmedewerkers gevolgde cursussen goed van pas in hun werk. De opgedane kennis en vaardigheden worden bijna altijd door henzelf en/of door collega's gebruikt.

\section{Behoefte aan verdere scholing en HRM-beleid}

Meer dan 95\% van de assistenten en $84 \%$ van de apotheekhulpen heeft behoefte aan verdere bij- of nascholing. Het gaat dan met name om cursussen over kennis van geneesmiddelen en ziektebeelden en ICT-cursussen. Van de administratief en secretarieel medewerkers wil $65 \%$ een cursus volgen, terwijl bezorgers en schoonmakers met respectievelijk $32 \%$ en $24 \%$ de minste behoefte aan bij- of nascholing hebben.

Met ongeveer een kwart van de 'gewone' apothekersassistenten zijn afspraken gemaakt over hun persoonlijke ontwikkeling en het volgen van cursussen. Slechts $2 \%$ heeft een persoonlijk ontwikkelingsplan (POP). Voor de variant-assistenten liggen deze percentages iets hoger, terwijl met de overige apotheekmedewerkers veel minder vaak afspraken of een POP zijn gemaakt. Overigens zou ongeveer $25 \%$ tot $30 \%$ van de assistenten en apotheekhulpen graag afspraken op dit punt willen maken. Apothekersassistenten die dit al gedaan hebben, zijn zeer tevreden over de gemaakte afspraken en nemen ook vaker aan cursussen deel dan assistenten die geen afspraken gemaakt hebben. 



\section{Arbeidsmarktmonitor Apotheekbranche: werknemersonderzoek}

\subsection{Arbeidsmarktmonitor Apotheekbranche}

De apotheekbranche kampte de afgelopen jaren met aanzienlijke knelpunten op de arbeidsmarkt. Om hier goed op te kunnen inspelen heeft de Stichting Bedrijfsfonds Apotheken (SBA) begin 2001 het initiatief genomen tot het opzetten van een Arbeidsmarktmonitor Apotheekbranche. Deze monitor, die door het Researchcentrum voor Onderwijs en Arbeidsmarkt (ROA) wordt uitgevoerd, brengt een groot aantal uiteenlopende aspecten van het werken in de openbare apotheek in kaart. Hiermee beschikken werkgevers, werknemers, opleidingsinstituten en beleidsmakers over relevante informatie over de huidige en toekomstige arbeidsmarktsituatie voor werknemers in de openbare apotheek en het gevoerde personeelsbeleid in de apotheekbranche. Aan de hand van deze informatie zouden bijvoorbeeld de bovengenoemde knelpunten beter aangepakt kunnen worden, en kan een gericht opleidingsbeleid gevoerd worden.

In de eerste cyclus van de Arbeidsmarktmonitor Apotheekbranche zijn verschillende doelgroepen ondervraagd. Zo zijn er in 2001-2002 onderzoeken gehouden onder:

- Werkgevers (apothekers); ${ }^{3}$

- Werkende apothekersassistenten; ${ }^{4}$

- Schoolverlaters van de opleiding tot apothekersassistent, ${ }^{5}$

- Apothekersassistenten die voorheen in de openbare apotheek hebben gewerkt. $^{6}$

Als sluitstuk van de eerste cyclus is een toekomstverkenning van de arbeidsmarkt voor apothekersassistenten opgesteld. ${ }^{7}$

$\mathrm{Na}$ afloop van de eerste cyclus heeft een uitgebreide evaluatie van de monitor plaatsgevonden. ${ }^{8}$ Aan de hand van gesprekken met verschillende partijen in de apotheekbranche is de behoefte aan informatie per doelgroep en onderwerp vastgesteld. Op grond van deze informatiebehoefte is besloten om in de tweede cyclus van de Arbeidsmarktmonitor Apotheekbranche (2003-2004) allereerst een enquête onder werkgevers (apothekers) te houden.

3. A. de Grip, J. Sanders en I. Sieben (2002). Knelpunten op de arbeidsmarkt en personeelsbeleid in de openbare apotheek, ROA-R-2002/11, Maastricht.

4. A. de Grip en I. Sieben (2002). Werken in de openbare apotheek, ROA-R-2002/13, Maastricht.

5. J. Sanders, R. de Vries en M. Wolbers (2003). Apothekersassistenten van school naar werk, ROA-R-2003/5, Maastricht.

6. F. Cörvers, B. Diephuis en B. Golsteyn (2002). Het onbenutte arbeidspotentieel van apothekersassistenten voor de openbare apotheek, ROA-R-2002/2, Maastricht.

7. A. de Grip, M. Hensen en I. Sieben (2003). De arbeidsmarkt voor apothekersassistenten tot 2010: een toekomstverkenning, ROA-R-2003/6, Maastricht.

8. J. Sanders, I. Sieben en A. de Grip (2003). Arbeidsmarktmonitor Apotheekbranche. Verkenning opzet tweede cyclus (2003-2005). ROA-W-2003/2, Maastricht. 
De resultaten van dit werkgeversonderzoek zijn te vinden in het rapport 'Apothekers en de openbare apotheek: Arbeidsmarktmonitor Apotheekbranche 2003-2004'. Daarnaast is er begin 2004 een onderzoek onder apotheekmedewerkers gehouden. In tegenstelling tot de eerste cyclus van de monitor werden hierbij niet alleen de apothekersassistenten, maar ook de overige apotheekmedewerkers ondervraagd over het werken in de openbare apotheek. De resultaten van dit werknemersonderzoek staan in dit rapport centraal.

\subsection{Werknemersonderzoek}

Op basis van de informatie die tijdens de gesprekken met verschillende partijen uit de branche is verkregen over relevante onderwerpen voor de tweede cyclus van de Arbeidsmarktmonitor Apotheekbranche, zijn twee vragenlijsten opgesteld: één voor de werkende apothekersassistenten (inclusief de assistenten die werkzaam zijn in een van de drie variant-functies) en één voor de overige medewerkers in de openbare apotheek. Beide vragenlijsten zijn te vinden in de bijlagen van dit rapport. Om vergelijkingen in de tijd mogelijk te kunnen maken, is - waar mogelijk - aangesloten bij de vragen die in de eerste cyclus van de monitor aan de werkende apothekersassistenten gesteld zijn.

Begin februari 2004 zijn de vragenlijsten met een begeleidende brief door Intomart GfK naar 6.000 assistenten en 3.600 overige medewerkers gestuurd. Hiertoe zijn uit het adresbestand van het Pensioenfonds Medewerkers Apotheken (PMA) allereerst alle apothekersassistenten geselecteerd die eind 2001 aan het werknemersonderzoek in de eerste cyclus van de monitor hebben deelgenomen en die daarbij hebben aangegeven nog een keer vragen over het werken in de apotheek te willen beantwoorden. Van deze 1.208 assistenten kunnen de antwoorden uit 2001 en 2004 direct vergeleken worden. Daarnaast zijn alle assistenten aangeschreven die werkzaam zijn in een apotheek die eind 2003 aan het werkgeversonderzoek in de tweede cyclus van de monitor heeft deelgenomen. Dit betekent dat van deze 3.012 assistenten informatie over de apotheek waarin zij werken bekend is. Ten slotte zijn nog 1.780 apothekersassistenten en 3.600 overige medewerkers op een aselecte wijze uit het adresbestand benaderd.

Assistenten en overige medewerkers hadden vervolgens tot eind maart 2004 de tijd om de schriftelijke vragenlijst in te vullen en terug te sturen. Ook konden zij de vragenlijst via internet beantwoorden. Uiteindelijk hebben 3.213 apothekersassistenten (1.992 via de schriftelijke lijst en 1.221 via Internet) de enquête ingevuld. De respons was net zo hoog als in 2001: 54\%. Van de overige medewerkers namen 1.206 medewerkers (781 via de schriftelijke vragenlijst en 425 via Internet) aan de enquête deel. De respons van deze groep medewerkers was wat lager: $34 \%$. Wellicht waren deze medewerkers minder geneigd om aan een onderzoek over het werken in de openbare apotheek mee te werken, omdat zij zich over het algemeen wat minder bij de apotheek betrokken voelen, ook al omdat zij vaak kleine deeltijdbanen hebben. 
Overigens vormen zowel de aan de tweede cyclus van de monitor deelnemende apothekersassistenten als de deelnemende overige werknemers een representatieve afspiegeling van de apotheekmedewerkers in de openbare apotheek. ${ }^{9}$

\subsection{Opzet van het rapport}

De opzet van dit rapport is als volgt. In hoofdstuk 2 worden de verschillende functies in de openbare apotheek in kaart gebracht. Ook wordt antwoord gegeven op de vraag of de apotheekmedewerkers tevreden zijn met hun indeling in het nieuwe functiewaarderingssysteem. Daarna wordt de achtergrond van de medewerkers beschreven, zoals hun geslacht, leeftijd, gezinssituatie, etniciteit, werkervaring en opleiding. Ten slotte wordt aandacht besteed aan hun arbeidsvoorwaarden en loopbaanperspectieven.

Hoofdstuk 3 gaat in op de veranderingen in de inhoud van het werk en de taakverdeling tussen de verschillende functies in de openbare apotheek. Ook wordt een overzicht gegeven van de taken van apothekersassistenten die door apotheekhulpen worden overgenomen. Daarnaast wordt onderzocht hoe apotheekmedewerkers hun werkdruk en arbeidsomstandigheden ervaren, hoe hoog hun ziekteverzuim is en hoe tevreden ze zijn met de verschillende aspecten van hun baan.

In hoofdstuk 4 wordt ingegaan op de vraag in hoeverre apotheekmedewerkers zichzelf competent achten op de verschillende aspecten van het werk in de openbare apotheek. Bovendien wordt besproken of het oordeel van de medewerkers over hun eigen competentieniveau verschilt van dat van de apothekers en of bepaalde groepen medewerkers competenter zijn dan andere. Daarnaast wordt in dit hoofdstuk aangegeven op welke wijze de apothekersassistenten denken het beste hun competenties op peil te kunnen houden. Ook wordt de werkdruk, het ziekteverzuim, de tevredenheid met de baan en de loopbaanverwachtingen van medewerkers in verband gebracht met hun competentieniveau.

Hoofdstuk 5 brengt in kaart welke cursussen er door apotheekmedewerkers gevolgd worden. Daarnaast wordt nagegaan om welke redenen cursussen gevolgd worden en of scholing ook echt het competentieniveau bevordert. Ook wordt er antwoord gegeven op de vraag aan welke cursussen medewerkers behoefte hebben. Ten slotte komt het HRM-beleid rond scholing in de openbare apotheek aan de orde.

9. De groepen zijn op representativiteit getoetst wat geslacht, leeftijd, regio, aantal werkuren per week, inkomen en lengte dienstverband betreft. 



\section{Apotheekmedewerkers en het functiewaarderingssysteem}

In dit hoofdstuk worden de verschillende functies in de openbare apotheek in kaart gebracht. Ook wordt een antwoord gegeven op de vraag of apotheekmedewerkers tevreden zijn met hun indeling in het functiewaarderingssysteem. Daarna wordt de achtergrond van de medewerkers beschreven, zoals hun geslacht, leeftijd, gezinssituatie, etniciteit, werkervaring en opleiding. Ten slotte wordt aandacht besteed aan de arbeidsvoorwaarden en loopbaanperspectieven van apotheekmedewerkers. Zijn deze met de invoering van het functiewaarderingssysteem verbeterd?

\subsection{Het nieuwe functiewaarderingssysteem}

Per 1 april 2003 is een nieuw functiewaarderingssysteem in de openbare apotheken ingevoerd. Het scala aan functies aanwezig in de openbare apotheek wordt aan de hand van dit systeem ingedeeld in drie functiecategorieën, te weten (i) management; (ii) primaire processen en direct ondersteunend en (iii) ondersteunend/staf. Functies worden ingedeeld naar de aard van de werkzaamheden en taken. Het nieuwe functiewaarderingssysteem voorziet ook in een nieuwe beloningsstructuur.

De verschillende functies waarin apothekersassistenten ingedeeld zijn, worden weergegeven in tabel 2.1. Van de assistenten is $88 \%$ werkzaam als 'gewone' apothekersassistent. De rest van de assistenten werkt in één van de drie variant-functies die naar aanleiding van het nieuwe functiewaarderingssysteem onderscheiden zijn, te weten: farmaceutische patiëntenzorg $(4 \%)$, coördinerend $(3 \%)$ en kwaliteitszorg ( $2 \%$ ). $3 \%$ van de assistenten (categorie 'anders') is in meer dan één (variant)functie werkzaam, of werkt als farmaceutisch manager of teamleider. Een variantfunctie van apothekersassistent is dan aangevuld met bijvoorbeeld coördinerende werkzaamheden of het bewaken van de uitvoering en de kwaliteit van de processen in de openbare apotheek. Uit het werkgeversonderzoek ${ }^{10}$ bleek al dat slechts $7 \%$ van de apotheken beschikt over apothekersassistenten in de variant farmaceutische patiëntenzorg (FPZ). 13\% van de apotheken heeft apothekersassistenten in de variant coördinerend in dienst en $10 \%$ in de variant kwaliteitszorg.

Naast apothekersassistenten werken er in de openbare apotheek vaak nog andere apotheekmedewerkers, zoals apotheekhulpen, bezorgers, schoonmakers en administratieve krachten die een ondersteunende rol spelen. In dit rapport scharen we al deze medewerkers onder de noemer overige apotheekmedewerkers. Dit zijn medewerkers die geen diploma tot apothekersassistent hebben en die bepaalde taken verrichten die anders door een apothekersassistent uitgevoerd zouden moeten worden. ${ }^{11}$ Door een aantal, meestal relatief eenvoudige, taken van de apothekers-

10. I. Sieben, A. de Grip en M. Hensen, (2004). Apothekers en de openbare apotheek: Arbeidsmarktmonitor Apotheekbranche 2003-2004, ROA-R-2004/4, Maastricht.

11. G.H.M. Evers, M. van Moorsel en H. van der Werff (2001). Functiedifferentiatie binnen de apothekersbranche. Ideaaltypische profielen in kwalitatieve en kwantitatieve zin. IVA, Tilburg. 
assistenten over te nemen, kunnen de gediplomeerde assistenten zich richten op de kerntaken van hun beroep: het bereiden en recepteren van geneesmiddelen en het geven van voorlichting.

Tabel 2.1

Apothekersassistenten in de openbare apotheek volgens het functiewaarderingssysteem, 2004

\begin{tabular}{lr}
\hline & $\%$ \\
\hline & \\
Apothekersassistent & 88 \\
Apothekersassistent variant FPZ & 4 \\
Apothekersassistent variant coördinerend & 3 \\
Apothekersassistent variant kwaliteitszorg & 2 \\
Anders & 3
\end{tabular}

Bron: ROA

Uit tabel 2.2 blijkt dat $29 \%$ van de overige apotheekmedewerkers werkzaam is als apotheekhulp. Deze medewerkers ondersteunen met name het primaire proces. Uit het werkgeversonderzoek ${ }^{12}$ bleek dat $43 \%$ van de apotheken een apotheekhulp in dienst heeft, met name apotheken die in de Randstad gesitueerd zijn. Naast de apotheekhulpen hebben ook de leerling-apothekersassistenten (uitsluitend BBL) (14\%), financieel administratief medewerkers (7\%), administratief secretarieel medewerkers $(6 \%)$, bezorgers $(21 \%)$ en schoonmakers $(13 \%)$ een plek gekregen in het nieuwe functiewaarderingssysteem. De categorie 'overig' (10\%) bestaat onder andere uit medewerkers die meerdere functies hebben, bijvoorbeeld schoonmaker en bezorger zijn.

Tabel 2.2

Overige medewerkers in de openbare apotheek volgens het functiewaarderingssysteem, 2004

\begin{tabular}{lr}
\hline & $\%$ \\
\hline & $\%$ \\
Algemeen ondersteunend medewerker/apotheekhulp & 29 \\
Leerling apothekersassistent (uitsluitend BBL) & 14 \\
Financieel administratief medewerker & 7 \\
Administratief secretarieel medewerker & 6 \\
Bezorger & 21 \\
Schoonmaker & 13 \\
Overig & 10 \\
\hline
\end{tabular}

Bron: ROA

Zijn de apotheekmedewerkers tevreden met hun functie-indeling in het nieuwe functiewaarderingssysteem? Uit tabel 2.3 komt naar voren dat een grote meerderheid van de apothekersassistenten wel tevreden is. $18 \%$ van de 'gewone' apothekersassistenten is echter niet zo tevreden over de indeling van hun functie en $3 \%$ is helemaal niet tevreden. Wellicht waren zij liever in één van de variant-functies ingedeeld. De apothekersassistenten in de variant kwaliteitszorg en in de variant

12. I. Sieben, A. de Grip en M. Hensen (2004). Apothekers en de openbare apotheek: Arbeidsmarktmonitor Apotheekbranche 2003, ROA-R-2004/4, Maastricht. 
coördinerend zijn juist zeer tevreden over hun indeling. De hogere inschaling van deze assistenten speelt hierbij waarschijnlijk een rol.

Tabel 2.3

Tevredenheid met de functie-indeling in het functiewaarderingssysteem, 2004

\begin{tabular}{|c|c|c|c|c|}
\hline & $\begin{array}{c}\begin{array}{c}\text { Zeer } \\
\text { tevreden }\end{array} \\
\%\end{array}$ & $\begin{array}{c}\text { Wel } \\
\text { tevreden } \\
\%\end{array}$ & $\begin{array}{c}\text { Niet zo } \\
\text { tevreden } \\
\%\end{array}$ & $\begin{array}{c}\text { Helemaal } \\
\text { niet } \\
\text { tevreden } \\
\%\end{array}$ \\
\hline \multicolumn{5}{|l|}{ Apothekersassistenten } \\
\hline Apothekersassistent & 3 & 76 & 18 & 3 \\
\hline Apothekersassistent variant FPZ & 14 & 67 & 18 & 1 \\
\hline Apothekersassistent variant coördinerend & 10 & 80 & 9 & 1 \\
\hline Apothekersassistent variant kwaliteitszorg & 12 & 82 & 4 & 2 \\
\hline Anders & 19 & 67 & $\begin{array}{r}4 \\
12\end{array}$ & 2 \\
\hline \multicolumn{5}{|l|}{ Overige medewerkers } \\
\hline Apotheekhulp & 7 & 79 & 11 & 3 \\
\hline Leerling apothekersassistent (uitsluitend BBL) & 5 & 76 & 18 & 1 \\
\hline Financieel administratief medewerker & 14 & 69 & 7 & 0 \\
\hline Administratief secretarieel medewerker & 1 & 80 & 14 & 5 \\
\hline Bezorger & 13 & 76 & 9 & 2 \\
\hline Schoonmaker & 9 & 83 & 5 & 3 \\
\hline Overig & 8 & 74 & 16 & 5 \\
\hline
\end{tabular}

Bron: ROA

Van de overige apotheekmedewerkers zijn de BBL'ers en de administratief secretarieel medewerkers het minst tevreden (19\%). Financieel administratief medewerkers en schoonmakers daarentegen zijn doorgaans wel tevreden over de indeling van hun functie volgens het functiewaarderingssysteem.

\subsection{De achtergrond van apotheekmedewerkers}

\section{Geslacht en leeftijd}

Tabel 2.4 maakt duidelijk dat het beroep van apothekersassistent nog steeds een echt vrouwenberoep is. Minder dan 1\% van de assistenten werkzaam in de openbare apotheek is een man. Dit geldt ook voor de variant-assistenten, al zijn apothekersassistenten werkzaam in de variant coördinerend wat vaker een man (2\%). Ook bij de overige apotheekmedewerkers is het merendeel vrouw. De functie van bezorger wordt echter wel vaak door mannen (58\%) vervuld.

Tabel 2.4 geeft ook de gemiddelde leeftijd van de medewerkers in de openbare apotheek. Apothekersassistenten zijn gemiddeld 36,9 jaar. In 2001 was de gemiddelde leeftijd nog 35,6 jaar. De apothekersassistenten in een variant-functie zijn gemiddeld een jaar ouder dan de 'gewone' apothekersassistenten. Zo zijn assistenten werkzaam in de variant farmaceutische patiëntenzorg gemiddeld 38,4 jaar. De gemiddelde leeftijd van de overige medewerkers is met 42 jaar beduidend hoger dan de gemiddelde leeftijd van de apothekersassistenten. Binnen de groep overige 
apotheekmedewerkers zijn de BBL'ers de jongsten met een gemiddelde leeftijd van 32 jaar $^{13}$, terwijl schoonmakers de oudsten zijn met gemiddeld 48 jaar.

Tabel 2.4

Geslacht en gemiddelde leeftijd van apotheekmedewerkers, 2004

\begin{tabular}{lcc}
\hline & $\begin{array}{c}\text { Percentage } \\
\text { man }\end{array}$ & $\begin{array}{c}\text { Gemiddelde leeftijd } \\
\text { (in jaren) }\end{array}$ \\
\hline Apothekersassistent & 0,4 & 36,9 \\
Variant-apothekersassistent & 1,0 & 38,0 \\
BBL'er & 1,4 & 31,8 \\
Apotheekhulp & 6,9 & 40,6 \\
Administratief en secretarieel medewerker & 1,5 & 41,6 \\
Bezorger & 57,7 & 47,0 \\
Schoonmaker & 0,7 & 48,2 \\
\hline
\end{tabular}

Bron: ROA

Figuur 2.1 geeft een overzicht van de leeftijdsverdeling van de apotheekmedewerkers. De meeste apothekersassistenten zijn tussen de 25 en 30 jaar. Er zijn vrij weinig oudere assistenten; slechts $13 \%$ van de apothekersassistenten is ouder dan 50 jaar. In 2001 was het aandeel ouderen echter beduidend lager dan nu. De meeste overige apotheekmedewerkers zijn tussen de 45 en 50 jaar. Het is opvallend dat er vrij veel oudere overige apotheekmedewerkers zijn; ruim $25 \%$ van deze medewerkers is ouder dan 50 jaar.

Figuur 2.1

Leeftijdsopbouw van apothekersassistenten en overige apotheekmedewerkers, 2004

$\%$

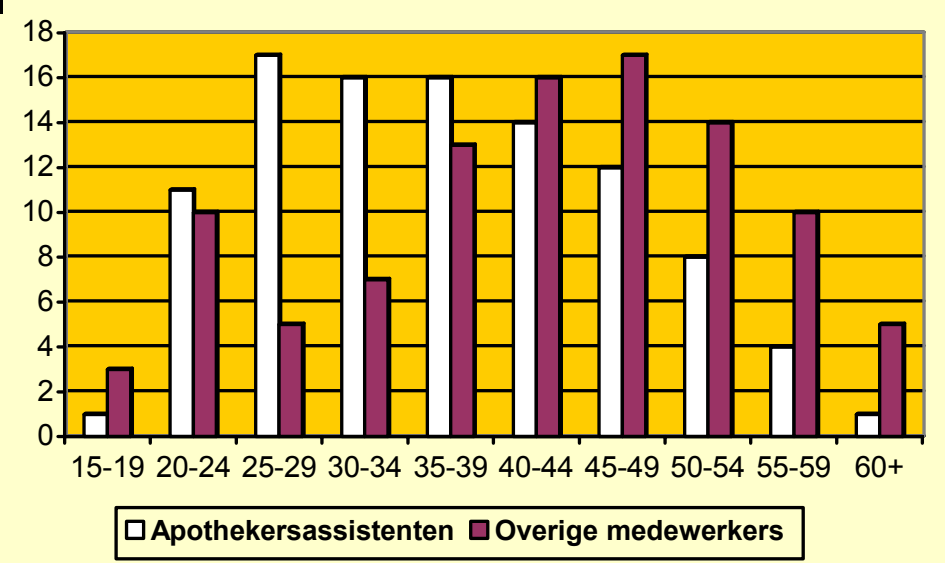

Bron: ROA

13. BBL'ers blijken niet alleen maar jonge leerlingen te zijn; $21 \%$ is ouder dan 40 jaar. 


\section{Gezinssituatie}

Wat is de gezinssituatie van de medewerkers die in de openbare apotheek werkzaam zijn? Tabel 2.5 geeft aan dat de meerderheid van de apotheekmedewerkers een partner heeft. Het blijkt dat met name schoonmakers, 'gewone' apothekersassistenten en de administratief en secretarieel medewerkers vaak een partner hebben. BBL'ers hebben het vaakst geen partner (36\%). De gemiddeld relatief lage leeftijd van deze groep medewerkers zou hier een verklaring voor kunnen zijn.

Tabel 2.5

Gezinssituatie van apotheekmedewerkers, 2004

\begin{tabular}{lcc}
\hline & $\begin{array}{c}\text { Partner } \\
\%\end{array}$ & $\begin{array}{c}\text { Thuiswonende kinderen } \\
\%\end{array}$ \\
\hline Apothekersassistent & 81 & 57 \\
Variant-apothekersassistent & 76 & 47 \\
BBL'er & 64 & 37 \\
Apotheekhulp & 75 & 58 \\
Administratief en secretarieel medewerker & 81 & 65 \\
Bezorger & 76 & 41 \\
Schoonmaker & 88 & 55 \\
\hline
\end{tabular}

Bron: ROA

Tabel 2.5 laat tevens zien dat de BBL'ers het minst vaak thuiswonende kinderen hebben $(37 \%)$. Administratief en secretariële medewerkers hebben het vaakst thuiswonende kinderen (65\%). Apotheekmedewerkers zonder partner hebben meestal geen thuiswonende kinderen. Het is opvallend dat in 2001 slechts $49 \%$ van de apothekersassistenten één of meer thuiswonende kinderen had, terwijl dit tegenwoordig $57 \%$ van de apothekersassistenten is. Dit duidt erop dat het werk in de openbare apotheek voor veel assistenten goed te combineren is met de zorg voor kinderen.

Tabel 2.6

Leeftijd jongste thuiswonend kind, 2004

\begin{tabular}{lrrrrr}
\hline & $\begin{array}{c}0-2 \\
\text { jaar } \\
\%\end{array}$ & $\begin{array}{c}3-4 \\
\text { jaar } \\
\%\end{array}$ & $\begin{array}{c}5-9 \\
\text { jaar } \\
\%\end{array}$ & $\begin{array}{c}10-14 \\
\text { jaar } \\
\%\end{array}$ & $\begin{array}{c}15 \text { jaar } \\
\text { en ouder } \\
\%\end{array}$ \\
\hline Apothekersassistent & 27 & 11 & 24 & 18 & 20 \\
Variant-apothekersassistent & 28 & 17 & 17 & 17 & 21 \\
BBL'er & 9 & 9 & 19 & 37 & 26 \\
Apotheekhulp & 11 & 5 & 13 & 27 & 44 \\
Administratief en secretarieel medewerker & 14 & 12 & 19 & 32 & 23 \\
Bezorger & 3 & 6 & 13 & 19 & 59 \\
Schoonmaker & 1 & 4 & 17 & 27 & 51
\end{tabular}

Bron: ROA

Vergeleken met 2001 is niet alleen het percentage assistenten dat thuiswonende kinderen heeft, maar ook het aandeel assistenten dat de zorg draagt voor een jong kind toegenomen. Tabel 2.6 geeft aan dat $40 \%$ van de assistenten met thuiswonende kinderen een kind heeft dat jonger is dan 4 jaar. $24 \%$ van de apothekers- 
assistenten met thuiswonende kinderen heeft een kind tussen 5 en 9 jaar. Ook dit duidt erop dat de combinatie zorg en werk goed verloopt. De gemiddeld hogere leeftijd van de overige apotheekmedewerkers heeft zijn weerslag op de gemiddelde leeftijd van hun jongste thuiswonende kinderen. Zo blijken de overige apotheekmedewerkers met name de zorg te dragen voor een kind dat ouder is dan 10 jaar.

\section{Etniciteit}

Tabel 2.7 laat zien dat de meeste apotheekmedewerkers doorgaans de Nederlandse nationaliteit hebben. Schoonmakers en apotheekhulpen zijn wat vaker uit een andere bevolkingsgroep afkomstig. Zo is 3 à $4 \%$ van hen van Surinaamse afkomst. Opvallend is dat relatief veel BBL'ers (15\%) van niet-Nederlandse afkomst zijn. Wanneer deze groep later in de openbare apotheek gaat werken, dan betekent dit dat het aantal allochtone assistenten in de toekomst zal toenemen, waardoor er een betere afspiegeling met de cliënten in de openbare apotheek zal zijn.

Tabel 2.7

Etniciteit van apotheekmedewerkers, 2004

\begin{tabular}{|c|c|c|c|c|c|c|}
\hline & $\begin{array}{c}\text { Neder- } \\
\text { lands } \\
\%\end{array}$ & $\begin{array}{c}\begin{array}{c}\text { Suri- } \\
\text { naams }\end{array} \\
\%\end{array}$ & $\begin{array}{c}\text { Arubaans } \\
\text { of } \\
\text { Antilliaans } \\
\%\end{array}$ & Turks & $\begin{array}{c}\text { Marok- } \\
\text { kaans } \\
\%\end{array}$ & $\begin{array}{c}\text { Andere } \\
\text { bevolkings- } \\
\text { groep } \\
\%\end{array}$ \\
\hline Apothekersassistent & 97 & 1 & . & 1 & & 1 \\
\hline Variant-assistent & 96 & 2 & & 1 & 1 & \\
\hline BBL'er & 85 & 1 & 1 & 1 & 1 & 11 \\
\hline $\begin{array}{l}\text { Apotheekhulp } \\
\text { Administratief en }\end{array}$ & 94 & 3 & 0 & 0 & 1 & 3 \\
\hline secretarieel medewerker & 98 & & . & 1 & . & 1 \\
\hline Bezorger & 97 & 1 & . & 1 & . & 1 \\
\hline Schoonmaker & 90 & 4 & . & . & . & 6 \\
\hline
\end{tabular}

\subsection{Werkervaring en opleiding}

Figuur 2.2 geeft een beeld van de werkervaring van apotheekmedewerkers. Gemiddeld genomen heeft een medewerker bijna 17 jaar werkervaring, zowel binnen als buiten de openbare apotheek. Wanneer we deze totale werkervaring wat nader bekijken, dan blijkt dat met name bezorgers, met gemiddeld 23 jaar, veel werkervaring hebben. Daarnaast blijkt een apothekersassistent in een variant-functie over meer werkervaring te beschikken dan een 'gewone' apothekersassistent (gemiddeld 18 jaar ten opzichte van 16 jaar).

De werkervaring binnen de openbare apotheek is met name voor de apothekersassistenten van belang. Assistenten in een variant-functie werken gemiddeld genomen langer in de sector (gemiddeld 17 jaar) dan 'gewone' assistenten (gemiddeld 14 jaar). Vooral assistenten in de variant coördinerend zijn met gemiddeld 18 jaar het langst werkzaam in de openbare apotheek. Dit duidt erop dat de variantapothekersassistenten zeer ervaren medewerkers zijn. 
Figuur 2.2

Totale werkervaring binnen en buiten de openbare apotheek, 2004

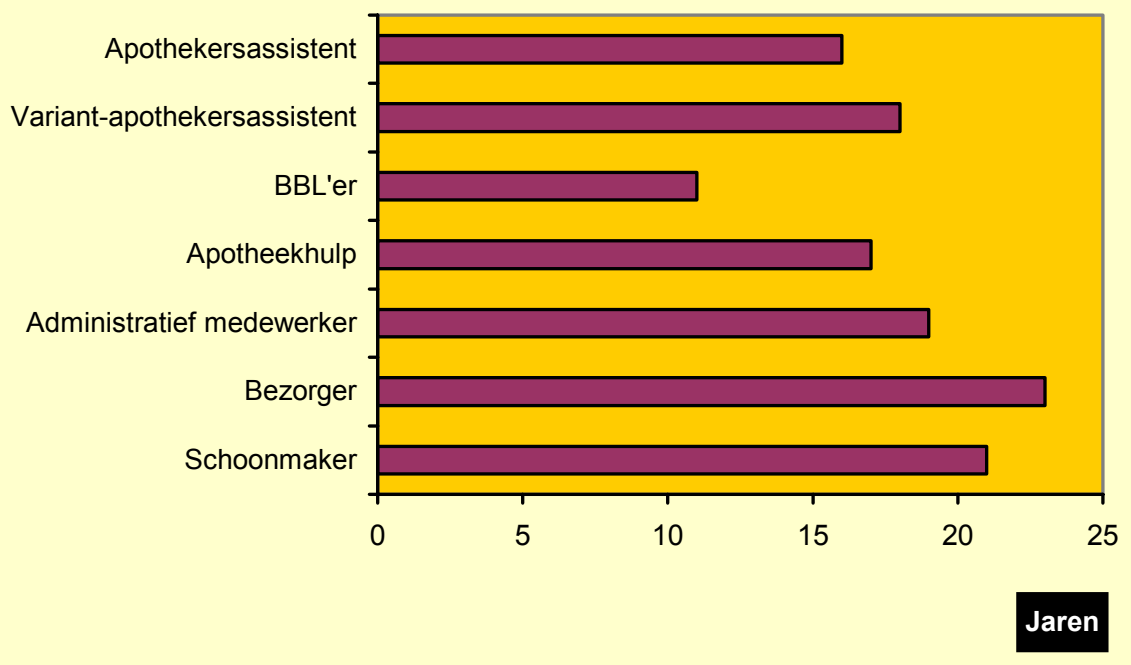

Bron: ROA

Hoe lang apotheekmedewerkers al in de huidige apotheek werkzaam zijn, wordt weergegeven in tabel 2.8. Uit deze tabel blijkt dat $40 \%$ van de 'gewone' apothekersassistenten minder dan 5 jaar in de huidige openbare apotheek werkt. De gemiddelde baanduur van assistenten is overigens 8 jaar. In 2001 werkten assistenten ook gemiddeld 8 jaar in dezelfde apotheek. Assistenten in een variant-functie zijn aanmerkelijk langer in de huidige apotheek werkzaam, gemiddeld zo'n 11 jaar. Blijkbaar zijn met name de assistenten die al lang in de apotheek werkzaam zijn, met de invoering van het functiewaarderingssysteem tot variant-assistent gepromo-veerd. BBL'ers werken minder dan 5 jaar in de huidige apotheek, hetgeen niet zo vreemd is aangezien zij een opleiding volgen. Ook de apotheekhulpen en de administratief en secretariële medewerkers werken doorgaans minder dan 5 jaar in de huidige openbare apotheek.

Tabel 2.8

Aantal jaren werkzaam in huidige apotheek, 2004

\begin{tabular}{|c|c|c|c|c|c|}
\hline & $\begin{array}{c}<5 \\
\text { jaar } \\
\%\end{array}$ & $\begin{array}{c}5-10 \\
\text { jaar } \\
\%\end{array}$ & $\begin{array}{c}10-15 \\
\text { jaar } \\
\%\end{array}$ & $\begin{array}{c}15-20 \\
\text { jaar } \\
\%\end{array}$ & $\begin{array}{c}>20 \text { jaar } \\
\%\end{array}$ \\
\hline Apothekersassistent & 40 & 21 & 17 & 11 & 11 \\
\hline $\begin{array}{l}\text { Variant-apothekersassistent } \\
\text { BBL'er }\end{array}$ & 19 & 25 & 25 & 14 & 17 \\
\hline $\begin{array}{l}\text { BBL'er } \\
\text { Apotheekhulp }\end{array}$ & $\begin{array}{r}100 \\
64\end{array}$ & $1 \overline{9}$ & 7 & 5 & 5 \\
\hline Administratief en secretarieel medewerker & 56 & 19 & 8 & 4 & 13 \\
\hline Bezorger & 48 & 32 & 9 & 6 & 5 \\
\hline Schoonmaker & 29 & 21 & 24 & 11 & 15 \\
\hline
\end{tabular}

Bron: ROA 


\section{Herintreders en schoolverlaters}

Herintreders zijn apotheekmedewerkers die na hun opleiding een tijd gewerkt hebben, daarna met werken gestopt zijn om zorgtaken op zich te nemen, om vervolgens weer in de openbare apotheek te gaan werken. Uit tabel 2.9 blijkt dat $20 \%$ van de 'gewone' apothekersassistenten aangeeft de afgelopen jaren te zijn heringetreden. In 2001 was dit nog 16\%. Ruim 51\% van deze herintreders heeft de loopbaan voor 10 jaar of minder onderbroken. Apothekersassistenten in een variantfunctie daarentegen onderbreken hun loopbaan veel minder snel; slechts $10 \%$ van deze assistenten is de afgelopen jaren heringetreden. Van de overige medewerkers in de openbare apotheek blijkt gemiddeld $16 \%$ de afgelopen jaren te zijn heringetreden. Met name administratief en secretariële medewerkers (20\%) en apotheekhulpen (18\%) zijn de afgelopen jaren heringetreden. Ook hier duurt de onderbreking voor $49 \%$ van de herintreders gemiddeld korter dan 10 jaar. De administratief en secretariële medewerkers onderbreken hun loopbaan met gemiddeld 7 jaar het kortst van alle apotheekmedewerkers.

Tabel 2.9

Herintreders en schoolverlaters, 2004

\begin{tabular}{lccr}
\hline & $\begin{array}{c}\text { Herintreder } \\
\%\end{array}$ & $\begin{array}{c}\text { Aantal jaren } \\
\text { eruit geweest }\end{array}$ & $\begin{array}{c}\text { Schoolverlater } \\
\%\end{array}$ \\
\hline Apothekersassistent & 20 & 11 & 9 \\
Variant-apothekersassistent & 10 & 9 & 2 \\
BBL'er & - & - & - \\
Apotheekhulp & 18 & 12 & 12 \\
Administratief en secretarieel medewerker & 20 & 14 & 5 \\
Bezorger & 13 & 12 & 1 \\
Schoonmaker & 16 & & \\
\hline
\end{tabular}

$-=$ niet berekend

Bron: ROA

Het percentage apotheekmedewerkers dat recentelijk zijn of haar opleiding heeft afgerond wordt weergegeven in de laatste kolom van tabel 2.9. We spreken hier van schoolverlaters wanneer medewerkers minder dan 3 jaar geleden hun opleiding hebben afgesloten. Het blijkt dat $9 \%$ van de apothekersassistenten werkzaam in de openbare apotheek net van school komt. Dit is ongeveer net zoveel als in 2001, toen het percentage schoolverlaters $8 \%$ bedroeg. Apothekersassistenten in een variantfunctie zijn zelden schoolverlater (2\%). Administratief en secretariële medewerkers $(12 \%)$ en apotheekhulpen $(11 \%)$ zijn wel betrekkelijk vaak schoolverlaters, terwijl slechts $1 \%$ van de schoonmakers net een opleiding afgerond heeft.

\section{Opleiding}

Alle apothekersassistenten hebben uiteraard dezelfde scholing genoten, namelijk de MBO-opleiding tot apothekersassistent. Voor de overige medewerkers verschillen de genoten opleidingen echter in niveau en richting. Tabel 2.10 geeft een overzicht van de verschillende opleidingsniveaus die de apotheekmedewerkers hebben afgerond. De meerderheid van de overige apotheekmedewerkers heeft een opleiding op VMBO 
of MAVO niveau afgerond. Alleen de administratieve en secretariële medewerkers hebben relatief vaak een opleiding op MBO niveau afgerond. Medewerkers met alleen basisonderwijs als hoogst voltooide opleiding zijn met name te vinden in beroepen als bezorger en schoonmaker.

Tabel 2.10

Hoogst voltooide opleidingsniveau van overige apotheekmedewerkers, 2004

\begin{tabular}{lcccc}
\hline & Apotheekhulp & $\begin{array}{c}\text { Administratief } \\
\text { en secretarieel } \\
\text { medewerker } \\
\%\end{array}$ & Bezorger & Schoonmaker \\
& $\%$ & $\%$ & $\%$ \\
\hline Basisonderwijs & 4 & 0 & 13 & 14 \\
VMBO/MAVO & 51 & 29 & 54 & 74 \\
HAVO/VWO & 11 & 20 & 12 & 2 \\
MBO & 27 & 39 & 16 & 8 \\
HBO & 5 & 10 & 4 & 2 \\
Universiteit & 2 & 2 & 1 & 0 \\
\hline
\end{tabular}

Bron: ROA

Tabel 2.11 geeft een overzicht van de opleidingsrichtingen van de overige apotheekmedewerkers. De meeste medewerkers hebben een algemene opleiding (bijvoorbeeld MAVO) afgerond. Apotheekhulpen hebben relatief vaak een opleiding in de paramedische en farmaceutische richting genoten. Zoals verwacht mocht worden, heeft $26 \%$ van de administratieve en secretariële medewerkers een opleiding in de economische en administratieve richtingen afgerond. Bezorgers hebben vaak een technische achtergrond.

Tabel 2.11

Opleidingsrichting van overige apotheekmedewerkers, 2004

\begin{tabular}{|c|c|c|c|c|}
\hline & $\begin{array}{c}\text { Apotheekhulp } \\
\text { \% }\end{array}$ & $\begin{array}{c}\text { Administratief } \\
\text { en secretarieel } \\
\text { medewerker } \\
\%\end{array}$ & $\begin{array}{c}\text { Bezorger } \\
\\
\%\end{array}$ & $\begin{array}{c}\text { Schoonmaker } \\
\%\end{array}$ \\
\hline $\begin{array}{l}\text { Algemeen } \\
\text { Farmaceutisch } \\
\text { Paramedisch } \\
\text { Economie en administratie } \\
\text { Sociaal-cultureel } \\
\text { Techniek } \\
\text { Onderwijs } \\
\text { Anders }\end{array}$ & $\begin{array}{r}58 \\
8 \\
13 \\
6 \\
2 \\
3 \\
2 \\
2 \\
13\end{array}$ & $\begin{array}{r}44 \\
12 \\
10 \\
26 \\
1 \\
3 \\
1 \\
10\end{array}$ & $\begin{array}{r}56 \\
1 \\
2 \\
6 \\
3 \\
18 \\
3 \\
14\end{array}$ & $\begin{array}{r}62 \\
0 \\
3 \\
7 \\
0 \\
2 \\
2 \\
22\end{array}$ \\
\hline
\end{tabular}

Bron: ROA

De aansluiting tussen opleiding en werk wordt door de apotheekmedewerkers doorgaans goed bevonden (zie tabel 2.12). Zo is $44 \%$ van de 'gewone' en variant-assistenten van mening dat de aansluiting goed tot uitstekend is. Meer dan $15 \%$ van de assistenten vindt de aansluiting tussen opleiding en werk echter matig tot slecht. Dit zijn met name de niet-schoolverlaters, dus de assistenten die al langer dan 3 jaar in een openbare apotheek werken. Opvallend is verder dat bezorgers en schoonmakers de aansluiting tussen opleiding en werk vaak uitstekend of goed vinden. 
Toch vindt nog 12 tot $18 \%$ van de overige apotheekmedewerkers hun aansluiting doorgaans matig tot slecht.

Tabel 2.12

Beoordeling van de aansluiting tussen opleiding en werk, 2004

\begin{tabular}{lccccc}
\hline & $\begin{array}{c}\text { Uitstekend } \\
\%\end{array}$ & $\begin{array}{c}\text { Goed } \\
\%\end{array}$ & $\begin{array}{c}\text { Voldoende } \\
\%\end{array}$ & $\begin{array}{c}\text { Matig } \\
\%\end{array}$ & $\begin{array}{c}\text { Slecht } \\
\%\end{array}$ \\
\hline $\begin{array}{l}\text { Apothekersassistent } \\
\text { Variant-apothekersassistent }\end{array}$ & 3 & 41 & 37 & 15 & 4 \\
$\begin{array}{l}\text { BBL'er } \\
\text { Apotheekhulp }\end{array}$ & 2 & 42 & 40 & 13 & 3 \\
$\begin{array}{l}\text { Administratief en secretarieel } \\
\text { medewerker }\end{array}$ & 4 & 35 & 44 & 12 & 5 \\
$\begin{array}{l}\text { Bezorger } \\
\text { Schoonmaker }\end{array}$ & 4 & 35 & 43 & 10 & 8 \\
& 14 & 38 & 41 & 11 & 4 \\
& 15 & 41 & 30 & 5 & 10 \\
\hline
\end{tabular}

Bron: ROA

Leerling-apothekersassistenten in de BBL

In deze paragraaf wordt speciale aandacht besteed aan de leerling-apothekersassistenten in de beroepsbegeleidende leerweg (BBL). Deze assistenten in opleiding zijn vier dagen per week werkzaam in een apotheek en gaan één dag in de week naar school. De aansluiting tussen opleiding en werk is voor deze medewerkers van groot belang. Figuur 2.3 laat zien dat $42 \%$ van de BBL'ers de aansluiting als uitstekend of goed beoordeelt en dat $37 \%$ de aansluiting voldoende vindt.

Figuur 2.3

Beoordeling door BBL'ers van de aansluiting tussen de BBL-opleiding en het huidige werk in de openbare apotheek, 2004

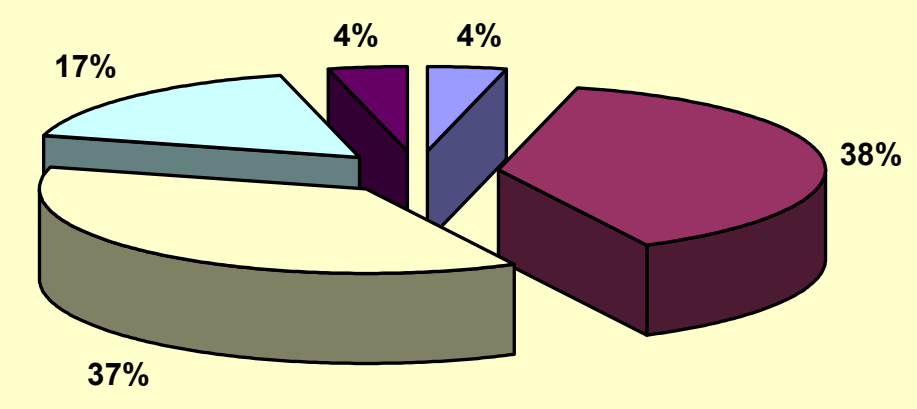
口Uitstekend
$\square$ Goed
$\square$ Voldoende
$\square$ Matig
$\square$ Slecht

Bron: ROA 
Uit het werkgeversonderzoek ${ }^{14}$ bleek hoe apothekers de aansluiting tussen de opleiding tot apothekersassistent en het werk voor assistenten in hun apotheek zien. De meeste apothekers (56\%) vinden deze aansluiting voldoende, terwijl ongeveer eenderde van de apothekers de aansluiting als goed of uitstekend beoordeelt. Daar staat tegenover dat $13 \%$ van de apothekers de aansluiting tussen school en werk matig tot slecht noemt. BBL'ers vinden de aansluiting tussen de opleiding en het huidige werk doorgaans slechter. Zo beoordeelt $21 \%$ de aansluiting als matig tot slecht, terwijl slechts $13 \%$ van de apothekers een dergelijke beoordeling geeft. Blijkbaar zijn er bepaalde aspecten, bijvoorbeeld de begeleiding vanuit het ROC, waar apothekers doorgaans minder mee te maken hebben dan BBL'ers waardoor hun beoordeling positiever uitvalt.

Ook de begeleiding in de apotheek en vanuit het ROC (opleidingsinstelling) speelt een belangrijke rol. Tabel 2.13 laat zien dat BBL'ers met name niet tevreden zijn over de begeleiding vanuit het $\operatorname{ROC}(50 \%)$. De begeleiding vanuit de apotheek wordt daarentegen doorgaans goed beoordeeld door de BBL'ers. De aansluiting tussen de opleiding en de praktijk verloopt waarschijnlijk door de gebrekkige begeleiding vanuit de ROC's niet zo goed, waardoor $37 \%$ van de BBL'ers (helemaal) niet tevreden is over deze aansluiting.

Tabel 2.13

Tevredenheid van BBL'ers met de begeleiding, 2004

\begin{tabular}{lcccc}
\hline & $\begin{array}{c}\text { Zeer } \\
\text { tevreden } \\
\%\end{array}$ & $\begin{array}{c}\text { Wel } \\
\text { tevreden } \\
\%\end{array}$ & $\begin{array}{c}\text { Niet zo } \\
\text { tevreden } \\
\%\end{array}$ & $\begin{array}{c}\text { Helemaal niet } \\
\text { tevreden } \\
\%\end{array}$ \\
\hline Begeleiding in de apotheek & 35 & 52 & 11 & 2 \\
Begeleiding vanuit het ROC & 1 & 49 & 41 & 9 \\
Aansluiting school-praktijk & 6 & 56 & 29 & 9 \\
\hline
\end{tabular}

\section{Bron: ROA}

\subsection{Verbeterde arbeidsvoorwaarden?}

In deze paragraaf staan twee vragen centraal: Zijn met de invoering van het functiewaarderingssysteem de arbeidsvoorwaarden in de openbare apotheek verbeterd? En zijn er grote verschillen in arbeidsvoorwaarden tussen de verschillende functies?

\section{Arbeidscontract}

Tabel 2.14 laat zien dat veel apotheekmedewerkers een vast contract hebben. Met name de apothekersassistenten die in een variant-functie werkzaam zijn (98\%) en schoonmakers $(95 \%)$ hebben vaak een vast contract. De jongere apotheekmedewerkers en de medewerkers met weinig werkervaring zijn vaker volgens een tijdelijk contract werkzaam. $47 \%$ van de BBL'ers heeft een tijdelijk contract met uitzicht op een vast contract. Overigens hebben apothekersassistenten tegenwoordig minder

14. I. Sieben, A. de Grip en M. Hensen, (2004). Apothekers en de openbare apotheek: Arbeidsmarktmonitor Apotheekbranche 2003-2004, ROA-R-2004/4, Maastricht. 
vaak een vast contract en vaker een tijdelijk contract met uitzicht op een vast contract dan in 2001. Wellicht maakt de huidige economische en politieke situatie de apothekers voorzichtiger in het aanbieden van vaste contracten.

Tabel 2.14

Arbeidscontract van apotheekmedewerkers, 2004

\begin{tabular}{lcccc}
\hline & $\begin{array}{c}\text { Vast } \\
\text { contract } \\
\%\end{array}$ & $\begin{array}{c}\text { Tijdelijk (met } \\
\text { uitzicht op } \\
\text { vast) } \\
\%\end{array}$ & $\begin{array}{c}\text { Tijdelijk } \\
\text { (zonder } \\
\text { uitzicht) } \\
\%\end{array}$ & $\begin{array}{c}\text { Uitzend- } \\
\text { of } \\
\text { oproep- } \\
\text { contract } \\
\%\end{array}$ \\
\hline $\begin{array}{l}\text { Apothekersassistent } \\
\text { Variant-apothekersassistent }\end{array}$ & 94 & 4 & 1 & 1 \\
BBL'er & 98 & 2 & 0 & 0 \\
Apotheekhulp & 43 & 47 & 10 & 0 \\
Administratief en secretarieel medewerker & 81 & 12 & 4 & 3 \\
Bezorger & 91 & 7 & 1 & 1 \\
Schoonmaker & 86 & 5 & 3 & 6 \\
& 95 & 4 & 0 & 1 \\
\hline
\end{tabular}

Bron: ROA

\section{Werkuren}

Uit tabel 2.15 blijkt dat er een grote diversiteit is in het aantal werkuren van apotheekmedewerkers binnen de openbare apotheek. Zo werkt de helft van de variant-apothekersassistenten meer dan 32 uur per week; voor de 'gewone' assistenten is dit percentage maar $35 \%$. Met name de assistenten in de variant-functie coördinerend werken vaak meer dan 32 uur per week. Assistenten werkzaam in de variant farmaceutische patiëntenzorg daarentegen werken vaak tussen de 24 en 32 uur per week. Apotheekhulpen en administratief en secretariële medewerkers werken doorgaans tussen de 16 en 24 werkuren per week. Bezorgers en met name schoonmakers werken vaak in nog kleinere deeltijdbanen.

Tabel 2.15

Aantal feitelijke werkuren van apotheekmedewerkers in de openbare apotheek, 2004

\begin{tabular}{lrrrr}
\hline & $<16$ & $16-24$ & $24-32$ & $>32$ \\
\hline Apothekersassistent & & & & \\
Variant-apothekersassistent & 6 & 39 & 20 & 35 \\
BBL'er & 3 & 25 & 22 & 50 \\
Apotheekhulp & 5 & 23 & 47 & 25 \\
Administratief en secretarieel medewerker & 22 & 33 & 20 & 25 \\
Bezorger & 29 & 42 & 17 & 12 \\
Schoonmaker & 43 & 22 & 13 & 19 \\
& 70 & 22 & 7 & 1 \\
\hline
\end{tabular}

Bron: ROA

Tabel 2.16 laat zien dat apothekersassistenten feitelijk meer uren per week werken dan dat ze het liefst zouden willen. Zo werken 'gewone' apothekersassistenten gemiddeld 25,2 uur per week, terwijl ze het liefst gemiddeld 24,4 uur zouden willen werken. Ook de apothekersassistenten met een variant-functie zouden liever wat minder willen werken. Vergeleken met 2001 werken apothekersassistenten overi- 
gens tegenwoordig al 1,2 uren minder per week. Voor de overige apotheekmedewerkers geldt trouwens het tegenovergestelde; deze medewerkers zouden graag meer uren willen werken dan het feitelijke aantal werkuren per week. Met name de BBL'ers zouden het liefst meer uren willen werken, gemiddeld zo'n 2,4 uur per week meer.

Tabel 2.16

Gemiddeld aantal feitelijke en gewenste werkuren van apotheekmedewerkers, 2004

\begin{tabular}{lcc}
\hline & $\begin{array}{c}\text { Gemiddelde feitelijke } \\
\text { werkuren }\end{array}$ & $\begin{array}{c}\text { Gemiddelde gewenste } \\
\text { werkuren }\end{array}$ \\
\hline Apothekersassistent & 25,2 & 24,4 \\
Variant-apothekersassistent & 28,5 & 27,4 \\
BBL'er & 25,7 & 28,1 \\
Apotheekhulp & 22,5 & 23,1 \\
Administratief en secretarieel medewerker & 19,9 & 20,6 \\
Bezorger & 20,2 & 21,7 \\
Schoonmaker & 14,2 & 16,5 \\
\hline
\end{tabular}

Bron: ROA

\section{Werktijden}

Tabel 2.17 geeft een overzicht van de diensten die in de openbare apotheek voorkomen. Het gaat dan om dag-, avond-, nacht-, zondag-, aanwezigheids- en bereikbaarheidsdiensten. Het blijkt dat met name apothekersassistenten avond-, nacht-, zondag-, aanwezigheids- en bereikbaarheidsdiensten draaien. De overige medewerkers werken doorgaans in dagdiensten. Wel werken de bezorgers relatief vaak in de avonden en in aanwezigheidsdiensten.

Tabel 2.17

Diensten in de openbare apotheek, 2004

\begin{tabular}{|c|c|c|c|c|c|c|c|}
\hline & $\begin{array}{c}\text { Dag } \\
\%\end{array}$ & $\begin{array}{c}\text { Avond } \\
\text { \% }\end{array}$ & $\begin{array}{c}\text { Nacht } \\
\%\end{array}$ & $\begin{array}{c}\text { Zon- } \\
\text { dag } \\
\%\end{array}$ & $\begin{array}{c}\text { Aanwezig- } \\
\text { heid } \\
\%\end{array}$ & $\begin{array}{c}\text { Bereik- } \\
\text { baarheid } \\
\%\end{array}$ & $\begin{array}{c}\text { Wisse- } \\
\text { lend } \\
\text { rooster } \\
\%\end{array}$ \\
\hline Apothekersassistent & 96 & 45 & 24 & 45 & 26 & 16 & 23 \\
\hline Variant-assistent & 97 & 53 & 29 & 54 & 30 & 13 & 27 \\
\hline BBL'er & 97 & 5 & 1 & 3 & 2 & 0 & 16 \\
\hline Apotheekhulp & 96 & 7 & 3 & 6 & 3 & 2 & 12 \\
\hline Administratief en & & & & & & & \\
\hline secretarieel medew. & 94 & 4 & 2 & 7 & 3 & 2 & 11 \\
\hline Bezorger & 86 & 15 & 0 & 1 & 6 & 3 & 8 \\
\hline Schoonmaker & 85 & 11 & 1 & 0 & 2 & 1 & 5 \\
\hline
\end{tabular}

Bron: ROA

De laatste kolom van tabel 2.17 laat zien dat ongeveer een kwart van de apothekersassistenten een wisselend rooster heeft. De overige apotheekmedewerkers werkt meestal volgens een vast rooster. 
Wat verdienen apotheekmedewerkers die werkzaam zijn in de openbare apotheek? Tabel 2.18 geeft aan dat het bruto maandsalaris bij een 36-urige werkweek gemiddeld het hoogst is voor apothekersassistenten die een variant-functie hebben: $€ 2.177,-$. De 'gewone' apothekersassistenten krijgen gemiddeld $€ 2$ 2.013,- per maand. De BBL'ers verdienen het minste per maand, namelijk $€ 1.353,-$. De verschillen in verdiensten worden veroorzaakt door de inschaling volgens het functiewaarderingssysteem. Zo worden BBL'ers (samen met apotheekhulpen en bezorgers) in schaal 3 ingedeeld waarbij een minimum bruto maandsalaris van $€ 1$.397,- en een maximum van $€ 1.746$,- geldt. De hoogte van het salaris hangt vervolgens af van leeftijd en ervaring. Voor de 'gewone' apothekersassistenten geldt dat ze ingeschaald zijn in schaal 6 , terwijl de variant-assistenten in schaal 7 zitten.

Tabel 2.18

Gemiddeld bruto maandsalaris bij een 36-urige werkweek, 2004

Gemiddeld bruto salaris

(euro)

\begin{tabular}{ll}
\hline & \\
Apothekersassistent & 2.013 \\
Variant-apothekersassistent & 2.177 \\
BBL'er & 1.353 \\
Apotheekhulp & 1.529 \\
Administratief en secretarieel medewerker & 1.816 \\
Bezorger & 1.507 \\
Schoonmaker & 1.476 \\
\hline
\end{tabular}

Bron: ROA

Vergeleken met de situatie in 2001 (voor de invoering van het functiewaarderingssysteem) is het salaris flink gestegen. In 2001 verdienden apothekersassistenten gemiddeld $€ 1.802$,- bruto per maand (bij een 36-urige werkweek). De CAO lonen stegen in de periode 2001-2004 gemiddeld met ongeveer $7 \%{ }^{15}$ waardoor de loonstijging ten gevolge van het functiewaarderingssysteem uitkomt op $6 \%$ over de gehele periode.

\subsection{Loopbaan- en arbeidsmarktperspectieven van apothekersassistenten}

Welk beeld hebben apothekersassistenten van hun toekomst in de openbare apotheek? $75 \%$ van de apothekersassistenten en variant-apothekersassistenten denkt over 5 jaar nog altijd werkzaam te zijn in dezelfde openbare apotheek waar ze momenteel werken (zie tabel 2.19). Dit is beduidend meer dan in 2001, toen nog $69 \%$ van de assistenten aangaf over 5 jaar in dezelfde apotheek te werken. $7 \%$ van de 'gewone' apothekersassistenten verwacht over 5 jaar in een andere openbare apotheek werkzaam te zijn, terwijl slechts $4 \%$ van de apothekersassistenten met een variant-functie dezelfde verwachtingen heeft. Wel geven meer variant-assistenten aan over 5 jaar buiten de sector te werken (13\% tegenover 10\% van de 'gewone' assistenten). Ongeveer $5 \%$ van de apothekersassistenten zegt over 5 jaar gestopt te 
zijn met werken. Pensionering of tijdelijke terugtreden van de arbeidsmarkt om zorgtaken uit te voeren zijn mogelijke redenen voor apothekersassistenten om te stoppen met werken.

Tabel 2.19

Verwachte arbeidsmarktsituatie over 5 jaar van apothekersassistenten, 2004

\begin{tabular}{lcc}
\hline Werkzaam in & $\begin{array}{c}\text { Apothekersassistent } \\
\%\end{array}$ & $\begin{array}{c}\text { Variant-apothekersassistent } \\
\%\end{array}$ \\
\hline Dezelfde openbare apotheek & 75 & 75 \\
Andere openbare apotheek & 7 & 4 \\
Buiten de openbare apotheek & 2 & 3 \\
Buiten de sector & 10 & 13 \\
Gestopt met werken & 6 & 5 \\
\hline
\end{tabular}

Bron: ROA

De reden waarom apothekersassistenten over 5 jaar weg willen uit de huidige apotheek wordt weergegeven in tabel 2.20. Hieruit blijkt dat met name de apothekersassistenten met een variant-functie van mening zijn dat ze elders betere loopbaanperspectieven en een hoger salaris kunnen krijgen. Verder is $22 \%$ van mening dat het huidige werk niet bevredigend is. De 'gewone' apothekersassistenten ervaren daarnaast ook de hoge werkdruk $(23 \%)$ als één van de redenen om de huidige apotheek te verlaten.

Tabel 2.20

Redenen van apothekersassistenten om over 5 jaar niet meer in de huidige apotheek te werken*, 2004

\begin{tabular}{lcc}
\hline & Apothekersassistent & $\begin{array}{c}\text { Variant- } \\
\text { apothekersassistent } \\
\%\end{array}$ \\
& $\%$ & 44 \\
Betere loopbaanperspectieven elders & 26 & 34 \\
Hoger salaris elders & 22 & 22 \\
Soort werk is niet bevredigend & 22 & 3 \\
Te weinig werk & 2 & 12 \\
Te lange reistijd & 9 & 16 \\
Te hoge werkdruk & 23 & 4 \\
Onregelmatige werktijden & 2 & 21 \\
Werksfeer & 20 & 10 \\
Werkomstandigheden & 5 & 18 \\
Opleiding volgen & 16 & 22 \\
Zorg voor kinderen & 19 & 8 \\
Gezondheidsproblemen & 5 & 4 \\
Verhuizing & 9 & 4 \\
Onenigheid op de werkvloer & 6 & 0 \\
Ontslag door werkgever & 2 & 11 \\
Pensionering & 17 & 26 \\
Anders & 21 & \\
& & \\
\hline
\end{tabular}

* Omdat apothekersassistenten meerdere redenen kunnen noemen tellen de percentages niet op tot 100

Bron: ROA

Naast de toekomstverwachtingen van apothekersassistenten in de openbare apotheek, kunnen we ook nagaan of zij op het moment van de enquête (begin 2004) 
actief op zoek zijn naar een andere baan. Tabel 2.21 laat zien dat ruim $90 \%$ van alle apothekersassistenten werkzaam in de openbare apotheek niet op zoek is naar een andere baan. Toch is bijna één op de tien apothekersassistenten wel op zoek naar een andere baan. $2 \%$ van de assistenten wil wel apothekersassistent blijven, maar dan in een andere openbare apotheek dan de huidige. $6 \%$ van de apothekersassistenten wil echter een andere functie (zowel binnen als buiten de sector). Overigens is vergeleken met 2001 een lager percentage apothekersassistenten op zoek naar een andere baan: $11 \%$ in 2001 ten opzichte van $8 \%$ nu. Het lijkt er dus op dat met de invoering van het functiewaarderingssysteem een stap gezet is om meer apothekersassistenten voor de apotheekbranche te behouden.

Tabel 2.21

Zoekgedrag van apothekersassistenten, 2004

\begin{tabular}{|c|c|c|}
\hline & $\begin{array}{l}\text { Apothekers- } \\
\text { assistent } \\
\%\end{array}$ & $\begin{array}{c}\text { Variant- } \\
\text { apothekersassistent } \\
\%\end{array}$ \\
\hline Niet op zoek naar een andere baan & 91 & 92 \\
\hline $\begin{array}{l}\text { Op zoek naar... } \\
\text {...dezelfde functie in een andere openbare apotheek } \\
\text {...dezelfde functie buiten de openbare apotheek } \\
\text {...een andere functie binnen de sector } \\
\text {...een andere functie buiten de sector }\end{array}$ & $\begin{array}{l}2 \\
1 \\
3 \\
3\end{array}$ & $\begin{array}{l}1 \\
0 \\
4 \\
2\end{array}$ \\
\hline
\end{tabular}

Bron: ROA 


\section{Ontwikkelingen in het werk binnen de apotheek}

In dit hoofdstuk gaat de aandacht uit naar de veranderingen in de inhoud van het werk en de taakverdeling tussen de verschillende functies. Ook wordt in kaart gebracht welke taken van apothekersassistenten door apotheekhulpen worden overgenomen. Daarnaast wordt ingegaan op de vraag hoe de medewerkers in de verschillende functies hun werkdruk en arbeidsomstandigheden ervaren en hoe hoog hun ziekteverzuim is. Ten slotte wordt onderzocht hoe tevreden ze zijn met de verschillende aspecten van hun baan.

\subsection{Veranderingen in het werk}

Aan de apothekersassistenten is gevraagd op welke terreinen zich de afgelopen twee jaar veranderingen in hun werk hebben voorgedaan. Tabel 3.1 laat zien dat $83 \%$ van de assistenten vindt dat de mondigheid van cliënten is toegenomen. Ook geeft meer dan driekwart van de assistenten aan dat de intensiteit van de patiëntenvoorlichting en het aanbod van nieuwe producten is toegenomen. Meer in het algemeen is het opmerkelijk hoe groot de dynamiek in het werk van de apothekersassistenten de afgelopen twee jaar is geweest. Zo vindt een groot deel van de assistenten dat er sprake is geweest van een toename van de klantgerichtheid $(68 \%)$, de vereiste geneesmiddelenkennis (59\%), de werkdruk (59\%), de handverkoop (56\%), het gebruik van ICT (54\%) en de koppeling met het artsensysteem (53\%). Daarnaast wordt farmaceutische zorg in toenemende mate naar de thuissituatie verplaatst $(42 \%)$. Opmerkelijk is ook dat $37 \%$ van de assistenten aangeeft dat zij in toenemende mate taken van de apotheker overneemt. $\mathrm{Er}$ is in feite maar één activiteit die de afgelopen jaren is afgenomen: het zelf bereiden van medicijnen $(62 \%)$.

De variant-apothekersassistenten schetsen globaal gezien eenzelfde beeld van de veranderingen in hun werk. Wel ligt het percentage variant-apothekersassistenten dat aangeeft dat er sprake is van veranderingen over de gehele linie wat hoger. Mogelijk is dit toe te schrijven aan het feit dat apotheken met meer functiedifferentiatie op een aantal terreinen voorlopers zijn. Het verschil met de 'gewone' apothekersassistenten is het grootst bij het overnemen van taken van de apotheker. Maar liefst $57 \%$ van de variant-apothekersassistenten geeft aan meer taken te hebben overgenomen van de apotheker. Zoals verwacht mocht worden is dit vooral het geval bij de assistenten die werkzaam zijn in de coördinerende variant (64\%). Daarentegen ervaren relatief veel assistenten die werkzaam zijn in de variant kwaliteitszorg een toenemende verplaatsing van farmaceutische zorg naar de thuissituatie $(63 \%)$.

Het beeld dat de assistenten schetsen van de veranderingen in hun werk komt overigens aardig overeen met het beeld dat de apothekers hiervan hebben. ${ }^{16}$ Opmerkelijk is wel dat apothekers vaker vinden dat het zelfstandig werken van hun

16. Zie I. Sieben, A. de Grip en M. Hensen (2004), Apothekers en de openbare apotheek: Arbeidsmarktmonitor Apotheekbranche 2003-2004, ROA-R-2004/4, Maastricht, p. 17. 
assistenten is toegenomen (43\%), terwijl maar $32 \%$ van de assistenten dit ook vindt. Daarentegen geven de assistenten veel vaker aan dat het aanbod van nieuwe producten is toegenomen ( $77 \%$ tegenover $41 \%$ van de apothekers). Hetzelfde geldt voor de handverkoop. $56 \%$ van de assistenten geeft aan dat de handverkoop is toegenomen, tegenover $31 \%$ van de apothekers.

Tabel 3.1

Veranderingen in het werk van apothekersassistenten, 2004

\begin{tabular}{|c|c|c|c|c|}
\hline \multirow[b]{2}{*}{ Veranderingen in werk } & \multicolumn{2}{|c|}{ Apothekersassistent } & \multicolumn{2}{|c|}{$\begin{array}{c}\text { Variant-apothekers- } \\
\text { assistent }\end{array}$} \\
\hline & $\underset{\%}{\text { Toename }}$ & $\underset{\%}{\text { Afname }}$ & $\underset{\%}{\text { Toename }}$ & Afname \\
\hline Mondigheid van cliënten & 83 & 0 & 85 & 0 \\
\hline Intensiteit patiëntenvoorlichting & 77 & 3 & 82 & 3 \\
\hline Nieuw productaanbod & 77 & 1 & 78 & 1 \\
\hline Klantgerichtheid & 68 & 3 & 76 & 1 \\
\hline Vereiste geneesmiddelenkennis & 59 & 2 & 67 & 1 \\
\hline Werkdruk & 59 & 7 & 61 & 8 \\
\hline Handverkoop & 56 & 6 & 54 & 6 \\
\hline Gebruik van ICT & 54 & 1 & 58 & 1 \\
\hline Koppeling met artsensysteem & 53 & 1 & 48 & 1 \\
\hline Verplaatsen farmaceutische zorg naar thuis- & & & & \\
\hline situatie & 42 & 2 & 54 & 1 \\
\hline Assistenten nemen taken over van apotheker & 37 & 3 & 57 & 4 \\
\hline Zelfstandig werken & 32 & 4 & 40 & 4 \\
\hline Begeleiden van assistenten in opleiding & 27 & 12 & 37 & 9 \\
\hline Samenwerking in team & 25 & 8 & 26 & 9 \\
\hline Werknemers nemen taken van elkaar over & 24 & 3 & 30 & 3 \\
\hline Verzorgen van spreekuren & 18 & 7 & 25 & 6 \\
\hline Apotheker neemt taken over van assistenten & 14 & 21 & 14 & 22 \\
\hline Zelf bereiden & 7 & 62 & 6 & 67 \\
\hline
\end{tabular}

Bron: ROA

Hoewel de cijfers, vanwege de veranderde vraagstelling, niet helemaal vergelijkbaar zijn met die uit 2001, blijkt er ten aanzien van de toename van de mondigheid van cliënten, de intensiteit van de patiëntenvoorlichting en de toenemende klantgerichtheid duidelijk sprake te zijn van een langere-termijn trend. Ook in 2001 waren dit de meest genoemde veranderingen. Daarentegen zijn andere ontwikkelingen de laatste jaren in een stroomversnelling geraakt. Zo zijn er nu vier maal zoveel assistenten als in 2001 , die aangeven dat er sprake is van een toename van het aanbod van nieuwe producten. In vergelijking met 2001 wordt er nu ook meer dan twee keer zo vaak aangeven dat de handverkoop is toegenomen. Eveneens is er een verdubbeling van het percentage assistenten dat geeft dat het verplaatsen van farmaceutische zorg naar de thuissituatie sterk is toegenomen.

\subsection{Takenpakket en werkverdeling}

Welke werkzaamheden verrichten de medewerkers die in een bepaalde functie in de openbare apotheek werkzaam zijn? En op welke punten is er overlap in het takenpakket van de verschillende functies en op welke punten is er sprake van een duidelijke specialisatie? Tabel 3.2 laat zien dat de assistenten die werkzaam zijn in een 'gewone' functie bijna 60\% van hun werktijd bezig zijn met het aanschrijven, uitvullen en afleveren van recepten. Ook de apothekersassistenten in de variant FPZ 
besteden meer dan de helft van hun werktijd aan deze activiteiten. Bij de apothekersassistenten die werkzaam zijn in de variant kwaliteitszorg nemen deze activiteiten nog $46 \%$ van hun werktijd in beslag. De apothekersassistenten in de variant coördinerend houden zich nog minder met deze balieactiviteiten bezig; bij hen gaat slechts $39 \%$ van de werktijd aan deze activiteiten op.

Het takenpakket van de apothekersassistenten in de variant FPZ staat in het algemeen het dichtst bij het takenpakket van de 'gewone' assistenten. In beide functies besteden de assistenten even veel tijd aan het bewaken van medicatie (9\%), het bereiden van geneesmiddelen ( $8 \%$ ) en het bewaken van de voorraad $(5 \%)$. Daarentegen besteden de assistenten in de variant FPZ iets meer van hun werktijd aan de farmaceutische patiëntenzorg, het realiseren, bewaken en bevorderen van kwaliteitsbeleid, leidinggeven, begeleiden van assistenten in opleiding en administratieve werkzaamheden. De verschillen zijn telkens echter minimaal.

De takenpakketten van de beide andere variant-functies zijn iets meer geprononceerd, al gaat het ook bij deze functies om accentverschillen met de 'gewone' apothekersassistenten. De assistenten die werkzaam zijn in de variant coördinerend besteden met name meer tijd aan het leidinggeven (10\% van hun werktijd). De assistenten die werkzaam zijn in de variant kwaliteitszorg besteden met name meer tijd aan het realiseren, bewaken en bevorderen van kwaliteitsbeleid (12\% van hun werktijd). Deze verschillen tussen het takenpakket van de 'gewone' assistenten en de variant-apothekersassistenten illustreren dat er binnen de apotheekbranche daadwerkelijk invulling wordt gegeven aan de in het nieuwe functiewaarderingssysteem onderscheiden specialisaties. Hierbij gaat het echter vooralsnog om beperkte accentverschillen in het takenpakket. De tijd zal het leren of deze verschillen de komende jaren gering blijven, of zullen toenemen als gevolg van een verdergaande specialisatie op de werkvloer.

Tabel 3.2 laat ook zien welke werkzaamheden de apotheekhulpen verrichten. Apotheekhulpen worden vooral ingezet voor het uitvullen van recepten. Hieraan besteden zij $21 \%$ van hun werktijd. Het aanschrijven en afleveren van recepten behoort ook tot hun werkzaamheden, hoewel veel minder dan bij de apothekersassistenten. Apotheekhulpen besteden relatief veel tijd aan het bewaken van de voorraad (13\% van hun werktijd) en worden op beperkte schaal ook ingeschakeld bij het bereiden van medicijnen (4\% van de werktijd). Daarnaast bezorgen apotheekhulpen medicijnen ( $8 \%$ van de werktijd) en verrichten ze schoonmaak- en huishoudelijke taken ( $9 \%$ van de werktijd). Ten slotte geven de apotheekhulpen aan maar liefst $26 \%$ van hun werktijd te besteden aan allerlei 'overige taken'. Dit betekent dat de apotheekhulpen op diverse terreinen hand- en spandiensten verrichten ter ondersteuning van de overige apotheekmedewerkers. 


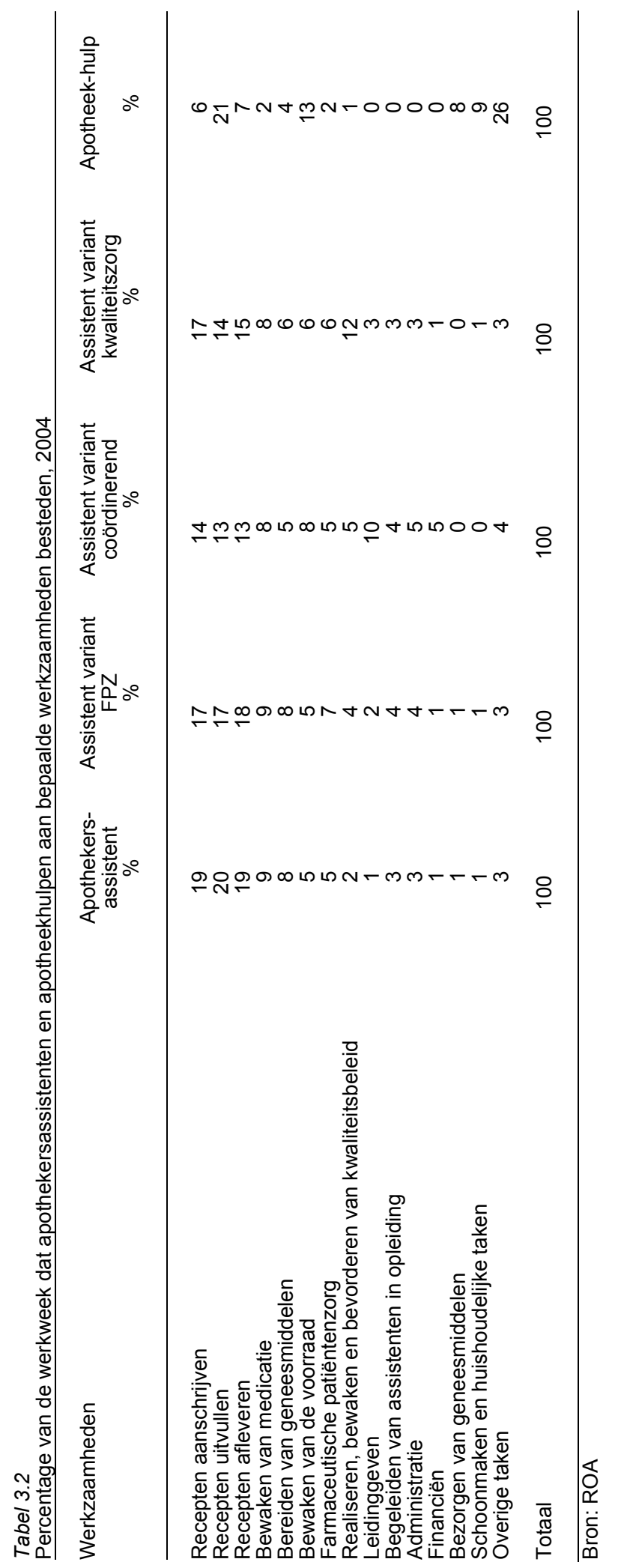


Tabel 3.3

Functies waarin medewerkers het meest bepaalde farmaceutische werkzaamheden verrichten, 2004

\begin{tabular}{rr}
\hline $\begin{array}{c}\text { Aandeel in } \\
\text { werkweek } \\
\%\end{array}$ & $\begin{array}{r}\text { Aandeel in } \\
\text { werkweek } \\
\%\end{array}$ \\
\end{tabular}

Recepten aanschrijven

Apothekersassistent

Assistent variant kwaliteitszorg

Assistent variant FPZ

BBL'er

Assistent variant coördinerend

\section{Recepten afleveren}

Apothekersassistent

Assistent variant FPZ

Assistent variant kwaliteitszorg

BBL'er

Assistent variant coördinerend

Bereiden van geneesmiddelen

BBL'er

Apothekersassistent

Assistent variant FPZ

Assistent variant kwaliteitszorg

Assistent variant coördinerend

Farmaceutische patiëntenzorg

Assistent variant FPZ

Assistent variant kwaliteitszorg

Assistent variant coördinerend

Apothekersassistent

BBL'er
Recepten uitvullen

19 BBL'er 25

17 Apotheekhulp 21

17 Apothekersassistent 20

15 Assistent variant FPZ 17

14 Assistent variant kwaliteitszorg 14

\section{Bewaken van medicatie}

19 Assistent variant FPZ

18 Apothekersassistent

Assistent variant kwaliteitszorg

Assistent variant coördinerend

13 BBL'er

9

9

8

Bewaken van de voorraad

18 Apotheekhulp

8 Assistent variant coördinerend

BBL'er

Assistent variant kwaliteitszorg

Assistent variant FPZ

Realiseren, bewaken en bevorderen van kwaliteitsbeleid

7 Assistent variant kwaliteitszorg

6 Assistent variant coördinerend

Assistent variant FPZ

BBL'er

Apothekersassistent

5
7
4



9
9
8
8
5

Bron: ROA

Tabel 3.3 laat zien in welke functies apotheekmedewerkers het meest bepaalde farmaceutische werkzaamheden uitvoeren. ${ }^{17}$ Uit de tabel blijkt dat de apothekersassistenten die werkzaam zijn in een gewone functie relatief gezien de meeste tijd besteden aan het aanschrijven en afleveren van recepten, terwijl de BBL'ers vooral worden ingezet voor het uitvullen van recepten en het bereiden van geneesmiddelen. Daarentegen besteden de assistenten in de variant FPZ en de 'gewone' assistenten relatief de meeste tijd aan het bewaken van medicatie, terwijl de assistenten in de variant FPZ in verhouding ook de meeste tijd aan de farmaceutische patiëntenzorg besteden. De verschillen zijn echter erg klein. De assistenten die werkzaam zijn in de variant kwaliteitszorg besteden duidelijk de meeste tijd aan het realiseren, bewaken

17. Dit betekent niet dat de desbetreffende taak voor het grootste deel door deze medewerkers wordt uitgevoerd. Er zijn immers grote verschillen in de omvang van de verschillende functiegroepen. Bovendien zullen degenen die werkzaam zijn in een hogere functie bepaalde werkzaamheden mogelijk efficiënter uitvoeren. 
en bevorderen van kwaliteitsbeleid. Apotheekhulpen besteden relatief veel werktijd aan het bewaken van de voorraad.

Tabel 3.4

Functies waarin medewerkers het meest diverse andere taken verrichten, 2004

$\begin{array}{rr}\begin{array}{r}\text { Aandeel in } \\ \text { werkweek }\end{array} & \begin{array}{r}\text { Aandeel in } \\ \text { werkweek } \\ \%\end{array} \\ & \%\end{array}$

Leidinggeven

Assistent variant coördinerend Assistent variant kwaliteitszorg Assistent variant FPZ

Administratief \& secretarieel medewerk. Apothekersassistent

Administratie

Administratief \& secretarieel medewerk. Apotheekhulp

Assistent variant coördinerend

Assistent variant FPZ

Assistent variant kwaliteitszorg

Bezorgen van geneesmiddelen

Bezorger
Apotheekhulp
BBL'er
Schoonmaker
Administratief \& secretarieel medewerk.

Begeleiden van assistenten in opleiding

10 Assistent variant coördinerend

Assistent variant FPZ

Assistent variant kwaliteitszorg

Apothekersassistent

Apotheekhulp

\section{Financiën}

46 Administratief \& secretarieel medewerk.

Assistent variant coördinerend

Assistent variant kwaliteitszorg

Apothekersassistent

Assistent variant FPZ

Schoonmaken en huishoudelijke taken

Schoonmaker

Apotheekhulp

Bezorger

BBL'er

Apothekersassistent
30

5

Overige taken

Apotheekhulp

Administratief \& secretarieel medewerk.

Bezorger

Assistent variant coördinerend

BBL'er

22
8
7
4
4

Bron: ROA

Tabel 3.4 geeft eenzelfde overzicht voor de verschillende andere taken die in de apotheek worden verricht. Hieruit blijkt dat de variant-apothekersassistenten relatief gezien de meeste werktijd besteden aan leidinggeven en aan het begeleiden van assistenten in opleiding. Verder laat de tabel duidelijk zien dat degenen die werkzaam zijn in de verschillende andere functiegroepen zich duidelijk richten op een bepaald soort werkzaamheden. Zo besteden bezorgers gemiddeld $84 \%$ van hun werktijd aan het bezorgen van medicijnen, terwijl schoonmakers $94 \%$ van hun werktijd besteden aan schoonmaak- en huishoudelijke taken. Ook de apotheekhulpen worden voor dit soort werkzaamheden ingezet. Gemiddeld besteden zij 8\% van hun tijd aan schoonmaak- en huishoudelijke taken.

De administratief en secretarieel medewerkers besteden ruim driekwart van hun werktijd aan administratie en financiën. Daarnaast worden apotheekhulpen in be- 
perkte mate voor administratieve werkzaamheden ingezet. Ook blijken de variantapothekersassistenten werkzaamheden te verrichten op het terrein van administratie en financiën. Dit geldt het sterkst voor de assistenten die werkzaam zijn in de variant coördinerend.

\section{Plezier in het werk}

In hoeverre voeren de apotheekmedewerkers de verschillende taken nu met plezier uit? Zoals figuur 3.1 laat zien, slaat de balans bij zowel de apothekersassistenten als de apotheekhulpen positief door. De apothekersassistenten voeren vooral de farmaceutische en cliëntgerichte taken met plezier uit. Daarentegen verrichten ze activiteiten die onder hun functieniveau liggen met minder plezier. Dit geldt met name voor schoonmaken en huishoudelijke taken.

Ook apotheekhulpen geven aan het meeste plezier te ontlenen aan de cliëntgerichte taken: het afleveren, uitvullen en aanschrijven van recepten. Er zijn echter weinig werkzaamheden die veel apotheekhulpen met weinig plezier doen. Alleen schoonmaakwerkzaamheden worden door een deel van de apotheekhulpen (21\%) met weinig plezier verricht. BBL'ers blijken eveneens het meeste plezier te hebben in de cliëntgerichte taken. Daarnaast vinden ze het bereiden van geneesmiddelen erg leuk. Administratief en secretarieel medewerkers ontlenen het meeste plezier aan het verrichten van financiële (83\%) en administratieve taken (84\%), terwijl maar liefst $92 \%$ van de bezorgers aangeeft met veel plezier geneesmiddelen te bezorgen. Daarentegen blijken schoonmakers veel minder plezier te beleven aan hun primaire taak. Slechts $24 \%$ van hen vervult het schoonmaakwerk en huishoudelijke taken met veel plezier.

Bij de apothekersassistenten blijken er duidelijke verschillen te zijn in het plezier dat oudere assistenten (50+ers) en assistenten die jonger zijn dan 30 jaar aan de verschillende werkzaamheden ontlenen. ${ }^{18}$ Oudere assistenten ontlenen aan verschillende werkzaamheden minder plezier dan jongere assistenten. Daarbij gaat het om het uitvullen van recepten, het bewaken van medicatie, het bewaken van de voorraad, het begeleiden van assistenten in opleiding, het bezorgen van assistenten in opleiding, het bezorgen van geneesmiddelen en schoonmaken en huishoudelijke werkzaamheden. Daarentegen hebben de oudere apothekersassistenten meer plezier in het afleveren van recepten en het uitvoeren van administratieve en financiële werkzaamheden. Jongere assistenten blijken overigens ook in vergelijking met de assistenten in de leeftijdsgroep 30-49 jaar, meer plezier te hebben in het begeleiden van assistenten in opleiding.

18. Bij de apotheekhulpen is het aantal respondenten te klein om verschillen tussen leeftijdsgroepen te kunnen constateren. 
Figuur 3.1

Werkzaamheden die apothekersassistenten en apotheekhulpen veel en weinig plezier geven in hun werk, 2004
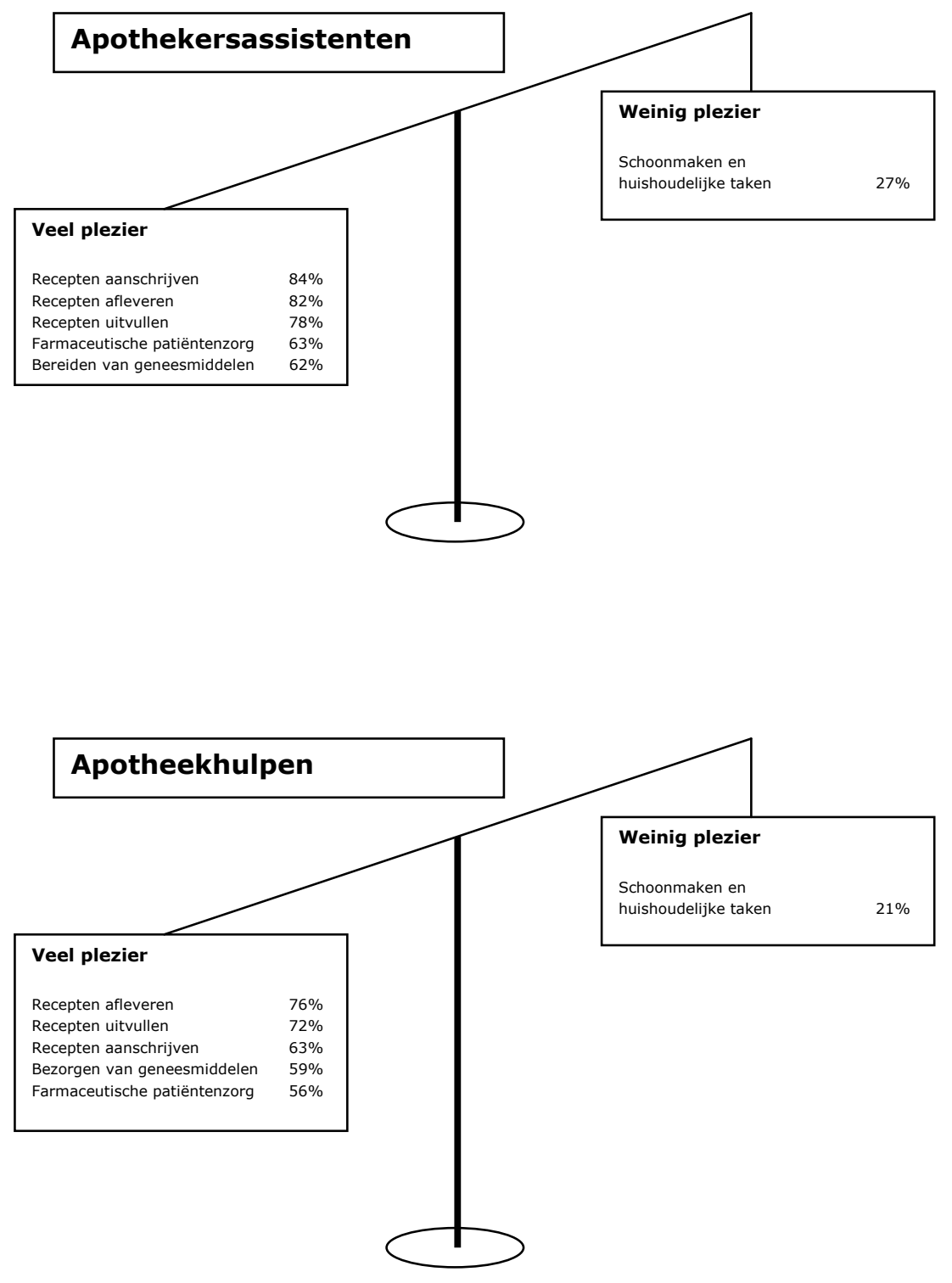

Bron: ROA 


\section{Verschuivingen in het takenpakket}

Wanneer we het takenpakket van de apothekersassistenten vergelijken met de taken die de assistenten in 2001 verrichtten, blijkt duidelijk dat er minder tijd besteed wordt aan het zelf bereiden van medicijnen (zie ook tabel 3.1). In 2001 besteedden de apothekersassistenten gemiddeld nog $13 \%$ van hun werktijd aan het bereiden van medicijnen; momenteel is dit nog slechts $8 \%$.

Ook het deel van de werktijd dat besteed wordt aan het bewaken van de medicatie is enigszins gedaald. In 2001 besteedden de assistenten hieraan gemiddeld $12 \%$ van hun werktijd, momenteel nog slechts $9 \%$. Daarentegen besteden de assistenten in 2004 ongeveer dezelfde tijd aan de farmaceutische patiëntenzorg als in 2001. In 2001 maakte FPZ gemiddeld 6\% van de werktijd van assistenten uit; momenteel is dit nog $5 \%$. Deze lichte daling is waarschijnlijk het geval van de nieuwe functiedifferentiatie. Zo besteden de apothekersassistenten in de variant FPZ gemiddeld 7\% van hun werktijd aan de farmaceutische patiëntenzorg.

Het is opmerkelijk dat de BBL'ers gemiddeld nog $18 \%$ van hun werktijd aan het bereiden van geneesmiddelen besteden. Enerzijds is dit begrijpelijk, omdat het bereiden van geneesmiddelen een leerzame activiteit is. Anderzijds kan dit het gevaar inhouden dat BBL'ers zich geen goed beeld vormen van de feitelijke werkpraktijk.

\section{Zelf uitgevoerde bereidingen}

Ondanks de afname in het aantal bereidingen in de openbare apotheek, voert nog ruim $80 \%$ van de assistenten zelf bereidingen uit (zie tabel 3.5 ). Hierbij is er vrijwel geen verschil tussen de assistenten die werkzaam zijn in een gewone functie en de variant-apothekersassistenten. De tabel laat ook zien welke bereidingen de assistenten uitvoeren. $78 \%$ van de assistenten verricht gestandaardiseerde bereidingen. Steriele bereidingen worden door veel minder assistenten verricht. Van de assisten-

Tabel 3.5

Bereiding van medicijnen door apothekersassistenten, 2004

\begin{tabular}{lcc}
\hline & $\begin{array}{c}\text { Variant- } \\
\text { apothekers- } \\
\text { assistent } \\
\%\end{array}$ \\
Bereiding van medicijnen & $\begin{array}{c}\text { assistent } \\
\%\end{array}$ & 82 \\
Bereid zelf medicijnen & 83 & 78 \\
Gestandaardiseerde bereidingen & 78 & 75 \\
Niet-gestandaardiseerde bereidingen & 71 & 55 \\
Steriele bereidingen & 49 & 34 \\
\hline
\end{tabular}

Bron: ROA

ten in een gewone functie verricht $49 \%$ deze bereidingen, tegenover $55 \%$ van de variant-apothekersassistenten. Met name de assistenten die werkzaam zijn in de 
variant kwaliteitszorg verrichten vaak steriele bereidingen (60\%). Bereidingen met risicovolle stoffen worden door bijna eenderde van de assistenten verricht. Van de 'gewone' assistenten verricht $30 \%$ dergelijke bereidingen; van degenen die werkzaam zijn in een variant-functie $34 \%$.

\subsection{Flexibele inzet}

Het nieuwe functiewaarderingssysteem heeft de mogelijkheden voor functiespecialisatie in de openbare apotheek aanzienlijk vergroot. Dit roept de vraag op in hoeverre apotheekmedewerkers werkzaamheden verrichten die strikt genomen niet bij hun functie horen. Wanneer apotheekmedewerkers taken verrichten die niet bij hun functie horen, geeft dit enerzijds een indicatie van de mate waarin de medewerkers vinden dat hun functie-inhoud aansluit bij hun functieomschrijving. Anderzijds geeft het ook een beeld van de flexibiliteit van de medewerkers.

Tabel 3.6 geeft aan dat $62 \%$ van de 'gewone' apothekersassistenten vindt dat ze geen werkzaamheden verrichten die eigenlijk niet tot hun functie behoren. Daarbij geeft $26 \%$ aan wel eens taken uit lagere functies te vervullen, terwijl $23 \%$ wel eens taken uit hogere functies verricht. Bij de variant-assistenten ligt het percentage medewerkers dat vindt dat ze wel eens taken uit andere functies verrichten duidelijk hoger. Dit is met name het geval bij de assistenten die werkzaam zijn in de variant coördinerend. Maar liefst $60 \%$ van deze variant-assistenten verricht taken die ze niet tot de eigen functie vindt behoren. $44 \%$ geeft daarbij aan taken uit hogere functies te verrichten, terwijl $41 \%$ aangeeft (ook) wel eens taken uit lagere functies uit te voeren. Kennelijk vervullen de variant-assistenten momenteel een schakelrol tussen het management van de apotheek en de assistenten in de 'gewone' assistentfuncties. Hoewel dit natuurlijk erg waardevol is voor de flexibiliteit van de organisatie, geeft het ook aan dat de feitelijke functie-inhoud van de nieuwe variant-functies nog niet goed is afgebakend van de inhoud van de hogere en lagere functies in de apotheek.

Tabel 3.6

Verrichten van taken uit andere functies, 2004

\begin{tabular}{lccc} 
& $\begin{array}{c}\text { Taken uit } \\
\text { hogere functies }\end{array}$ & $\begin{array}{c}\text { Taken uit } \\
\text { lagere } \\
\text { functies }\end{array}$ & $\begin{array}{c}\text { Geen } \\
\text { taken uit } \\
\text { andere } \\
\text { functies } \\
\%\end{array}$ \\
\hline Apothekersassistent & $\%$ & $\%$ & 62 \\
Apothekersassistent variant FPZ & 23 & 26 & 49 \\
Apothekersassistent variant coördinerend & 36 & 32 & 40 \\
Apothekersassistent variant kwaliteitszorg & 34 & 41 & 54 \\
BBL'er & 12 & 24 & 61 \\
Apotheekhulp & 28 & 15 & 49 \\
Administratief en secretarieel medewerker & 33 & 34 & 73 \\
Bezorger & 14 & 13 & 78 \\
Schoonmaker & 8 & 13 & \\
\hline Bron:ROA & & &
\end{tabular}

Bron: ROA

Ook de administratief en secretarieel medewerkers geven relatief vaak aan wel eens werkzaamheden te verrichten die niet tot hun eigen functie behoren. Hierbij gaat het vrijwel even vaak om taken uit hogere functies, als om taken uit lagere functies. 
Hieruit blijkt dat in het takenpakket van deze functies werkzaamheden met een sterk uiteenlopend niveau worden gecombineerd. Uit de tabel blijkt verder dat de werkzaamheden van de BBL'ers meestal goed aansluiten bij hun functie. Slechts een kwart van de BBL'ers verricht wel eens werkzaamheden die niet tot hun eigen functie behoren. Ten slotte valt op dat als apotheekhulpen werkzaamheden verrichten die niet tot hun eigen functie behoren, het hierbij vooral gaat om taken uit hogere functies.

Op welke terreinen nemen apotheekhulpen de assistenten nu werk uit handen? Om hierop een antwoord te kunnen geven, moet allereerst gekeken worden naar het aantal apotheken waarin apotheekhulpen werkzaam zijn. Uit het werkgeversonderzoek blijkt dat $43 \%$ van de apotheken algemeen ondersteunende medewerkers in dienst heeft. Gemiddeld gaat het hierbij om 0,9 fte.

Tabel 3.7

Taken van apothekersassistenten die door apotheekhulpen worden overgenomen, 2004

\begin{tabular}{lrr} 
Taken & $\begin{array}{c}\text { Apothekers- } \\
\text { assistent }\end{array}$ & $\begin{array}{c}\text { Variant } \\
\text { apothekers- } \\
\text { assistent } \\
\%\end{array}$ \\
\hline Geen taken & $\%$ & 17 \\
Recepten aanschrijven & 17 & 8 \\
Recepten uitvullen & 9 & 40 \\
Recepten afleveren & 36 & 10 \\
Bewaken van medicatie & 8 & 3 \\
Bereiden van geneesmiddelen & 3 & 10 \\
Bewaken van de voorraad & 9 & 23 \\
Farmaceutische patiëntenzorg & 26 & 3 \\
Realiseren, bewaken en bevorderen van kwaliteitsbeleid & 3 & 1 \\
Leidinggeven & 3 & 0 \\
Begeleiden van assistenten in opleiding & 2 & 2 \\
Administratie & 4 & 28 \\
Financiën & 30 & 9 \\
Bezorgen van geneesmiddelen & 15 & 46 \\
Schoonmaken en huishoudelijke taken & 49 & 56 \\
Overige taken & 57 & 21
\end{tabular}

Bron: ROA

Bij de apotheken die wel apotheekhulpen in dienst hebben blijken de apotheekhulpen de assistenten op verschillende terreinen te ondersteunen (zie tabel 3.7). Hierbij blijkt wel dat ook in de apotheken waar apotheekhulpen werkzaam zijn, de hulpen niet van alle apothekersassistenten werkzaamheden overnemen: $17 \%$ van de apothekersassistenten geeft aan dat apotheekhulpen nooit taken van hen overnemen. Van de andere assistenten nemen de apotheekhulpen vooral vaak werkzaamheden over waarvoor men geen middelbare beroepsopleiding hoeft te hebben gevolgd, zoals schoonmaken en huishoudelijke taken, bezorgen van geneesmiddelen en recepten uitvullen. Hieruit blijkt duidelijk dat de inzet van apotheekhulpen voorkomt dat de assistenten teveel werkzaamheden onder hun niveau moeten verrichten. Ook nemen de apotheekhulpen nogal eens administratieve werkzaamheden over en ondersteunen ze bij het bewaken van de voorraad. Overigens zijn er geen opmerkelijke verschillen in de soort taken die apotheekhulpen overnemen van 'gewone' apo- 
thekersassistenten en de taken die ze overnemen van de assistenten die werkzaam zijn in een variant-functie.

Aan de apothekersassistenten is ook gevraagd of ze vinden dat apotheekhulpen nog meer dan nu het geval is, bepaalde taken van hen zouden moeten overnemen. Maar liefst tweederde van de assistenten vindt dat apotheekhulpen hen nog meer werkzaamheden uit handen zouden kunnen nemen. Tabel 3.8 laat zien dat de assistenten die werkzaam zijn in een 'gewone' functie hierbij vooral denken aan schoonmaken en huishoudelijke taken $(21 \%)$, het bezorgen van geneesmiddelen $(18 \%)$, administratie $(14 \%)$ en het bewaken van de voorraad $(11 \%)$. Bij de apothekersassistenten die werkzaam zijn in een variant-functie liggen deze percentages nog wat hoger, met uitzondering van het overnemen van werkzaamheden met betrekking tot het bewaken van de voorraad. Uit deze cijfers blijkt dat de assistenten vinden dat apotheekhulpen hen op de terreinen waarop ze al ondersteuning bieden, nog meer werkzaamheden uit handen kunnen nemen dan momenteel reeds gebeurt. Dit zou als voordeel hebben dat apothekersassistenten minder activiteiten onder hun niveau zouden hoeven te verrichten. Apotheken zouden vanuit dit perspectief wellicht meer apotheekhulpen kunnen aantrekken dan ze momenteel in dienst hebben.

Tabel 3.8

Taken die volgens apothekersassistenten meer dan nu het geval is door apotheekhulpen zouden moeten worden overgenomen, 2004

\begin{tabular}{lrr}
\hline Taken & $\begin{array}{c}\text { Apothekers- } \\
\text { assistent }\end{array}$ & $\begin{array}{c}\text { Variant } \\
\text { Apothekers- } \\
\text { assistent } \\
\%\end{array}$ \\
\hline Geen taken & $\%$ & 32 \\
Recepten aanschrijven & 33 & 3 \\
Recepten uitvullen & 1 & 11 \\
Recepten afleveren & 9 & 2 \\
Bewaken van medicatie & 1 & 1 \\
Bereiden van geneesmiddelen & 0 & 5 \\
Bewaken van de voorraad & 4 & 8 \\
Farmaceutische patiëntenzorg & 11 & 1 \\
Realiseren, bewaken en bevorderen van kwaliteitsbeleid & 1 & 1 \\
Leidinggeven & 1 & 1 \\
Begeleiden van assistenten in opleiding & 0 & 1 \\
Administratie & 1 & 17 \\
Financiën & 14 & 9 \\
Bezorgen van geneesmiddelen & 9 & 22 \\
Schoonmaken en huishoudelijke taken & 18 & 24 \\
Overige taken & 21 & 11 \\
& 9 & \\
\hline Bron: ROA & & \\
\hline
\end{tabular}

\section{Bron: ROA}

Zoals tabel 3.9 laat zien, zouden de apotheekhulpen zelf ook wel meer administratieve taken van de apothekersassistenten willen overnemen (18\%). De andere relatief eenvoudige taken die de apothekersassistenten graag zouden willen doorschuiven naar apotheekhulpen, worden duidelijk niet door de apotheekhulpen zelf genoemd. Daarentegen willen de apotheekhulpen juist taken van de apothekersassistenten overnemen, die de assistenten zelf vrijwel niet noemen. Hierbij denken de apotheekhulpen vooral aan het uitvullen van recepten (20\%). 
Als we dit cijfer vergelijken met het huidige takenpakket van de apotheekhulpen (zie tabel 3.2), dan blijkt dat de apotheekhulpen momenteel reeds een belangrijk deel van hun tijd bezig zijn met het uitvullen van recepten (21\%). Dit geeft aan dat ze deze werkzaamheden goed aankunnen en ook zien als een verrijking van hun takenpakket. Daar staat tegenover dat de meeste apothekersassistenten er niet zoveel voor voelen dat apotheekhulpen dit werk nog meer van hen overnemen. Andere taken die de apotheekhulpen graag van de apothekersassistenten zouden willen overnemen zijn het bereiden van geneesmiddelen (14\%), het aanschrijven van recepten $(13 \%)$, het afleveren van recepten $(11 \%)$ en de farmaceutische patiëntenzorg $(10 \%)$. Deze taken sluiten veel minder goed aan bij het huidige takenpakket van de apotheekhulpen. Dit wijst er op dat dit soort taken toch minder gemakkelijk door de apotheekhulpen kunnen worden overgenomen dan ze zelf graag zouden willen. Het is vanzelfsprekend ook in strijd met de gewenste functiedifferentiatie. Het wijst er echter ook op dat een deel van de apotheekhulpen een doorgroeiperspectief ambieert, dat men door het volgen van een aanvullende opleiding zou kunnen realiseren.

BBL'ers zouden vooral graag meer taken willen verrichten op het terrein van de farmaceutische patiëntenzorg (37\%) en het aanschrijven van recepten (37\%). Daarnaast geeft $31 \%$ van de BBL'ers aan graag meer recepten aan cliënten te willen afleveren en geneesmiddelen te willen bereiden (30\%). Op al deze taakgebieden blijft de inzet van BBL'ers echter niet achter bij die van de 'gewone' apothekersassistenten. De BBL'ers besteden zelfs al meer dan twee keer zo veel tijd aan het bereiden van geneesmiddelen dan de apothekersassistenten (zie tabel 3.3). Men kan zich dan ook afvragen of men aan deze wensen van de BBL'ers tegemoet zou moeten komen. Enerzijds zou dit de leercomponent van hun beroepspraktijk waarschijnlijk vergroten. Anderzijds zou het echter het beeld dat de BBL'ers van de beroepspraktijk krijgen kunnen vertekenen, omdat men later als apothekersassistent dit soort werkzaamheden veel minder vaak zal verrichten. Het is belangrijk om hiervoor oog te hebben.

De administratief en secretariële medewerkers, bezorgers en schoonmakers zouden hun inzet vooral willen vergroten op de terreinen waarin ze zich reeds specialiseren. Dit geeft aan dat de medewerkers in deze functies graag de taken willen overnemen die apothekersassistenten vaak, nog meer dan nu het geval is, zouden willen afstoten: schoonmaken en huishoudelijke taken, het bezorgen van geneesmiddelen en administratieve taken. Apotheken zouden vanuit dit perspectief nog meer administratief en secretarieel personeel, bezorgers en schoonmakers kunnen aantrekken dan ze momenteel in dienst hebben, of ervoor kunnen kiezen dergelijke taken nog meer uit te besteden. ${ }^{19}$

Aan de apothekersassistenten is ook gevraagd in hoeverre de apotheker zelf taken uitvoert die normaal gesproken tot het takenpakket van de apothekersassistent worden gerekend. Met name de assistenten die werkzaam zijn in een gewone functie

19. Zie ook figuur 4.7 in I. Sieben, A. de Grip en M. Hensen (2004), Apothekers en de openbare apotheek: Arbeidsmarktmonitor Apotheekbranche 2003-2004, ROA-R-2004/4, Maastricht. 
hebben hier nogal eens geen goed beeld van: $36 \%$ geeft aan 'het niet te weten'; bij de assistenten die werkzaam zijn in een variant-functie is dat bij $24 \%$ het geval. Van de assistenten die wel een beeld hebben van de mate waarin de apotheker taken van hen overneemt, geeft bijna de helft aan dat de apotheker hieraan niet meer dan een halve dag per week taken besteedt (zie tabel 3.10). Daarentegen zegt $13 \%$ van de assistenten die deze vraag konden beantwoorden, dat de apotheker meer dan twee dagen per week taken van hen overneemt.

Tabel 3.9

Taken die apotheekmedewerkers graag meer dan nu het geval is, zouden willen verrichten, 2004

\begin{tabular}{|c|c|c|c|c|c|}
\hline Taken & $\begin{array}{c}\text { Apotheek- } \\
\text { hulp } \\
\%\end{array}$ & $\begin{array}{c}\text { BBL'er } \\
\% \\
\end{array}$ & $\begin{array}{c}\text { Admini- } \\
\text { stratie } \\
\%\end{array}$ & $\begin{array}{c}\text { Bezorgers } \\
\% \\
\end{array}$ & $\begin{array}{c}\text { Schoon- } \\
\text { makers } \\
\%\end{array}$ \\
\hline Geen taken & 37 & 22 & 50 & 52 & 42 \\
\hline Recepten aanschrijven & 13 & 37 & 4 & 2 & 0 \\
\hline Recepten uitvullen & 20 & 12 & 4 & 5 & 3 \\
\hline Recepten afleveren & 11 & 31 & 2 & 3 & 0 \\
\hline Bewaken van medicatie & 5 & 22 & 2 & 2 & 0 \\
\hline Bereiden van geneesmiddelen & 14 & 30 & 5 & 2 & 0 \\
\hline Bewaken van de voorraad & 8 & 11 & 3 & 3 & 2 \\
\hline Famaceutische patiëntenzorg & 10 & 37 & 7 & 2 & 0 \\
\hline $\begin{array}{l}\text { Realiseren, bewaken en } \\
\text { bevorderen van kwaliteitsbeleid }\end{array}$ & 6 & 14 & 6 & 1 & 1 \\
\hline Leidinggeven & 4 & 10 & 4 & 3 & 0 \\
\hline $\begin{array}{l}\text { Begeleiden van assistenten in } \\
\text { opleiding }\end{array}$ & 3 & 12 & 2 & 1 & 0 \\
\hline Administratie & 18 & 10 & 12 & 9 & 6 \\
\hline Financiën & 4 & 8 & 12 & 2 & 0 \\
\hline Bezorgen van geneesmiddelen & 4 & 1 & 1 & 22 & 10 \\
\hline $\begin{array}{l}\text { Schoonmaken en huishoudelijke } \\
\text { taken }\end{array}$ & 1 & 1 & 0 & 2 & 19 \\
\hline Overige taken & 50 & 3 & 4 & 6 & 13 \\
\hline
\end{tabular}

\section{Bron: ROA}

Tabel 3.10

Tijd dat apotheker taken van een apothekersassistent verricht, 2004

\begin{tabular}{lrr}
\hline Tijd & $\begin{array}{r}\text { Inschatting } \\
\text { apothekers- } \\
\text { assistenten } \\
\%\end{array}$ & $\begin{array}{r}\text { Inschatting } \\
\text { apothekers } \\
\text { zelf } \\
\%\end{array}$ \\
\hline Helemaal niet & 17 & 6 \\
Halve dag of minder per week & 29 & 21 \\
Halve tot hele dag per week & 19 & 30 \\
Eén tot twee dagen per week & 22 & 34 \\
Meer dan twee dagen per week & 13 & 10 \\
\hline
\end{tabular}

Bron: ROA

Het is interessant om de cijfers van tabel 3.10 te vergelijken met het beeld dat de apothekers zelf hebben van de mate waarin ze taken verrichten die normaal door de assistenten worden uitgevoerd. De tabel laat zien dat er op dit punt sprake is van een opmerkelijk perceptieverschil. De apothekersassistenten schatten de inzet van de apothekers op dit punt duidelijk lager in dan de apothekers zelf. Zo geeft slechts $27 \%$ van de apothekers aan dat ze niet meer dan een halve dag taken van hun assistenten overnemen, tegenover $46 \%$ van de assistenten. Dit wijst er op dat de inzet 34 
van apothekers zich nogal eens aan het beeld van de assistenten onttrekt; hetgeen eveneens naar voren kwam uit het grote aantal assistenten dat deze vraag niet kon beantwoorden.

\subsection{Werkdruk en ziekteverzuim}

Nu we het takenpakket van de verschillende groepen apotheekmedewerkers in beeld gebracht hebben, is het goed om eens te kijken hoe ze hun werkomstandigheden ervaren. In de eerste plaats is gekeken naar de werkdruk. Tabel 3.11 laat zien dat de werkdruk gemiddeld het hoogst is onder de apothekersassistenten. Daarbij is er geen verschil tussen de assistenten in een 'gewone' functie en de assistenten in een variant-functie. Ook is er weinig verschil met de BBL'ers. De werkdruk ligt echter duidelijk lager bij de schoonmakers, maar ook bij de bezorgers en het administratief en secretariële personeel is de werkdruk minder hoog.

Wanneer we de hoogste drie scores op de negenpuntsschaal beschouwen als het hebben van een hoge werkdruk, dan blijkt dat er bij $46 \%$ van de assistenten die werkzaam zijn in een variant-functie sprake is van een hoge werkdruk. Bij de assistenten ligt dit percentage iets lager: $42 \%$. Daarentegen ervaart slechts $31 \%$ van de apotheekhulpen een hoge werkdruk. Hieruit kan men afleiden dat het takenpakket van de medewerkers in de verschillende functies binnen de openbare apotheek, gezien de werkdruk, nog niet optimaal verdeeld is. Ook vanuit dit perspectief zou het wenselijk zijn als apotheekhulpen en andere medewerkers meer werkzaamheden van de apothekersassistenten zouden overnemen dan momenteel het geval is. Uit de cijfers van tabel 3.8 en 3.9 bleek al dat dit mogelijk zou moeten zijn.

Tabel 3.11

Werkdruk van apotheekmedewerkers (score 1 'geen werkdruk' tot en met 9 'extreem hoge werkdruk'), 2004

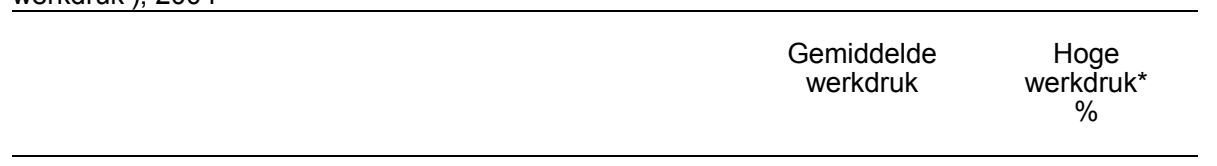

$\begin{array}{lrr} & & \\ \text { Apothekersassistent } & 5,7 & 42 \\ \text { Variant-apothekersassistent } & 5,7 & 46 \\ \text { BBL'er } & 5,6 & 38 \\ \text { Apotheekhulp } & 5,1 & 31 \\ \text { Administratief en secretarieel medewerker } & 4,9 & 29 \\ \text { Bezorger } & 4,5 & 21 \\ \text { Schoonmaker } & 2,7 & 8\end{array}$

* score 7-9

Bron: ROA

Uit het werkgeversonderzoek bleek dat de apothekers hun eigen werkdruk, met een gemiddelde score van 6,2 , nog hoger inschatten dan de werkdruk van hun assistenten. $^{20}$

20. Zie tabel 3.8 in I. Sieben, A. de Grip en M. Hensen (2004), Apothekers en de openbare apotheek: Arbeidsmarktmonitor Apotheekbranche 2003-2004, ROA-R-2004/4, Maastricht, p. 17. 
Overigens blijkt dat apothekers een goed beeld hebben van de werkdruk van hun assistenten: De gemiddelde score van de apothekers voor de werkdruk van hun assistenten stemt overeen met de gemiddelde score van de assistenten zelf. Ook blijkt dat apothekers duidelijk zien dat de werkdruk van hun assistenten gemiddeld hoger ligt dan de werkdruk voor de overige functies in de apotheek $(4,7)$.

Tabel 3.12 geeft een gedetailleerd overzicht van de mate waarin apotheekmedewerkers geconfronteerd worden met belastende arbeidsomstandigheden. Uit de tabel blijkt dat de helft van de apothekersassistenten altijd of vaak onder een hoge tijdsdruk werkt. Daarbij is er geen verschil tussen degenen die werkzaam zijn in een 'gewone' functie en de assistenten in de variant-functies. Van de BBL'ers werkt $41 \%$ altijd of vaak onder een hoge tijdsdruk, terwijl bij de apotheekhulpen slechts $29 \%$ altijd of vaak onder een hoge tijdsdruk werkzaam is. Bij de overige medewerkers ligt dit percentage nog (veel) lager. Overigens lijkt de tijdsdruk waaronder apothekersassistenten werken de laatste jaren iets te zijn afgenomen. Zo gaf in 2001 nog 54\% van de assistenten aan regelmatig onder hoge tijdsdruk te werken.

Over het algemeen is het werk van de meeste apotheekmedewerkers lichamelijk niet zo zwaar. Het merendeel geeft aan dat men slechts soms lichamelijk zwaar werk verricht. Daarentegen vindt 32\% van de 'gewone' apothekersassistenten dat ze altijd of vaak met geestelijk zwaar werk te maken hebben. Bij de variant-apothekersassistenten ligt dit percentage met $37 \%$ nog wat hoger; bij de BBL'ers met $30 \%$ juist iets lager. Voor de andere apotheekmedewerkers is het werk veel minder vaak geestelijk zwaar. Van de apotheekhulpen en de administratief of secretarieel medewerkers vindt $17 \%$ dat hun werk altijd of vaak geestelijk zwaar is. Van de bezorgers slechts $6 \%$.

Ongeveer een kwart van de apothekersassistenten vindt dat er altijd of vaak sprake is van fysiek belastende arbeidsomstandigheden in de vorm van lawaai, tocht, hoge of lage temperaturen, stof, etc.. De andere apotheekmedewerkers hebben duidelijk minder vaak te maken met dergelijke fysiek belastende arbeidsomstandigheden, met uitzondering van het administratief en secretarieel personeel. Het percentage assistenten dat aangeeft vaak of regelmatig onder fysiek belastende arbeidsomstandigheden te werken blijkt overigens te zijn toegenomen. In 2001 gaf immers 20\% van de assistenten aan regelmatig onder slechte arbeidsomstandigheden te moeten werken.

Het overgrote deel van de apothekersassistenten komt slechts soms in aanraking met gevaarlijke stoffen. Dit is bij $71 \%$ van de 'gewone' assistenten en $72 \%$ van de variant-apothekersassistenten het geval. Bij de BBL'ers komt $78 \%$ soms in aanraking met gevaarlijke stoffen. Het merendeel van de apotheekhulpen en de overige apotheekmedewerkers zegt nooit contact te hebben met gevaarlijke stoffen. 


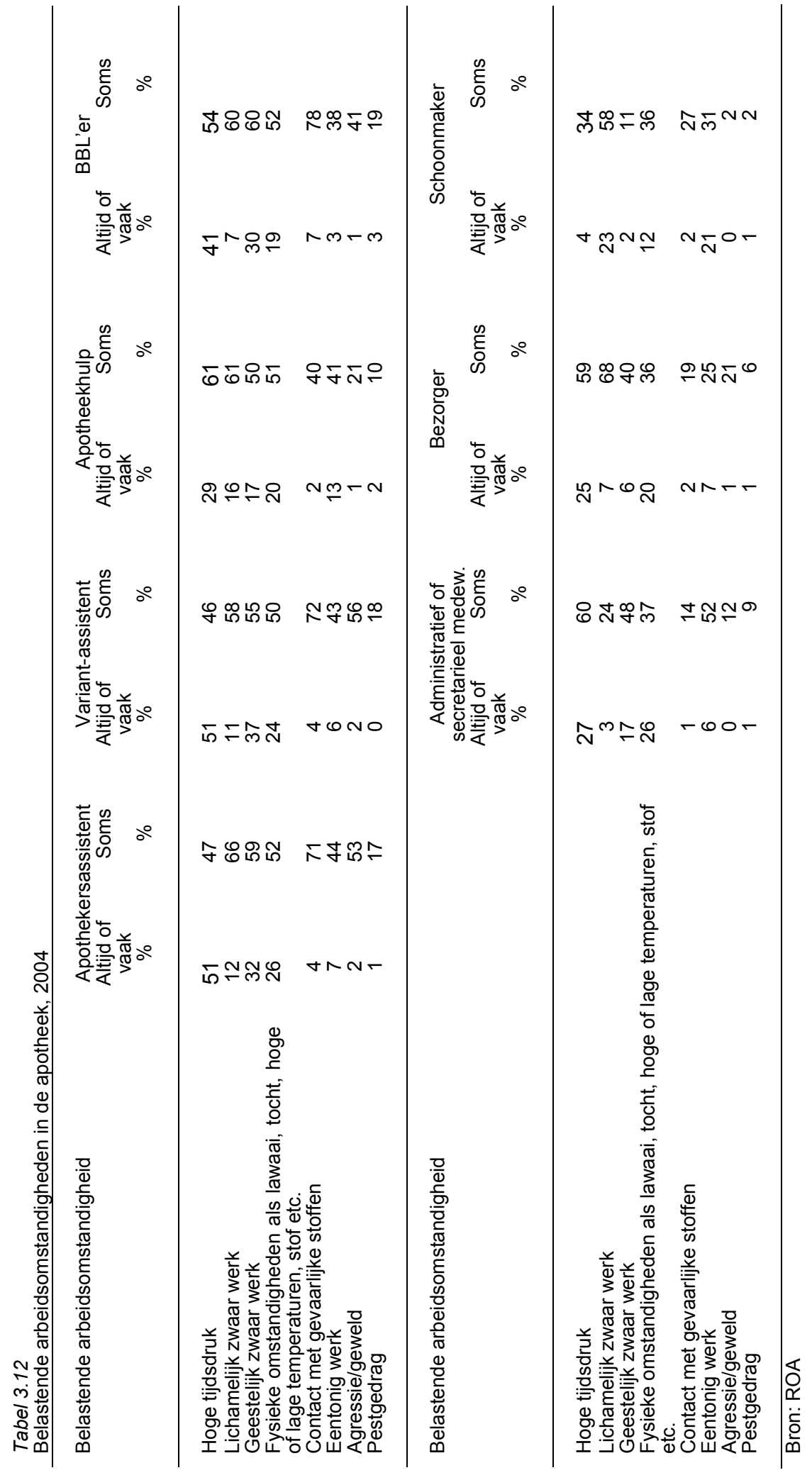


Een kleine groep assistenten (7\%) geeft aan dat ze altijd of vaak eentonig werk verrichten. Het is opmerkelijk dat dit ook bij de variant-assistenten het geval is $(6 \%)$. Daarnaast geeft een substantiële groep assistenten (44\% van degenen in een 'gewone' functie en $43 \%$ van de assistenten in een variant-functie) aan dat hun werk soms eentonig is. Dit is een toename ten opzichte van 2001 , toen $39 \%$ van de assistenten aangaf soms eentonig werk te verrichten. De BBL'ers verrichten minder eentonig werk. Daarentegen vindt $13 \%$ van de apotheekhulpen hun werk altijd of vaak eentonig, terwijl $41 \%$ het soms eentonig vindt. Een groot deel van het administratief personeel vindt het werk soms eentonig (52\%).

De apothekersassistenten worden in hun werk ook het meest geconfronteerd met agressie of geweld: $2 \%$ van de assistenten wordt hier zelfs vaak mee geconfronteerd. Dit betekent echter niet dat assistenten slechts in enkele apotheken met agressief gedrag worden geconfronteerd. Meer dan de helft van de assistenten geeft aan soms met agressie of geweld op het werk te maken te hebben. Bij de BBL' ers ligt dit percentage wat lager (41\%), terwijl van de apotheekhulpen $21 \%$ soms op het werk met agressie of geweld te maken heeft.

Ten slotte geeft $18 \%$ van de apothekersassistenten aan op het werk pestgedrag tegen te komen. Bij de meesten is dat gelukkig slechts soms het geval. Bij de BBL'ers heeft maar liefst $22 \%$ wel eens met pestgedrag te maken.

\section{Ziekteverzuim}

Tabel 3.13 geeft een overzicht van het ziekteverzuim onder de apotheekmedewerkers. Van de 'gewone' assistenten heeft in een jaar tijd 58\% zich minstens één keer ziek gemeld. Gemiddeld was een assistent hierbij ruim 10 dagen ziek. Van de assistenten die werkzaam zijn in een variant-functie is $52 \%$ één of meerdere keren ziek. Daarbij was men echter wel wat langer ziek (bijna 13 dagen). Overigens ligt het gemiddelde aantal dagen dat een assistent ziek was momenteel hoger dan in 2001. Toen bedroeg het aantal dagen dat iemand ziek was gemiddeld 9,5 dag. Uit de enquête onder de apothekers blijkt dat het ziekteverzuim onder apothekersassistenten $3,5 \%$ is, met een langdurig ziekteverzuim (langer dan 6 weken) van $1,9 \%$.

Het ziekteverzuim van de apotheekhulpen ligt wat hoger. Van deze ondersteunende medewerkers was $63 \%$ in een jaar tijd minimaal één maal ziek. Het aantal dagen dat apotheekhulpen ziek waren, was daarbij wat lager dan bij de assistenten: 9,3 dagen. Bij de BBL'ers lag het aantal ziekmeldingen nog hoger: $74 \%$ melde zich één of meerdere keren ziek. Bovendien waren BBL'ers in totaal wat langer ziek (gemiddeld bijna 15 dagen). Het ziekteverzuim lag verreweg het laagst bij de bezorgers. Hiervan meldde slechts $42 \%$ zich een of meerdere keren ziek. Wel lag de totale ziekteduur daarbij (bijna 16 dagen) wat hoger. 
Tabel 3.13

Ziekteverzuim in de afgelopen 12 maanden, 2004

Minimaal 1 keer ziek Aantal dagen ziek

$\%$

\begin{tabular}{lrr}
\hline & & \\
Apothekersassistent & 58 & 10,1 \\
Variant-apothekersassistent & 52 & 12,6 \\
BBL & 74 & 14,6 \\
Apotheekhulp & 63 & 9,3 \\
Administratief en secretarieel medewerker & 58 & 16,5 \\
Bezorger & 42 & 15,8 \\
Schoonmaker & 57 & 13,7 \\
\hline
\end{tabular}

Bron: ROA

Aan de medewerkers is ook gevraagd of de oorzaak van hun laatste ziekteverzuim te maken had met hun werk. Zoals tabel 3.14 laat zien, blijkt dat het overgrote deel van het ziekteverzuim in de openbare apotheek niet werkgerelateerd is. Dit geldt voor alle functies in de apotheek. Bij de bezorgers, apotheekhulpen en schoonmakers is het werkgerelateerde ziekteverzuim met 10 tot $12 \%$ het hoogst. Bij het administratief en secretarieel personeel is daarentegen slechts $5 \%$ van het ziekteverzuim werkgerelateerd.

Met welke aspecten van het werk heeft het ziekteverzuim van apotheekmedewerkers te maken? Bij de apothekersassistenten die werkzaam zijn in een gewone functie wordt $4 \%$ van het ziekteverzuim mede veroorzaakt door de hoge werkdruk, bij de variant-apothekersassistenten is dat bij slechts $2 \%$ van het ziekteverzuim het geval. 2 à $3 \%$ van het ziekteverzuim van asisitenten is gerelateerd aan de lichamelijke belasting die het werk met zich meebrengt. $\mathrm{Bij}$ de apotheekhulpen wordt eveneens $3 \%$ van het ziekteverzuim mede veroorzaakt door de fysieke belasting tijdens het werk. Bij de schoonmakers is dit zelfs bij $6 \%$ van het ziekteverzuim het geval.

Tabel 3.14

Oorzaken van ziekteverzuim, 2004

\begin{tabular}{lcccc}
\hline & $\begin{array}{c}\text { Ziekte had } \\
\text { niet met } \\
\text { werk te } \\
\text { maken } \\
\%\end{array}$ & $\begin{array}{c}\text { Hoge } \\
\text { werkdruk* }\end{array}$ & $\begin{array}{c}\text { Zware } \\
\text { lichamelijke } \\
\text { belasting* }\end{array}$ & $\begin{array}{c}\text { Ander } \\
\text { aspect } \\
\text { van het } \\
\text { werk* }^{*} \\
\%\end{array}$ \\
\hline Apothekersassistent & 91 & $\%$ & & 5 \\
Variant-apothekersassistent & 93 & 2 & 2 & 3 \\
BBL'er & 92 & 4 & 0 & 7 \\
Apotheekhulp & 90 & 3 & 3 & 6 \\
Administratief en secretarieel medewerk. & 95 & 4 & 1 & 5 \\
Bezorger & 88 & 2 & 1 & 12 \\
Schoonmaker & 90 & 0 & 6 & 6
\end{tabular}

* Bij de werkgerelateerde oorzaken van ziekteverzuim konden meerdere oorzaken worden aangegeven. Bron: ROA

Bij de meeste functies wordt een groot deel van het werkgerelateerde ziekteverzuim door andere aspecten van het werk veroorzaakt. Bij de bezorgers is zelfs $12 \%$ van 
het totale ziekteverzuim mede hieraan toe te schrijven. Op grond van de beschikbare gegevens kan niet worden aangegeven om welke aspecten van het werk het precies gaat. Wel zal in hoofdstuk 4 nader worden ingegaan op de relatie tussen het competentieniveau van medewerkers, hun werkdruk en het ziekteverzuim.

\subsection{Tevredenheid met het werk}

Een belangrijke maatstaf voor de 'overall' waardering die medewerkers voor hun baan hebben is hun tevredenheid met het werk. Aan de apotheekmedewerkers is allereerst gevraagd of ze "alles bijeengenomen" tevreden zijn met hun huidige baan. Tabel 3.15 laat zien dat het overgrote deel van de medewerkers tevreden is met hun werk. $28 \%$ van de apothekersassistenten is zelfs zeer tevreden met hun baan; bij de variant-apothekersassistenten ligt dit percentage nog iets hoger (31\%). Opmerkelijk is ook de grote tevredenheid van de BBL'ers met hun werk: $44 \%$ is zelfs zeer tevreden. Ook bij de bezorgers is een relatief grote groep zeer tevreden met hun baan.

Slechts een beperkte groep apotheekmedewerkers is niet tevreden met hun baan. Daarbij is het wel opmerkelijk dat de ontevredenheid het grootst is onder de 'gewone' assistenten. Wanneer we de cijfers van tabel 3.15 echter vergelijken met de uitkomsten van de eerste enquête die in 2001 in het kader van de Arbeidsmarktmonitor Apotheekbranche werd gehouden, dan valt op dat de tevredenheid onder de apothekersassistenten is toegenomen. In 2001 was nog slechts $26 \%$ van de assistenten zeer tevreden met hun werk $^{21}$, terwijl $2 \%$ van de apothekersassistenten helemaal niet tevreden was met hun werk, en $11 \%$ niet zo tevreden was.

Tabel 3.15

Tevredenheid met de huidige baan, 2004

\begin{tabular}{lcccc}
\hline & $\begin{array}{c}\text { Zeer } \\
\text { tevreden } \\
\%\end{array}$ & $\begin{array}{c}\text { Wel } \\
\text { tevreden } \\
\%\end{array}$ & $\begin{array}{c}\text { Niet zo } \\
\text { tevreden } \\
\%\end{array}$ & $\begin{array}{c}\text { Helemaal } \\
\text { niet } \\
\text { tevreden } \\
\%\end{array}$ \\
\hline $\begin{array}{l}\text { Apothekersassistent } \\
\text { Variant-apothekersassistent }\end{array}$ & 28 & 61 & 10 & 1 \\
BBL'er & 31 & 61 & 6 & 2 \\
Apotheekhulp & 44 & 51 & 5 & 0 \\
Administratief en secretarieel medewerk & 28 & 65 & 6 & 2 \\
Bezorger & 35 & 56 & 8 & 2 \\
Schoonmaker & 42 & 51 & 6 & 1 \\
& 33 & 61 & 5 & \\
\hline
\end{tabular}

Bron: ROA

Om een beeld te krijgen van de eventuele bronnen van onvrede, wordt in tabel 3.16 een overzicht gegeven van de verschillende aspecten van de baan waarmee apotheekmedewerkers niet tevreden zijn. Uit de tabel komt duidelijk naar voren dat er toch duidelijke punten van onvrede zijn, hoewel de meeste medewerkers over het geheel genomen tevreden zijn met hun baan. Van de apothekersassistenten die werkzaam zijn in een 'gewone' functie is meer dan de helft (52\%) niet tevreden met de loopbaanperspectieven. Dit is weliswaar wat minder dan in 2001 (57\%), maar het

21. Ook degenen die momenteel als variant-assistent werkzaam waren, vielen toen nog onder deze functiegroep. 
duidt er niet op dat de assistenten door de introductie van het nieuwe functiewaarderingssysteem over de gehele linie tevredener zijn geworden over hun loopbaanperspectieven. Hetzelfde geldt overigens ook voor de apothekersassistenten die werkzaam zijn in een variant-functie. Hiervan is $47 \%$ niet tevreden met hun loopbaanperspectieven. Ook is een aanzienlijke deel van de 'gewone' assistenten niet tevreden over het salaris (38\%), het leidinggeven door de apotheker (37\%) en de werkdruk $(36 \%)$. Bij de variant-apothekersassistenten is een kleiner deel niet tevreden over het salaris (30\%). Daarentegen is de ontevredenheid over de werkdruk bij hen wat groter $(40 \%)$. Hoewel de groep relatief niet groot is, is het toch goed om aandacht te hebben voor het feit dat ongeveer één op de zeven apothekersassistenten ontevreden is over de werksfeer (15\%) en de veiligheid op het werk (14\%). Ten slotte valt op dat er maar weinig assistenten zijn die ontevreden zijn over de zelfstandigheid waarmee zij kunnen werken (4\%) en de werktijden (7\%).

Ook de BBL'ers hebben de meeste onvrede met hun salaris; $33 \%$ is op dit punt niet tevreden. Daarentegen zijn de BBL'ers veel minder vaak dan de 'gewone' apothekersassistenten ontevreden met hun werkdruk (24\%), loopbaanperspectieven (22\%) en het leidinggeven door de apotheker (21\%).

Van de apotheekhulpen is bijna eenderde niet tevreden met het salaris. Daarnaast is een relatief grote groep apotheekhulpen niet tevreden over de loopbaanperspectieven (30\%) en de scholingsfaciliteiten die hen worden aangeboden (28\%). Dit geeft duidelijk aan dat een aanzienlijke groep apotheekhulpen zou willen doorgroeien binnen de apotheek.

Ook van de administratief en secretarieel medewerkers is eenderde niet tevreden met de loopbaanperspectieven en de scholingsfaciliteiten. Aangenomen dat er voor deze medewerkers weinig loopbaanperspectieven liggen binnen de apotheekbranche, zou dit er op kunnen duiden dat deze medewerkers het idee hebben dat ze in hun huidige functie enigszins vast zitten. Ook is een relatief grote groep administratief en secretarieel medewerkers niet tevreden over het leidinggeven door de apotheker (30\%). 


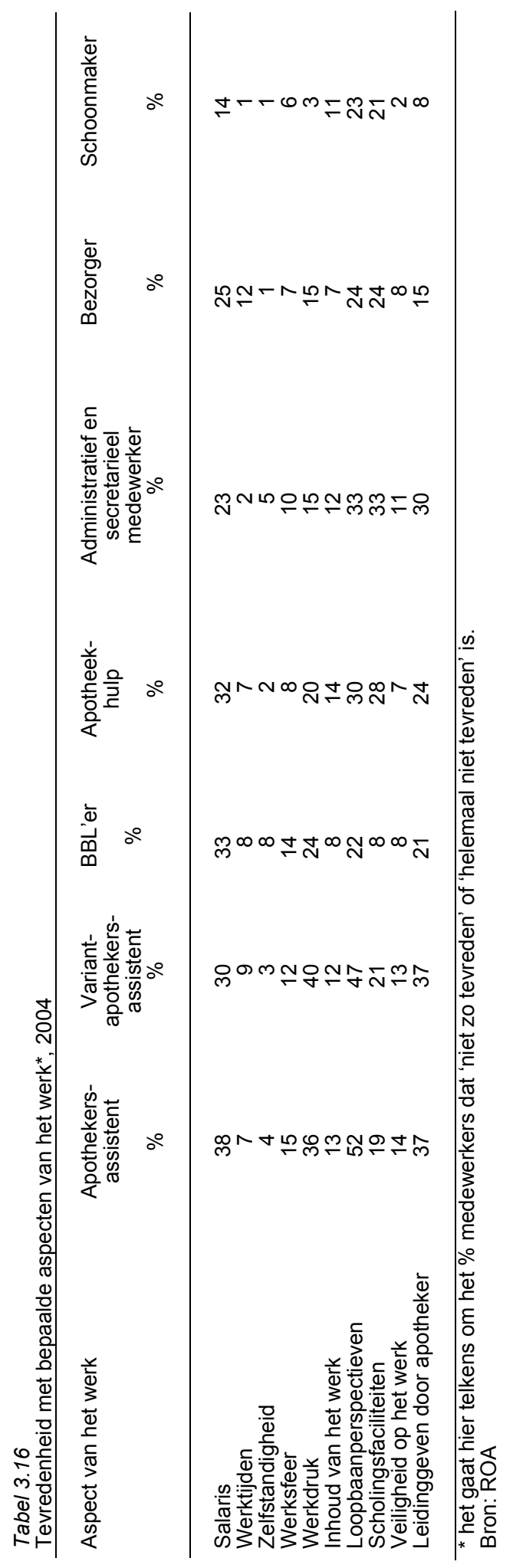




\section{Competenties van apotheekmedewerkers}

In dit hoofdstuk wordt ingegaan op de vraag in hoeverre apotheekmedewerkers zichzelf competent achten op de verschillende aspecten van het werk in de openbare apotheek. Ook wordt besproken of het oordeel van de medewerkers over hun eigen competentieniveau verschilt van het oordeel van de apothekers, en of bepaalde groepen medewerkers competenter zijn dan andere. Daarnaast wordt aangegeven op welke wijze de apothekersassistenten denken hun competenties het beste op peil te kunnen houden. Ten slotte wordt ingegaan op de vraag of de apotheken er in slagen goede medewerkers te 'binden en boeien'.

\subsection{Competenties}

Apotheekmedewerkers moeten over verschillende competenties beschikken om hun werk goed uit te kunnen oefenen. Tabel 4.1 laat zien hoe de apotheekmedewerkers hun eigen competentieniveau inschatten. Daarbij wordt een onderscheid gemaakt tussen competenties op het terrein van algemene vaardigheden (zoals communicatieve vaardigheden, zelfstandigheid en stressbestendigheid), vakkennis en -vaardigheden (zoals kennis van geneesmiddelen en ziektebeelden) en andere specifieke vaardigheden (bijvoorbeeld secretariële vaardigheden). ${ }^{22}$ Uit de tabel blijkt duidelijk dat de apothekersassistenten over het algemeen een erg positief beeld hebben van hun eigen competentieniveau. Zij geven zichzelf gemiddeld een 7,5 als rapportcijfer. Naar eigen oordeel scoren de apothekersassistenten het hoogst voor hun algemene vaardigheden (gemiddeld cijfer 7,8), maar ook hun eigen vakkennis en -vaardigheden waarderen ze hoog met een 7,4. Verder blijkt uit de tabel dat apothekersassistenten die werkzaam zijn in een van de specialistische variant-functies over de gehele linie gemiddeld hoger scoren dan de assistenten die werkzaam zijn in een 'gewone' functie. Dit geldt voor alle drie onderscheiden competentiedomeinen.

Ook de medewerkers die in de openbare apotheek werkzaam zijn in het kader van hun opleiding tot apothekersassistent volgens de beroepsbegeleidende leerweg (de BBL'ers) achten hun eigen competenties in het algemeen voldoende om goed te kunnen functioneren. Over de gehele linie is er vanzelfsprekend wel een duidelijk verschil tussen de competentiescores van de apothekersassistenten (gemiddeld 7,5) en de BBL'ers (gemiddeld 6,8). Goed beschouwd is dit verschil echter betrekkelijk gering. Mogelijk komt dat omdat BBL'ers een wat lager referentieniveau hebben dan de gediplomeerde assistenten, maar het wijst er ook op dat assistenten die de beroepsbegeleidende leerweg volgen, na het behalen van hun diploma direct goed inzetbaar zijn als apothekersassistent.

Tabel 4.1 laat verder zien dat apotheekhulpen in hun eigen ogen weinig onderdoen voor de apothekersassistenten wat hun algemene vaardigheden betreft. Daarentegen beseffen ze zeer goed dat ze niet competent zijn met betrekking tot de farma-

22. Tabel 4.2 geeft een volledig overzicht van de onderscheiden competenties. 
ceutische vakkennis en -vaardigheden waarover apothekersassistenten moeten kunnen beschikken.

Tabel 4.1

Beoordeling van eigen competentieniveau, 2004

\begin{tabular}{lcccc} 
& $\begin{array}{c}\text { Algemene } \\
\text { vaardig- } \\
\text { heden }\end{array}$ & $\begin{array}{c}\text { Vakkennis } \\
\text { en vaardig- } \\
\text { heden }\end{array}$ & $\begin{array}{c}\text { Andere } \\
\text { specifieke } \\
\text { vaardig- } \\
\text { heden }\end{array}$ & Totaal \\
\hline Apothekersassistent & 7,8 & 7,4 & 6,8 & 7,5 \\
Apothekersassistent variant FPZ & 8,0 & 7,7 & 7,1 & 7,7 \\
Apothekersassistent variant coördinerend & 8,0 & 7,6 & 7,4 & 7,7 \\
Apothekersassistent variant kwaliteitszorg & 8,0 & 7,6 & 7,3 & 7,7 \\
BBL'er & 7,4 & 6,6 & 6,1 & 6,8 \\
Apotheekhulp & 7,7 & 4,8 & 6,0 & 6,2 \\
Administratief en secretarieel medewerk. & 8,0 & 4,3 & 5,6 & 6,0 \\
Bezorger & 7,9 & 3,2 & 3,7 & 5,2 \\
Schoonmaker & 7,8 & $\cdot$ & $\cdot$ & 4,6 \\
\hline
\end{tabular}

= niet berekend

Bron: ROA

De bezorgers die werkzaam zijn in de apotheekbranche blijken overduidelijk weinig notie te hebben van de farmaceutische kennis en vaardigheden waarover apothekersassistenten moeten beschikken. Hetzelfde geldt in iets mindere mate voor de administratief en secretarieel medewerkers. Het is dan ook duidelijk dat deze medewerkers op dit terrein beter geen werkzaamheden kunnen verrichten.

In tabel 4.2 staan de rapportcijfers voor de specifieke competenties die ter beoordeling aan de apotheekmedewerkers zijn voorgelegd. De tabel laat zien dat 'gewone' apothekersassistenten zichzelf voor 14 van de 18 onderscheiden competenties gemiddeld een cijfer boven de 7 geven. Ten aanzien van hun zelfstandigheid, nauwkeurigheid/zorgvuldigheid en omgang/samenwerking met collega's ligt het gemiddelde waarderingscijfer zelfs boven de 8 . Daarentegen geven de assistenten zichzelf relatief lage cijfers voor:

- secretariële werkzaamheden $(6,5)$;

- het realiseren, bewaken en bevorderen van kwaliteitsbeleid $(6,6)$;

- leidinggeven $(6,6)$;

- kennis van wet- en regelgeving $(6,7)$.

Deze relatief lagere cijfers ondersteunen ook de verticale functiedifferentiatie die op basis van het nieuwe functiewaarderingssysteem in de apotheekbranche is doorgevoerd. Secretariële werkzaamheden kunnen veel beter door administratief en secretarieel medewerkers worden uitgevoerd (gemiddeld rapportcijfer 7,3). Het realiseren, bewaken en bevorderen van kwaliteitsbeleid past beter bij de assistenten die zich hierin specialiseren (gemiddeld rapportcijfer 7,8), terwijl de assistenten die werkzaam zijn in een coördinerende functie hoger scoren qua leidinggevende capaciteiten (gemiddeld rapportcijfer 7,5). Daarentegen blijkt geen van de drie categorieën van de variant-assistenten zich duidelijk te onderscheiden in hun kennis van wet- en regelgeving, al liggen de competentiescores voor alle drie soorten variantassistenten wel iets hoger dan bij de 'gewone' apothekersassistenten. 
In het algemeen geven overigens slechts weinig apothekersassistenten zichzelf een onvoldoende voor een bepaald competentie. Zo vindt slechts één op de veertig assistenten zichzelf onvoldoende stressbestendig en geeft $4 \%$ zichzelf een onvoldoende voor hun kennis van ziektebeelden. Duidelijk meer assistenten geven zichzelf een onvoldoende voor hun kennis van wet- en regelgeving. Ook vindt $13 \%$ van de apothekersassistenten zichzelf onvoldoende competent om leiding te geven, tegenover $7,5 \%$ van de assistenten in de variant FPZ en opvallend genoeg nog $4 \%$ van de assistenten in de variant coördinerend. Opmerkelijk is ook dat slechts $2 \%$ van de apothekersassistenten zichzelf een onvoldoende geeft voor hun computervaardigheden. Dit geeft duidelijk aan dat het werken met ICT in de apotheekbranche gemeengoed is geworden.

Ten slotte valt op dat een relatief grote groep assistenten zichzelf onvoldoende competent acht om secretariële werkzaamheden te verrichten. Dit is het geval bij maar liefst $16 \%$ van de 'gewone' assistenten en bij $10 \%$ van de variant-assistenten. Dit wijst er op dat nogal wat assistenten er baat bij hebben wanneer dergelijke werkzaamheden zoveel mogelijk door administratief en secretarieel medewerkers worden uitgevoerd.

Voor een aantal competenties kan een vergelijking worden gemaakt met de rapportcijfers die de assistenten zichzelf in 2001 gaven. Zoals verwacht mocht worden zijn de verschillen niet groot. ${ }^{23}$ Wel is het opmerkelijk dat, terwijl de beoordeling van de algemene vaardigheden hetzelfde is gebleven, de assistenten momenteel met name hun vakkennis hoger inschatten. Zo neemt het rapportcijfer voor de kennis van geneesmiddelen/zelfzorgartikelen toe van 7,2 naar 7,5 en de kennis van ziektebeelden van 6,7 naar 7,0. De assistenten die werkzaam zijn in een van de drie variant-functies scoren voor vrijwel alle specifieke competenties hoger dan de 'gewone' assistenten. Dit is alleen niet het geval voor de omgang en samenwerking met collega's. Ook blijken assistenten die werkzaam zijn in een coördinerende functie niet competenter te zijn in het recepteren van geneesmiddelen dan de 'gewone' assistenten.

Tabel 4.2 laat verder zien dat BBL'ers zichzelf alleen voor leidinggeven een duidelijke onvoldoende geven. Ook vinden ze vaak dat ze nog veel te leren hebben op het terrein van wet- en regelgeving, het realiseren, bewaken en bevorderen van kwaliteitsbeleid en secretariële werkzaamheden. Daarnaast zijn de verschillen tussen hun competentieniveau en het niveau van de apothekersassistenten vooral groot bij de kennis van geneesmiddelen/zelfzorgartikelen, het dispenseren (afleveren) van geneesmiddelen, de kennis van ziektebeelden en de zelfstandigheid van werken.

23. Hieruit blijkt ook dat de beoordeling van het eigen competentieniveau een vrij robuust beeld geeft van het competentieniveau van de apotheekmedewerkers. 


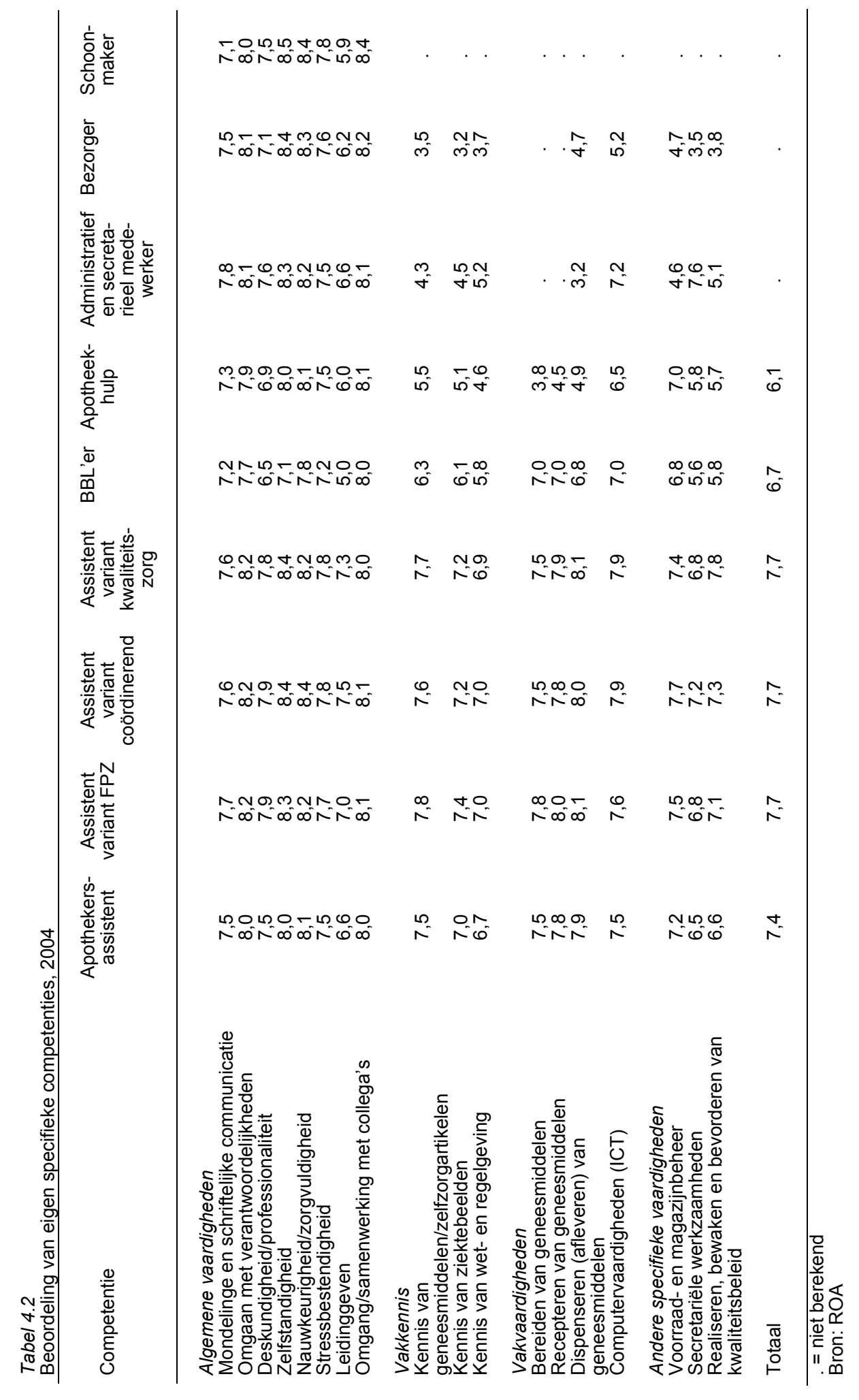


Uit de specifieke competentiescores van de apotheekhulpen blijkt dat het inzetten van apotheekhulpen vooral efficiënt is wanneer er een beroep wordt gedaan op hun algemene vaardigheden (bijvoorbeeld zelfstandigheid, nauwkeurigheid, mondelinge en schriftelijke communicatie en stressbestendigheid) en hun specifieke vaardigheden op het terrein van het voorraad- en magazijnbeheer.

\section{Eigen oordeel tegenover oordeel apothekers}

Tabel 4.3 vergelijkt de gemiddelde competentiescores die de apothekersassistenten zichzelf geven, met de rapportcijfers die de apothekers hen voor dezelfde competenties geven. Hoewel de apothekers ook een positief beeld hebben van de competenties van hun assistenten, beoordelen de assistenten hun eigen competentieniveau over de gehele linie wat positiever dan de apothekers. Het is opmerkelijk dat de verschillen het grootst zijn bij enkele algemene vaardigheden: zelfstandigheid, nauwkeurigheid/zorgvuldigheid, omgaan met verantwoordelijkheden en de omgang en samenwerking met collega's. Ook zijn de verschillen in de waardering voor de vakvaardigheden wat groter dan bij de vakkennis. Zeer opmerkelijk is ten slotte dat de apothekers een positiever beeld hebben van het competentieniveau van hun assistenten met betrekking tot het realiseren, bewaken en bevorderen van kwaliteitsbeleid, dan de assistenten zelf. Hetzelfde geldt voor het competentieniveau met betrekking tot de secretariële werkzaamheden. Dit zou er op kunnen wijzen dat apothekers de problemen die hun assistenten op deze terreinen in hun werk ervaren enigszins onderschatten.

\section{Het competentieniveau van herintreders en schoolverlaters}

De herintreders die apotheken de afgelopen jaren als apothekersassistent hebben aangetrokken, blijken zichzelf over de gehele linie iets lagere rapportcijfers te geven dan de (overige) assistenten die reeds langer in de apotheek werkzaam zijn. Herintreders hebben in vergelijking met de overige assistenten met name een wat minder gunstig beeld van hun computervaardigheden (gemiddeld 7,0 versus 7,6 ) en hun competenties op het terrein van voorraad- en magazijnbeheer en secretariële werkzaamheden (zie tabel 4.4). Daarnaast scoren ze duidelijk lager met betrekking tot hun deskundigheid/professionaliteit, zelfstandigheid, kennis van geneesmiddelen en zelfzorgartikelen, kennis van wet- en regelgeving en het realiseren, bewaken en bevorderen van kwaliteitsbeleid.

Bij de apotheekhulpen zijn de verschillen tussen herintreders en andere hulpen overigens minimaal. Wel scoren herintreders wat lager ten aanzien van hun zelfstandigheid. Daarentegen achten zij zich duidelijk meer competent in secretariële werkzaamheden dan de overige apotheekhulpen. Bij de bezorgers scoren de herintreders bij de algemene vaardigheden wat hoger dan de overige bezorgers. Bij de administratief en secretarieel medewerkers scoren de herintreders op enkele punten wat lager dan de overige administratief en secretarieel medewerkers. Dit geldt met name voor hun zelfstandigheid en leidinggeven. Daar staat tegenover dat ze op andere punten weer hoger scoren: mondelinge en schriftelijke communicatie en secretariële werkzaamheden. 
Tabel 4.3

Rapportcijfers voor specifieke competenties van apothekersassistenten: eigen oordeel en oordeel apothekers, 2004

\begin{tabular}{ll} 
Competentie & $\begin{array}{l}\text { Oordeel Oordeel } \\
\text { apothekers- apotheker } \\
\text { assistent }\end{array}$ \\
\hline
\end{tabular}

Algemene vaardigheden

Mondelinge en schriftelijke communicatie

Omgaan met verantwoordelijkheden

Deskundigheid/professionaliteit

Zelfstandigheid

Nauwkeurigheid/zorgvuldigheid

Stressbestendigheid

Leidinggeven

Omgang/samenwerking met collega's

$\begin{array}{ll}7,5 & 7, \\ 8,0 & 7,5 \\ 7,5 & 7, \\ 8,0 & 7,5 \\ 8,1 & 7, \\ 7,5 & 7,3 \\ 6,6 & 6, \\ 8,0 & 7,6\end{array}$

Vakkennis

Kennis van geneesmiddelen/zelfzorgartikelen

Kennis van ziektebeelden

$7,5 \quad 7,3$

Kennis van wet- en regelgeving

$\begin{array}{ll}7,0 & 6,8 \\ 6,7 & 6,7\end{array}$

Vakvaardigheden

Bereiden van geneesmiddelen

Recepteren van geneesmiddelen

Dispenseren (afleveren) van geneesmiddelen

Computervaardigheden (ICT)

$\begin{array}{ll}7,5 & 7,3 \\ 7,8 & 7,5 \\ 7,9 & 7,6 \\ 7,5 & 7,3\end{array}$

Andere specifieke vaardigheden

Voorraad- en magazijnbeheer

Secretariële werkzaamheden

$7,2 \quad 7,1$

Realiseren, bewaken en bevorderen van kwaliteitsbeleid

$6,5 \quad 6,7$

Totaal

$7,5 \quad 7,2$

Bron: ROA

De schoolverlaters die de apotheken de afgelopen jaren als apothekersassistent hebben aangetrokken geven zichzelf gemiddeld een net iets hoger cijfer voor hun competenties dan de herintreders (gemiddeld 7,3 versus 7,2). Voor wat betreft hun algemene vaardigheden scoren ze echter lager dan de herintreders. Het verschil is het grootst bij het leidinggeven (6,1 versus 6,6$)$. Voor hun vakvaardigheden en andere specifieke vaardigheden geven ze zichzelf daarentegen gemiddeld wat hogere cijfers. Dit is met name het gevolg bij hun computervaardigheden. Hiervoor scoren ze gemiddeld een 7,8, tegenover een 7,0 voor de herintreders en een 7,6 voor de apothekersassistenten die reeds langer in de apotheek werkzaam zijn. 
Tabel 4.4

Rapportcijfers voor specifieke competenties van herintreders, schoolverlaters en overige apothekersassistenten, 2004

\begin{tabular}{|c|c|c|c|}
\hline Competentie & Herintreder & Schoolverlater & $\begin{array}{l}\text { Overige } \\
\text { apothekers- } \\
\text { assistent }\end{array}$ \\
\hline \multicolumn{4}{|l|}{ Algemene vaardigheden } \\
\hline Mondelinge en schriftelijke communicatie & 7,5 & 7,4 & 7,6 \\
\hline Omgaan met verantwoordelijkheden & 7,9 & 7,7 & 8,0 \\
\hline Deskundigheid/professionaliteit & 7,3 & 7,2 & 7,7 \\
\hline Zelfstandigheid & 7,8 & 7,7 & 8,2 \\
\hline Nauwkeurigheid/zorgvuldigheid & 8,1 & 8,0 & 8,2 \\
\hline Stressbestendigheid & 7,5 & 7,2 & 7,5 \\
\hline Leidinggeven & 6,6 & 6,1 & 6,7 \\
\hline Omgang/samenwerking met collega's & 8,0 & 8,1 & 8,0 \\
\hline \multicolumn{4}{|l|}{ Vakkennis } \\
\hline Kennis van geneesmiddelen/zelfzorgartikelen & 7,3 & 7,3 & 7,6 \\
\hline Kennis van ziektebeelden & 6,9 & 6,8 & 7,1 \\
\hline Kennis van wet- en regelgeving & 6,5 & 6,6 & 6,8 \\
\hline \multicolumn{4}{|l|}{ Vakvaardigheden } \\
\hline Bereiden van geneesmiddelen & 7,3 & 7,5 & 7,5 \\
\hline Recepteren van geneesmiddelen & 7,6 & 7,7 & 7,9 \\
\hline Dispenseren (afleveren) van geneesmiddelen & 7,8 & 7,8 & 8,0 \\
\hline Computervaardigheden (ICT) & 7,0 & 7,8 & 7,6 \\
\hline \multicolumn{4}{|l|}{ Andere specifieke vaardigheden } \\
\hline Voorraad- en magazijnbeheer & 6,8 & 7,0 & 7,3 \\
\hline Secretariële werkzaamheden & 6,1 & 6,3 & 6,6 \\
\hline kwaliteitsbeleid & 6,4 & 6,4 & 6,7 \\
\hline Totaal & 7,2 & 7,3 & 7,5 \\
\hline
\end{tabular}

Bron: ROA

\section{Ervaring en competentieniveau}

In hoeverre wordt het competentieniveau van apothekersassistenten nu beïnvloed door de werkervaring die men heeft? En wat is het effect van een loopbaanonderbreking op iemand's competentieniveau? In tabel 4.5 wordt dit in beeld gebracht. De eerste kolom geeft aan of het aantal jaren dat iemand ervaring heeft als apothekersassistent invloed heeft op de mate waarin de assistent zichzelf op een bepaald gebied meer competent acht. De tabel laat zien dat apothekersassistenten met meer werkervaring zichzelf significant hogere cijfers geven voor een aantal algemene competenties, waaronder hun professionaliteit, zelfstandigheid en stressbestendigheid. Daarentegen achten ze zichzelf minder competent in de omgang en samenwerking met collega's dan assistenten met minder werkervaring. Ook scoren ze lager op hun computervaardigheden en vaardigheden met betrekking tot voorraad en magazijnbeheer.

Het is eveneens opmerkelijk dat de meer ervaren assistenten zichzelf niet competenter achten in hun vakkennis en vakvaardigheden dan de assistenten met minder werkervaring. Dit wijst er op dat de voor het werk vereiste vakkennis en vakvaardigheden tamelijk snel veranderen. Assistenten die meer recent hun vakopleiding hebben gevolgd verwerven hierdoor in hun opleiding meer actuele vakkennis. Het feit 
Tabel 4.5

Relatie tussen werkervaring, loopbaanonderbreking en competenties bij apothekersassistenten en variant-apothekersassistenten, 2004*

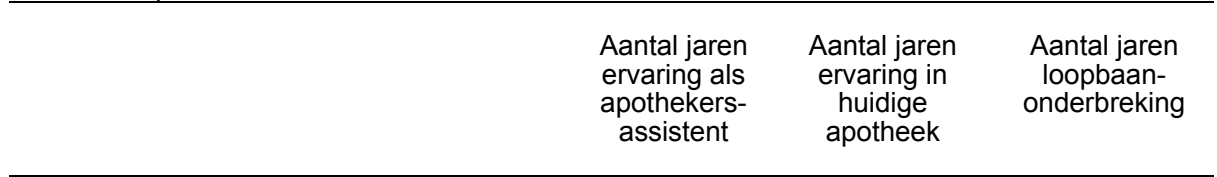

\section{Apothekersassistent}

Mondelinge en schriftelijke communicatie

Omgaan met verantwoordelijkheden

Deskundigheid/professionaliteit

Zelfstandigheid

Stressbestendigheid

Leidinggeven

Omgang/samenwerking met collega's

Kennis van geneesmiddelen/

zelfzorgartikelen

Kennis van ziektebeelden

Kennis van wet- en regelgeving

Bereiden van geneesmiddelen

Recepteren van geneesmiddelen

Dispenseren van geneesmiddelen

Computervaardigheden

Voorraad en magazijnbeheer

Variant-apothekersassistent

Omgaan met verantwoordelijkheden

Deskundigheid/professionaliteit

Zelfstandigheid

Stressbestendigheid

Leidinggeven

Kennis van geneesmiddelen/

zelfzorgartikelen

Kennis van ziektebeelden

Kennis van wet- en regelgeving

Recepteren van geneesmiddelen

Dispenseren van geneesmiddelen

Voorraad en magazijnbeheer

Secretariële werkzaamheden

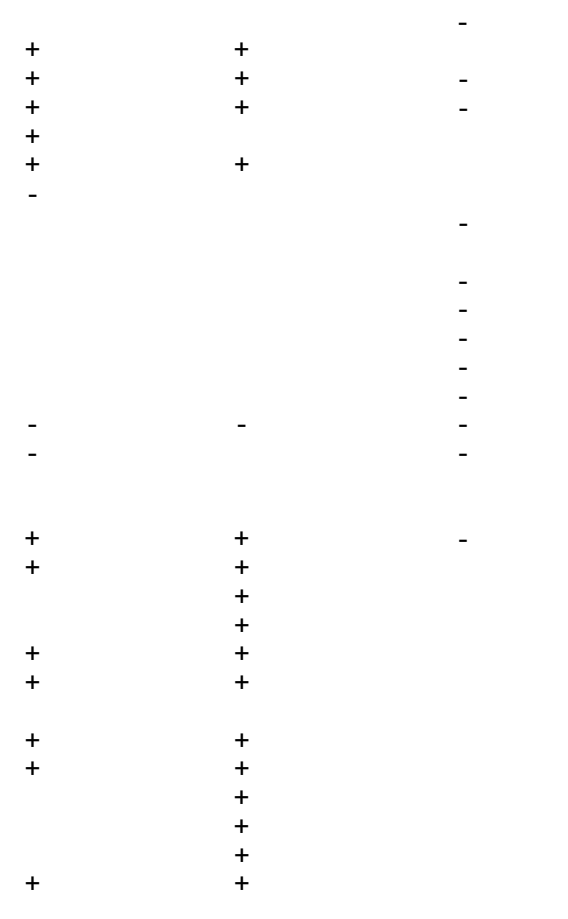

* In de tabel worden alleen de significante relaties weergegeven.

$+=$ positief verband; - = negatief verband

Bron: ROA

dat er in het niveau van de vakkennis en vakvaardigheden van de meer en minder ervaren apothekersassistenten geen signifcant verschil is, wijst er echter ook op dat de meer ervaren assistenten hun vakkennis en vakvaardigheden gedurende hun loopbaan goed op peil weten te houden. Dit geldt in nog veel sterkere mate voor de variant-apothekersassistenten. De variant-assistenten met meer werkervaring zijn op een groot aantal terreinen competenter dan de variant-assistenten met minder werkervaring. Hierbij gaat het niet alleen om enkele algemene competenties, maar ook om de vakspecifieke kennis van geneesmiddelen en zelfzorgartikelen, ziektebeelden en wet- en regelgeving.

In tabel 4.5 wordt aangeven of assistenten met meer werkervaring in de apotheek waar ze momenteel werkzaam zijn, op bepaalde terreinen competenter zijn. Hieruit komt vrijwel hetzelfde beeld naar voren als bij het aantal jaren werkervaring als assistent in het algemeen. De laatste kolom van tabel 4.5 laat zien dat assistenten die hun loopbaan langere tijd hebben onderbroken hun competentieniveau lager 
waarderen. Dit geldt zowel voor hun algemene vaardigheden als voor hun vakkennis en vakvaardigheden. Dit wijst er op dat langdurige loopbaanonderbrekingen over de gehele linie tot een duidelijke terugval van het competentieniveau van assistenten leiden. Bij de variant-assistenten blijken langdurige loopbaanonderbrekingen alleen een negatief effect te hebben op het kunnen omgaan met verantwoordelijkheden. Hierbij moet echter opgemerkt worden dat het aantal variant-assistenten dat de loopbaan langere tijd heeft onderbroken vrij klein is.

Tabel 4.6

Relatie tussen werkervaring en competentieniveau bij de overige apotheekmedewerkers, $2004^{*}$

\begin{tabular}{|c|c|c|}
\hline & $\begin{array}{l}\text { Aantal jaren werk- } \\
\text { ervaring }{ }^{* *}\end{array}$ & $\begin{array}{l}\text { Aantal jaren } \\
\text { ervaring in } \\
\text { huidige } \\
\text { apotheek }\end{array}$ \\
\hline \multicolumn{3}{|l|}{ Apotheekhulp } \\
\hline Kennis van wet- en regelgeving & - & \\
\hline Bereiden van geneesmiddelen & - & \\
\hline Recepteren van geneesmiddelen & - & \\
\hline Computervaardigheden & - & \\
\hline Voorraad en magazijnbeheer & + & \\
\hline \multicolumn{3}{|l|}{ BBL'er } \\
\hline Mondelinge en schriftelijke communicatie & + & \\
\hline Omgaan met verantwoordelijkheden & + & \\
\hline \multicolumn{3}{|l|}{ Administratief en secretarieel medewerker } \\
\hline Deskundigheid/professionaliteit & + & \\
\hline Voorraad en magazijnbeheer & - & - \\
\hline \multicolumn{3}{|l|}{ Bezorger } \\
\hline Stressbestendigheid & + & \\
\hline Kennis van geneesmiddelen/zelfzorgartikelen & & + \\
\hline Kennis van ziektebeelden & & + \\
\hline Kennis van wet- en regelgeving & & + \\
\hline Voorraad en magazijnbeheer & + & + \\
\hline \multicolumn{3}{|l|}{ Schoonmaker } \\
\hline Omgaan met verantwoordelijkheden & & - \\
\hline Zelfstandigheid & & - \\
\hline
\end{tabular}

* In de tabel worden alleen de significante relaties weergegeven.

** In apotheekbranche of daarbuiten

$+=$ positief verband; - = negatief verband

Bron: ROA

Tabel 4.6 laat zien of bij de overige apotheekmedewerkers degenen met meer werkervaring op bepaalde terreinen competenter zijn dan medewerkers met minder ervaring. Uit de tabel blijkt dat bij de apotheekhulpen, BBL'ers en administratief en secretarieel medewerkers vooral de totale werkervaring van de medewerkers effect heeft op het competentieniveau. Daarbij is het opvallend dat apotheekhulpen met een langere werkervaring lager scoren qua vakvaardigheden, kennis van wet- en regelgeving en computervaardigheden dan de apotheekhulpen met minder werkervaring. Alleen op het terrein van voorraad- en magazijnbeheer scoren de meer ervaren apotheekhulpen hoger. BBL'ers met meer werkervaring scoren met name hoger voor hun mondelinge en schriftelijke communicatie en het omgaan met verantwoordelijkheden. Daarentegen zijn er geen significante verschillen tussen het competentieniveau van de apotheekhulpen die reeds langer in hun huidige apotheek 
werkzaam zijn en de apotheekhulpen met minder ervaringsjaren in de huidige apotheek.

Bij de bezorgers heeft met name de werkervaring in de huidige apotheek een positief effect op hun competentieniveau. Hierbij gaat het vooral om hun vakkennis op farmaceutisch gebied. Schoonmakers die al langer bij de huidige apotheek werkzaam zijn, vinden zichzelf minder zelfstandig en minder goed omgaan met verantwoordelijkheden dan de schoonmakers die korter bij de apotheek werkzaam zijn.

\subsection{Het op peil houden van het competentieniveau}

In tabel 4.7 wordt een overzicht gegeven van de wijze waarop apothekersassistenten een viertal voor hun werk belangrijke competenties het beste op peil denken te kunnen houden. Daarbij worden zes verschillende leerwegen onderscheiden:

- het volgen van cursussen;

- het volgen van teamtrainingen;

- e-learning: cursus via computer en/of internet;

- zelfstudie via schriftelijk materiaal;

- leren op de werkplek;

- leren van collega's.

Tabel 4.7

Manieren om competenties het beste op peil te kunnen houden volgens apothekersassistenten en variant-apothekersassistenten, 2004

\begin{tabular}{|c|c|c|c|c|}
\hline & $\begin{array}{c}\text { Mondelinge } \\
\text { en schriftelijke } \\
\text { communicatie } \\
\%\end{array}$ & $\begin{array}{c}\text { Kennis van } \\
\text { genees- } \\
\text { middelen/ } \\
\text { zelfzorg- } \\
\text { artikelen } \\
\%\end{array}$ & $\begin{array}{l}\text { Bereiden } \\
\text { van genees- } \\
\text { middelen } \\
\\
\%\end{array}$ & $\begin{array}{c}\text { Computer- } \\
\text { vaardig- } \\
\text { heden } \\
\\
\%\end{array}$ \\
\hline \multicolumn{5}{|l|}{ Apothekersassistent } \\
\hline Cursus & 21 & 58 & 20 & 33 \\
\hline Teamtraining & 31 & 6 & 2 & 5 \\
\hline E-learning & 2 & 9 & 1 & 12 \\
\hline $\begin{array}{l}\text { Zelfstudie via schriftelijk } \\
\text { materiaal }\end{array}$ & 2 & 11 & 3 & 2 \\
\hline Leren op de werkplek & 38 & 14 & 61 & 38 \\
\hline Leren van collega's & 6 & 2 & 13 & 10 \\
\hline \multicolumn{5}{|c|}{ Variant-apothekersassistent } \\
\hline Cursus & 24 & 56 & 22 & 36 \\
\hline Teamtraining & 36 & 5 & 2 & 2 \\
\hline E-learning & 4 & 13 & 1 & 15 \\
\hline $\begin{array}{l}\text { Zelfstudie via schriftelijk } \\
\text { materiaal }\end{array}$ & 3 & 14 & 3 & 3 \\
\hline Leren op de werkplek & 31 & 13 & 63 & 37 \\
\hline Leren van collega's & 3 & 1 & 11 & 7 \\
\hline
\end{tabular}

Bron: ROA

Uit de tabel blijkt dat er tussen de 'gewone' apothekersassistenten en de assistenten die werkzaam zijn in een variant-functie geen grote verschillen zijn in de wijze waarop ze denken een bepaalde competentie het beste op peil te kunnen houden. Het verbeteren van mondelinge en schriftelijke communicatie denkt men het beste op de werkplek zelf te kunnen leren, of door middel van teamtrainingen. Het is opmerkelijk 52 
dat de variant-assistenten hierbij het meest opteren voor teamtrainingen, terwijl de 'gewone' assistenten het meest verwachten van het leren op de werkplek.

Daarentegen denkt meer dan de helft van de assistenten dat ze hun kennis van geneesmiddelen en zelfzorgartikelen het beste op peil kunnen houden door het volgen van cursussen. Sommigen vinden dat men dit het beste op de werkplek zelf kan leren $(14 \%)$, of door zelfstudie via schriftelijk materiaal (11\%). Daarnaast vindt $13 \%$ van de variant-assistenten dat e-learning goede mogelijkheden biedt om hun kennis van geneesmiddelen en zelfzorgartikelen op peil te houden.

Het op peil houden van de competenties met betrekking tot het bereiden van geneesmiddelen kan volgens de meeste assistenten het beste op de werkplek zelf worden geleerd. Een op de vijf assistenten vindt echter dat het volgen van een cursus meer vruchten afwerpt.

Ten slotte kunnen computervaardigheden volgens ruim eenderde van de assistenten eveneens het beste op de werkplek worden aangeleerd. Een bijna even grote groep geeft daarentegen aan het volgen van een cursus de meest geschikte leerweg te vinden.

Al met al kan geconcludeerd worden dat competenties volgens de apothekersassistenten het beste op peil gehouden kunnen worden door te leren op de werkplek. Alleen voor het op peil houden van de kennis van geneesmiddelen en zelfzorgartikelen is het volgen van een cursus de meest geschikte leerweg. Daarnaast is er voor de andere onderscheiden competenties ook een aanzienlijke groep assistenten die vindt dat ze deze competenties het beste op peil kunnen houden door het volgen van cursussen. Teamtrainingen zijn daarentegen volgens de assistenten alleen optimaal voor het verbeteren van de mondelinge en schriftelijke communicatie. Van e-learning wordt in het algemeen nog weinig verwacht. Deze leerweg lijkt het meeste perspectief te bieden voor het op peil houden van computervaardigheden en de kennis van geneesmiddelen en zelfzorgartikelen. Opmerkelijk is wel dat de variantassistenten iets vaker de voorkeur geven aan e-learning dan de assistenten die werkzaam zijn in een gewone functie.

\subsection{Competenties, werkdruk, ziekteverzuim en tevredenheid}

Om goed te kunnen functioneren is het voor een apotheek, net zoals voor iedere andere organisatie, van groot belang om medewerkers die goed presteren vast te houden. Men spreekt in dit verband wel van het belang om goed personeel te 'binden en boeien'. Daar staat tegenover dat het voor de kwaliteit van de apotheek juist goed is als medewerkers die matig presteren niet te lang bij de apotheek blijven werken. Om een indruk te krijgen in hoeverre apotheken erin slagen het juiste personeel te binden en boeien, zal in deze paragraaf worden ingegaan op de vraag of er relaties bestaan tussen de competentiescores van apotheekmedewerkers en de werkdruk die ze ervaren, hun ziekteverzuim en de tevredenheid met hun baan. 
Tabel 4.8 laat zien in hoeverre apotheekmedewerkers die hoog scoren voor een bepaalde competentie meer of minder werkdruk ervaren. Op dit punt zijn er twee mogelijkheden:

- $\quad$ Als een medewerker goed is op een bepaald gebied, dan vermindert dit de werkdruk, omdat men effectief kan werken.

- $\quad$ Als een medewerker goed is op een bepaald gebied, dan vergroot dit de werkdruk, omdat men hogere eisen aan zichzelf stelt.

Uit de tabel blijkt dat beide mogelijkheden zich voordoen. Met name iemands stressbestendigheid beperkt de ervaren werkdruk. Daarnaast ervaren apothekersassistenten en apotheekhulpen minder werkdruk wanneer zij beter zijn in het verrichten van secretariële werkzaamheden. Hetzelfde geldt voor de apothekersassistenten die goed zijn in het realiseren, bevorderen en bewaken van het kwaliteitsbeleid.

Tabel 4.8

Relatie tussen specifieke competenties en werkdruk van apotheekmedewerkers, 2004*

Werkdruk

Apothekersassistent
Stressbestendigheid
Secretariële werkzaamheden
Realiseren, bewaken en bevorderen van kwaliteitsbeleid
Variant-apothekersassistent
Kennis van ziektebeelden
Bereiden van geneesmiddelen
BBL'er
Bereiden van geneesmiddelen
Apotheekhulp
Omgaan met verantwoordelijkheden
Stressbestendigheid
Kennis van geneesmiddelen/zelfzorgartikelen
Kennis van ziektebeelden
Kennis van wet- en regelgeving
Bereiden van geneesmiddelen
Recepteren van geneesmiddelen
Dispenseren van geneesmiddelen
Secretariële werkzaamheden
Administratief en secretarieel medewerker
Voorraad- en magazijnbeheer
Bezorger
Deskundigheid/professionaliteit
Zelfstandigheid
Omgang/samenwerking met collega's
Kennis van geneesmiddelen/
zelfzorgartikelen
Kennis van wet- en regelgeving
Voorraad- en magazijnbeheer
Secretariële werkzaamheden

${ }^{*}$ In de tabel worden alleen de significante relaties weergegeven.

$+=$ positief verband; - = negatief verband

Bron: ROA

Bij verschillende andere competenties blijkt daarentegen dat medewerkers die er goed in zijn juist een grotere werkdruk ervaren. Dit is bijvoorbeeld het geval bij de variant-assistenten die goed scoren voor hun kennis van ziektebeelden en het 
bereiden van geneesmiddelen. Maar met name bij de apotheekhulpen blijkt er bij een groot aantal competenties een positieve samenhang te zijn tussen iemands competentieniveau en de ervaren werkdruk. Apotheekhulpen die vinden dat ze goed omgaan met verantwoordelijkheden, relatief veel vakkennis hebben en over goede vakspecifieke vaardigheden beschikken hebben vaker een hogere werkdruk. Dit wijst erop dat de apotheekhulpen die vrij goed zijn in hun vak nogal eens op hun tenen lopen. Hetzelfde doet zich voor bij de bezorgers. Ook hier geldt bij verschillende competenties dat degenen die hoog scoren, relatief veel werkdruk ervaren.

Tabel 4.9

Relatie tussen specifieke competenties en het ziekteverzuim van apotheekmedewerkers, $2004^{*}$

$\begin{array}{cc}\text { Aantal } & \begin{array}{c}\text { Aantal dagen } \\ \text { ziekteverzuim }\end{array} \\ \text { ziektemeldingen } & \end{array}$

\footnotetext{
Apothekersassistent

Mondelinge en schriftelijke communicatie

Stressbestendigheid

Bereiden van geneesmiddelen

Computervaardigheden

Voorraad en magazijnbeheer

Variant-apothekersassistent

Mondelinge en schriftelijke communicatie

Omgang/samenwerking met collega's

$B B L$ 'er

Mondelinge en schriftelijke communicatie

Stressbestendigheid

Omgang/samenwerking met collega's

Apotheekhulp

Stressbestendigheid

Omgang/samenwerking met collega's
}

ziektemeldingen

ziekteverzuim

Administratief en secretarieel medewerker

Stressbestendigheid

Bezorger

Stressbestendigheid

Secretariële werkzaamheden

Schoonmaker

Nauwkeurigheid/zorgvuldigheid

${ }^{*}$ In de tabel worden alleen de significante relaties weergegeven.

$+=$ positief verband; - = negatief verband

Bron: ROA

Het werken onder een hogere werkdruk vergroot het risico op langdurig ziekteverzuim. ${ }^{24}$ Daarom is ook gekeken of er een samenhang is tussen het competentieniveau van apotheekmedewerkers en het aantal ziekmeldingen. Daarnaast is onderzocht of er een relatie bestaat tussen het competentieniveau van medewerkers en het aantal dagen ziekteverzuim. Tabel 4.9 laat zien dat medewerkers in verschillende functies met een hoge score voor hun stressbestendigheid zich significant minder vaak ziek melden en minder dagen door ziekte hun werk verzuimen. Bij de variant-assistenten, BBL'ers en apotheekhulpen blijkt dat degenen die hoog scoren

24. A. de Grip en I. Sieben (2002), Werken in de openbare apotheek, ROA-R-2002/13, Maastricht, p. 56. 
voor hun omgang en samenwerking met collega's zich minder vaak ziek melden of minder langer ziek zijn. Dit zou er op kunnen wijzen dat als er problemen zijn in de samenwerking binnen het apotheekteam ${ }^{25}$, het ziekteverzuim in de apotheek.

Apothekersassistenten die goed zijn in het bereiden van geneesmiddelen, of die hoog scoren voor hun computervaardigheden, blijken zich relatief vaak ziek melden. Dit waren overigens geen competenties waarvoor er bij de apothekersassistenten sprake was van een samenhang met de ervaren werkdruk. Ook blijkt dat zowel bij de apotheekhulpen, als bij de variant-assistenten en de BBL'ers, dat degenen met een hoge score voor hun mondelinge en schriftelijke communicatie zich vaker ziek melden of langduriger ziek zijn. Ook hier was er geen significant verband tussen het competentieniveau en de ervaren werkdruk, zodat niet zonder meer gezegd kan worden dat het grotere aantal ziekmeldingen gerelateerd is aan de hoge eisen die medewerkers met hoge competentiescores aan zichzelf stellen.

\section{Tevredenheid}

Ten slotte wordt in deze paragraaf ingegaan op de relatie tussen het competentieniveau van de apotheekmedewerkers en hun tevredenheid met hun werk. Uit verschillende studies blijkt dat mensen die veel in hun mars hebben vaker ontevreden zijn met hun werk, omdat hun verwachtingen met betrekking tot hun ontplooiingskansen hoger liggen. Dit is zeker het geval wanneer het niveau van hun werk onvoldoende aansluit bij hun capaciteiten. ${ }^{26}$ De tevredenheid met het werk kan overigens van verschillende zaken afhangen. Daarbij spelen in de praktijk naast het 'matchen' van de inhoud van het werk met iemands capaciteiten en ambities, ook de salariëring en arbeidsomstandigheden een belangrijke rol.

Tabel 4.10 geeft voor de verschillende functiegroepen binnen de openbare apotheek een overzicht van de relaties tussen het niveau van de specifieke competenties en de tevredenheid met hun baan. De eerste kolom van de tabel laat zien of degenen die hoog scoren voor een bepaalde competentie over het algemeen meer of minder tevreden zijn met hun baan. In de volgende kolommen wordt ingezoomd op de vraag of degenen die hoog scoren op een specifieke competentie meer of minder tevreden zijn met bepaalde aspecten van hun baan. De tabel laat zien dat bij veel functies vooral degenen die beschikken over goede algemene competenties over het algemeen minder tevreden zijn met hun baan. De apothekersassistenten met een hoge score voor hun deskundigheid/professionaliteit en zelfstandigheid zijn echter juist meer tevreden met verschillende aspecten van hun functie. Deze assistenten blijken zowel meer tevreden te zijn met de inhoud van hun werk, als met het salaris en het loopbaanperspectief. Bovendien zijn deze assistenten meer tevreden over het leidinggeven door de apotheker. Daarentegen zijn de assistenten met een hoge

25. Aangenomen mag worden dat in dat geval apotheekmedewerkers zichzelf lagere cijfers geven voor hun omgang/samenwerking met collega's.

26. Zie bijvoorbeeld Y. Ganzach (1998), "Intelligence and Job Satisfaction", Academy of Management Journal, jaargang 41, p. 526-539 en M.C. Tsang, R.W. Rumberger en H.M. Levin (1991). "The Impact of Surplus Schooling on Work Productivity", Industrial Relations, 56 jaargang 30, p. 209-228. 


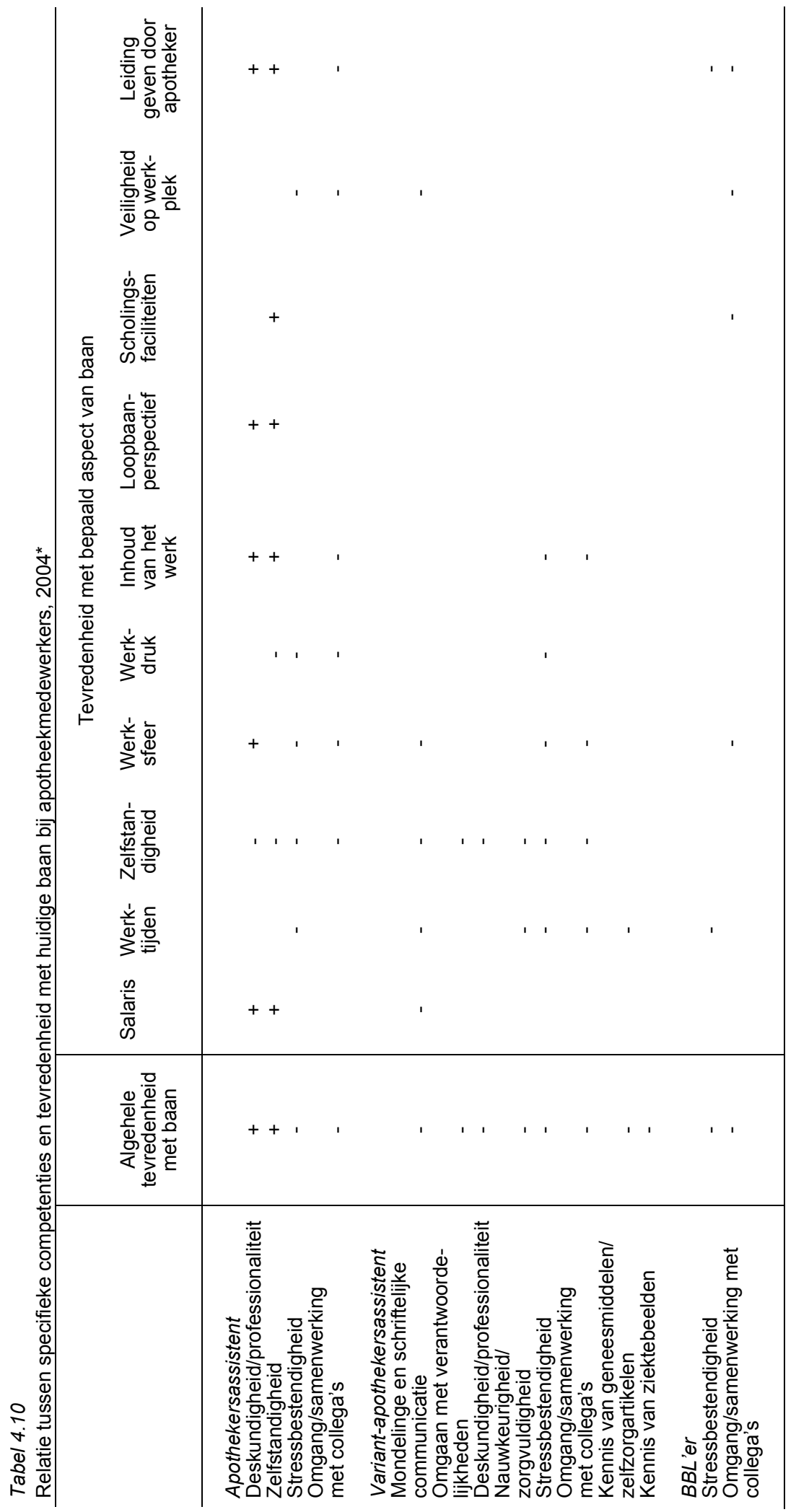




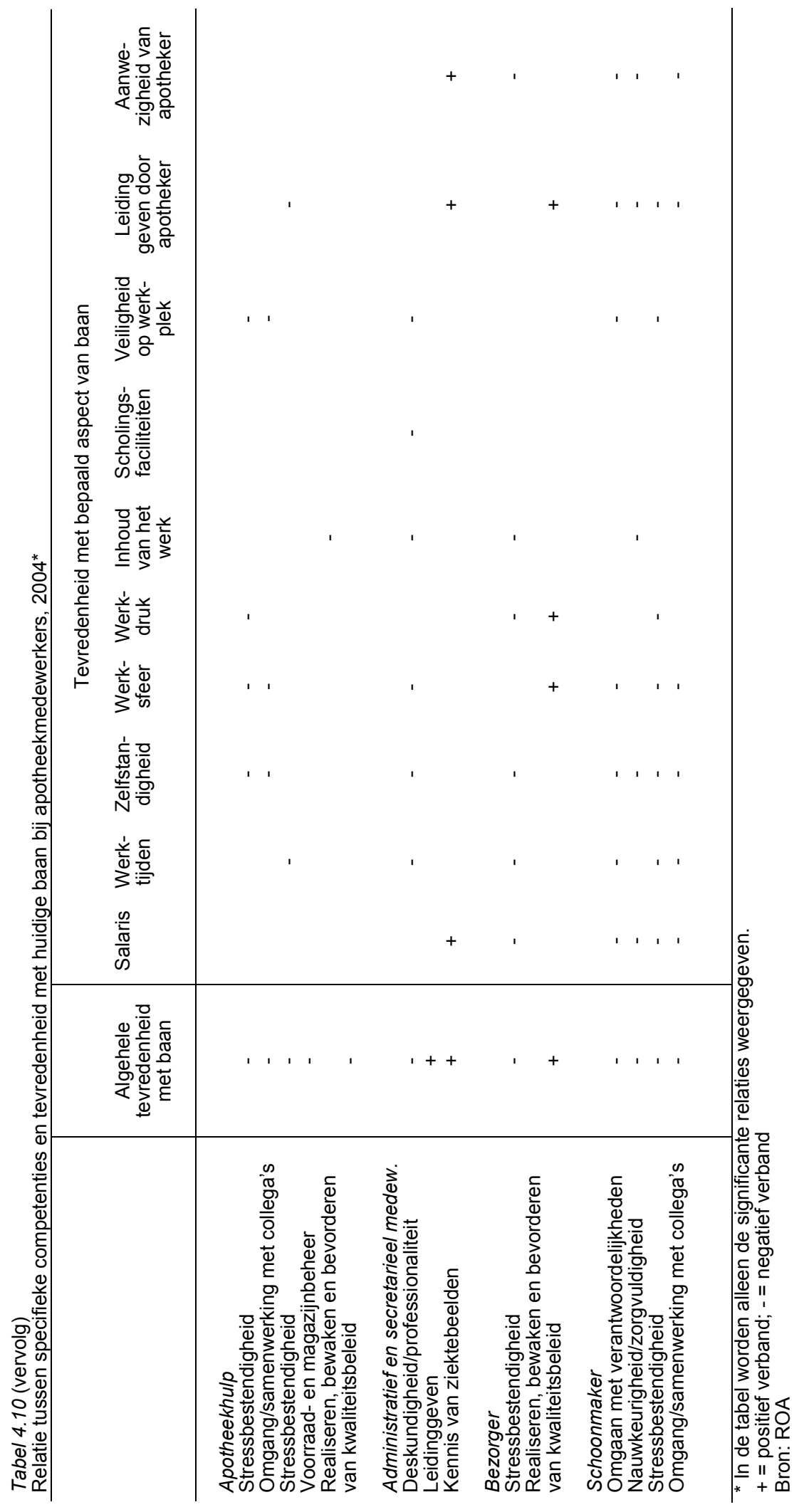


score voor hun deskundigheid minder tevreden over de zelfstandigheid waarmee ze hun werk kunnen uitvoeren.

Ook de variant-apothekersassistenten met hoge scores voor bepaalde competenties zijn met name minder tevreden over de mate waarin ze zelfstandig kunnen opereren. Dit wijst er op dat zowel in de 'gewone' functies als in de variant-functies de apothekersassistenten die zichzelf meer competent achten op bepaalde terreinen minder tevreden zijn met de vrijheidsgraden die ze in hun werk hebben. Daarnaast zijn de meest competente variant-assistenten vooral minder tevreden over de werktijden, de werksfeer en de inhoud van het werk. Ook bij de andere apotheekmedewerkers valt op dat degenen met hogere competentiescores vaker minder tevreden zijn over de zelfstandigheid waarmee ze hun werkzaamheden kunnen uitvoeren, terwijl vooral bij de apothekersassistenten, apotheekhulpen en schoonmakers degenen die relatief hoog scoren voor bepaalde competenties minder tevreden zijn over de werksfeer en de werkdruk. Ten slotte zijn vooral de schoonmakers met hogere competentiescores vaker ontevreden over hun salaris en werktijden, terwijl zij opmerkelijk genoeg ook minder tevreden zijn over het leidinggeven door de apotheker en de aanwezigheid van de apotheker. Dit zou er op kunnen wijzen dat zij vinden dat ze onvoldoende deel uitmaken van de organisatie.

\subsection{Competenties en loopbaanverwachtingen}

Als werknemers minder tevreden zijn, wil dit natuurlijk nog niet automatisch zeggen dat ze op zoek gaan naar een andere baan. Daarom zal in deze paragraaf worden nagegaan in hoeverre apothekersassistenten met een hoger competentieniveau actief op zoek zijn naar een andere baan. ${ }^{27}$ In aansluiting daarop zal worden ingegaan op de relatie tussen het competentieniveau en de loopbaanverwachtingen van de assistenten.

Tabel 4.11 laat zien dat apothekersassistenten die voor bepaalde competenties een hoger cijfer scoren minder vaak actief op zoek zijn naar een andere baan. Bovendien zijn zij minder vaak op zoek naar ander soort werk. Dit is zowel het geval bij een aantal algemene vaardigheden, als bij verschillende vakspecifieke competenties. Hieruit blijkt dat het in paragraaf 4.3 geconstateerde negatieve verband tussen het competentieniveau van assistenten en hun tevredenheid met hun baan niet betekent dat de apotheek deze assistenten niet aan de organisatie weet te binden. Dit zou erop kunnen wijzen dat de meer competente assistenten weliswaar minder tevreden zijn met hun werk, maar toch niet verwachten dat ze, wanneer ze ergens anders zouden gaan werken, er op vooruit zouden gaan. Het kan echter ook betekenen dat deze assistenten, ondanks dat ze minder tevreden zijn met hun huidige baan, sterk gebonden zijn aan hun huidige werkplek.

27. Deze informatie is alleen beschikbaar voor de apothekersassistenten. 
Tabel 4.11

Relatie tussen specifieke competenties en mogelijk personeelsverloop van apothekersassistenten, 2004*

$\begin{array}{cc}\begin{array}{c}\text { Actief op zoek } \\ \text { naar andere } \\ \text { functie }\end{array} & \begin{array}{c}\text { Actief op zoek naar } \\ \text { andere baan dan } \\ \text { apothekersassistent }\end{array}\end{array}$

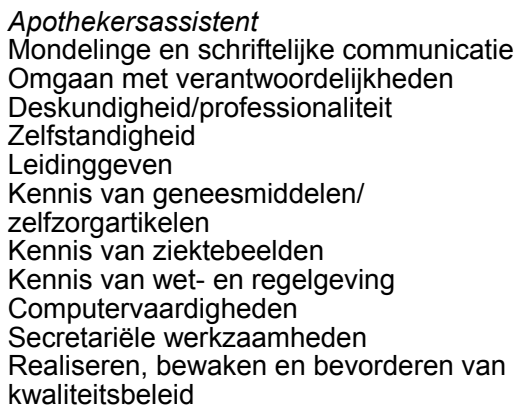

Bij de variant-apothekersassistenten kan er bij geen enkele competentie een negatief verband tussen hun competentieniveau en de mate waarin ze op zoek zijn naar ander werk worden vastgesteld. Opmerkelijk genoeg blijkt echter dat variantassistenten met een hoog cijfer voor hun omgang en samenwerking met collega's vaker op zoek zijn naar een andere functie en daarbij vooral ook denken aan ander soort werk. Dit zou er op kunnen wijzen dat deze assistenten hun samenwerkingsvaardigheden in hun functie als apothekersassistent onvoldoende tot hun recht vinden komen en daarom op zoek zijn naar ander werk.

Tabel 4.12 geeft een overzicht van de relaties tussen het competentieniveau van de apothekersassistenten en hun loopbaanverwachtingen. Hieruit komt een wat ander beeld naar voren dan uit tabel 4.11. Assistenten die relatief hoog scoren voor enkele algemene en/of vakspecifieke competenties verwachten vaker dat ze over 5 jaar niet meer werkzaam zijn in de apotheek waar ze momenteel werken. Degenen die hoog scoren op de omgang en samenwerking met collega's, bereiden van geneesmiddelen en vooraad- en magazijnbeheer denken ook vaker dat ze over 5 jaar niet meer werkzaam zijn als apothekersassistent. Daarentegen verwachten de assistenten met een hoger cijfer voor hun zelfstandigheid vaker dat ze over 5 jaar nog in dezelfde apotheek werkzaam zijn. Bij de variant-assistenten is dit ook het geval bij degenen die hoog scoren op hun computervaardigheden. 
Tabel 4.12

Relatie tussen specifieke competenties en loopbaanverwachtingen van apothekersassistenten, $2004^{*}$

Naar verwachting

over 5 jaar niet meer

werkzaam in huidige apotheek

Naar verwachting over 5 jaar niet meer

werkzaam als apothekersassistent

\section{Apothekersassistent \\ Zelfstandigheid}

Stressbestendigheid

Omgang/samenwerking met collega's

Bereiden van geneesmiddelen

Voorraad- en magazijnbeheer

-
+
+

$+$

Variant-apothekersassistent

Computervaardigheden

* In de tabel worden alleen de significante relaties weergegeven.

$+=$ positief verband; - = negatief verband

Bron: ROA 



\section{Scholing van apotheekmedewerkers}

In dit hoofdstuk wordt in kaart gebracht welke cursussen er door apotheekmedewerkers gevolgd worden. Daarnaast wordt nagegaan om welke redenen zij cursussen volgen en in hoeverre scholing ook echt het competentieniveau bevordert. Ook wordt er antwoord gegeven op de vraag aan welke cursussen medewerkers behoefte hebben. Ten slotte komt het HRM-beleid rond scholing in de openbare apotheek aan de orde. In hoeverre worden er afspraken met medewerkers over het volgen van cursussen gemaakt en worden er meer cursussen gevolgd wanneer er een duidelijk HRM-beleid op dit terrein is?

\subsection{Participatie in cursussen}

In de openbare apotheek volgen veel medewerkers cursussen. Neemt in de gehele zorgsector $53 \%$ van de medewerkers in twee jaar tijd aan één of meerdere cursussen deel ${ }^{28}$, tabel 5.1 laat zien dat dit percentage voor apothekersassistenten in het jaar 2003 alleen al maar liefst $75 \%$ bedraagt. Dit is beduidend meer dan in 2001, toen nog $64 \%$ van de assistenten cursussen volgde. ${ }^{29}$ Assistenten die in een van de drie variant-functies werkzaam zijn, nemen nog vaker aan een cursus deel. Zo heeft maar liefst $88 \%$ van de apothekersassistenten in de variant kwaliteitszorg in 2003 één of meerdere cursussen gevolgd.

Tabel 5.1

Deelname aan cursussen in 2003

$\begin{array}{lr} & \text { Deelname aan cursussen } \\ \%\end{array}$

. niet berekend

Bron: ROA

De cursusparticipatie van de overige apotheekmedewerkers ligt wat lager. Bijna een kwart van de apotheekhulpen heeft een cursus gevolgd, terwijl $31 \%$ van het admini-

28. Het betreft hier de periode januari 2001 tot januari 2003, zie: S. Bekker, G. van Essen, E. Josten en H. Meihuizen (2003). Arbeid in zorg en welzijn. Integrerend OSA-rapport 2003. OSA-publicatie ZW47, Tilburg.

29. In paragraaf 5.2 zullen we zien dat de stijging van het percentage apothekersassistenten dat een cursus volgde slechts voor een klein deel verklaard kan worden door de afschaffing van het systeem van salarisverhoging via het deelnemen aan cursussen op 1 januari 2004. Immers, slechts 4\% van de assistenten heeft in 2003 een cursus gevolgd om de 120 studiepunten te behalen die nodig zijn voor een salarisverhoging. 
stratief en secretarieel personeel aan een cursus heeft deelgenomen. Bezorgers en schoonmakers volgen echter nauwelijks cursussen.

Tabel 5.2 toont aan dat schoolverlaters en herintreders in 2003 ongeveer evenveel aan cursussen deelnemen als andere apothekersassistenten. Dit is een opmerkelijk verschil met 2001, toen schoolverlaters juist vaker cursussen volgden en herintreders minder vaak. Blijkbaar wordt er nu door alle assistenten in de apotheek veel aan scholing gedaan. Dit blijkt ook uit het feit dat in 2003 veel meer parttimers aan cursussen hebben deelgenomen dan in 2001. Wel is het nog altijd zo dat assistenten die veel uren in de openbare apotheek werkzaam zijn, eerder cursussen volgen dan assistenten die minder uren werken. Over het algemeen wordt aangenomen dat scholing van parttimers een lager rendement heeft, omdat het langer duurt voordat de investeringen in cursussen terugverdiend zijn. lemands werkervaring speelt overigens ook een rol. Assistenten die meer dan 30 jaar werkervaring hebben, nemen het minst aan cursussen deel $(66 \%)$. Waarschijnlijk is het volgen van cursussen voor een deel van deze ervaren assistenten niet meer de inspanning waard, gezien het geringe aantal jaren dat zij nog in de apotheek zullen werken.

Tabel 5.2

Deelname aan cursussen in 2001 en 2003, naar kenmerken van apothekersassistenten, 2004

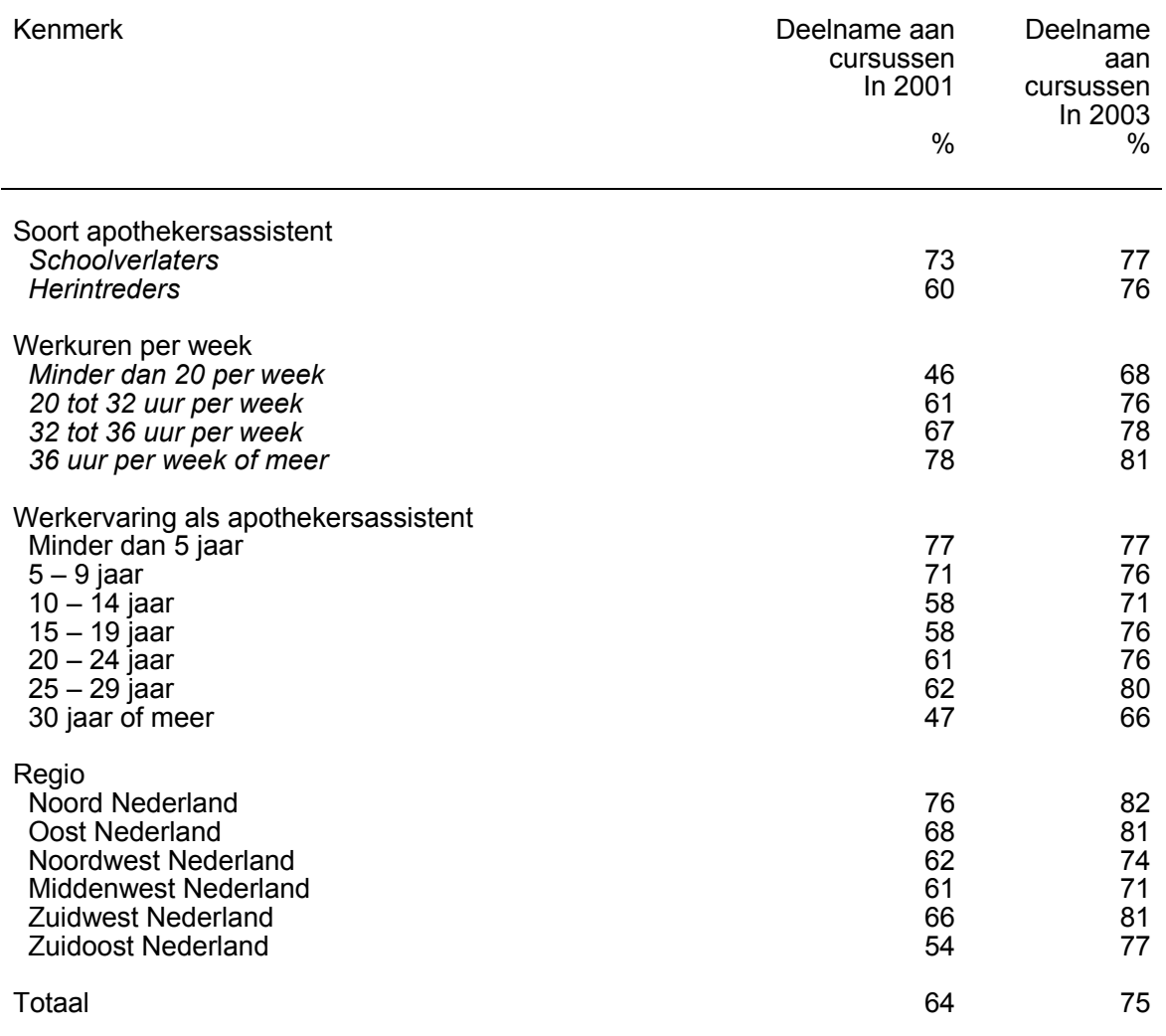

Bron: ROA 
Assistenten die werkzaam zijn in een zelfstandige apotheek nemen overigens even vaak aan cursussen deel als assistenten in een keten- of maatschapapotheek. Ook de grootte van de apotheek heeft geen invloed op de cursusparticipatie. Wel zijn er enkele regionale verschillen. Net als in 2001 worden er in Noord, Oost en Zuidwest Nederland vaker cursussen gevolgd dan in de Randstad (de regio's Noordwest en Middenwest Nederland). Opvallend is dat de cursusparticipatie in Zuidoost Nederland tussen 2001 en 2003 sterk gestegen is.

Welke cursussen worden er nu in 2003 door apotheekmedewerkers gevolgd? Tabel 5.3 laat zien dat apothekersassistenten met name scholing in vakkennis hebben gevolgd, zoals kennis van geneesmiddelen en zelfzorgartikelen $(67 \%)$ en kennis van ziektebeelden (56\%). Dit bleken ook in 2001 de meest populaire cursussen te zijn. Daarnaast volgde een kwart van de assistenten algemene cursussen op het gebied van deskundigheid en/of professionaliteit, en $21 \%$ cursussen in mondelinge en schriftelijke communicatie. Deze cursussen worden ook vaak gevolgd door de variant-apothekersassistenten. Deze assistenten namen daarnaast beduidend vaker aan cursussen op het terrein van de omgang en samenwerking met collega's deel dan de 'gewone' assistenten. Het is niet ondenkbaar dat de nieuwe variant-functies om een andere vorm van samenwerking met collega's vragen. Gespecialiseerde assistenten hebben immers een andere positie in het apotheekteam dan de overige assistenten. De variant-apothekersassistenten hebben wellicht op deze veranderingen ingespeeld door de genoemde cursussen te volgen. Verder zal het geen verbazing wekken dat assistenten in de variant coördinerend relatief vaak een cursus leidinggeven volgden, terwijl assistenten in de variant kwaliteitszorg vaak aan een cursus op het gebied van het realiseren, bewaken en bevorderen van het kwaliteitsbeleid deelnamen. Ook zijn er enkele regionale verschillen. In de regio Noordwest Nederland worden beduidend vaker cursussen leidinggeven gevolgd. Ook wordt hier meer aan ICT cursussen deelgenomen, terwijl deze cursussen in de regio Noord juist minder vaak gevolgd worden.

Net als de assistenten, volgden de apotheekhulpen in 2003 vaak scholing over kennis van geneesmiddelen en ziektebeelden en algemene cursussen over mondelinge en schriftelijke communicatie en deskundigheid en/of professionaliteit. Daarnaast namen deze ondersteunende apotheekmedewerkers veel vaker aan cursussen over vakvaardigheden deel dan de apothekersassistenten, en volgden ze vaak cursussen op een geheel ander gebied, zoals bedrijfshulpverlening (BHV). Voor de overige apotheekmedewerkers is het moeilijk een uitsplitsing van specifieke cursussen te geven, aangezien zij in veel kleinere aantallen aan cursussen deelnemen. Algemene cursussen op het gebied van mondelinge en schriftelijke communicatie lijken echter het meest populair te zijn. 


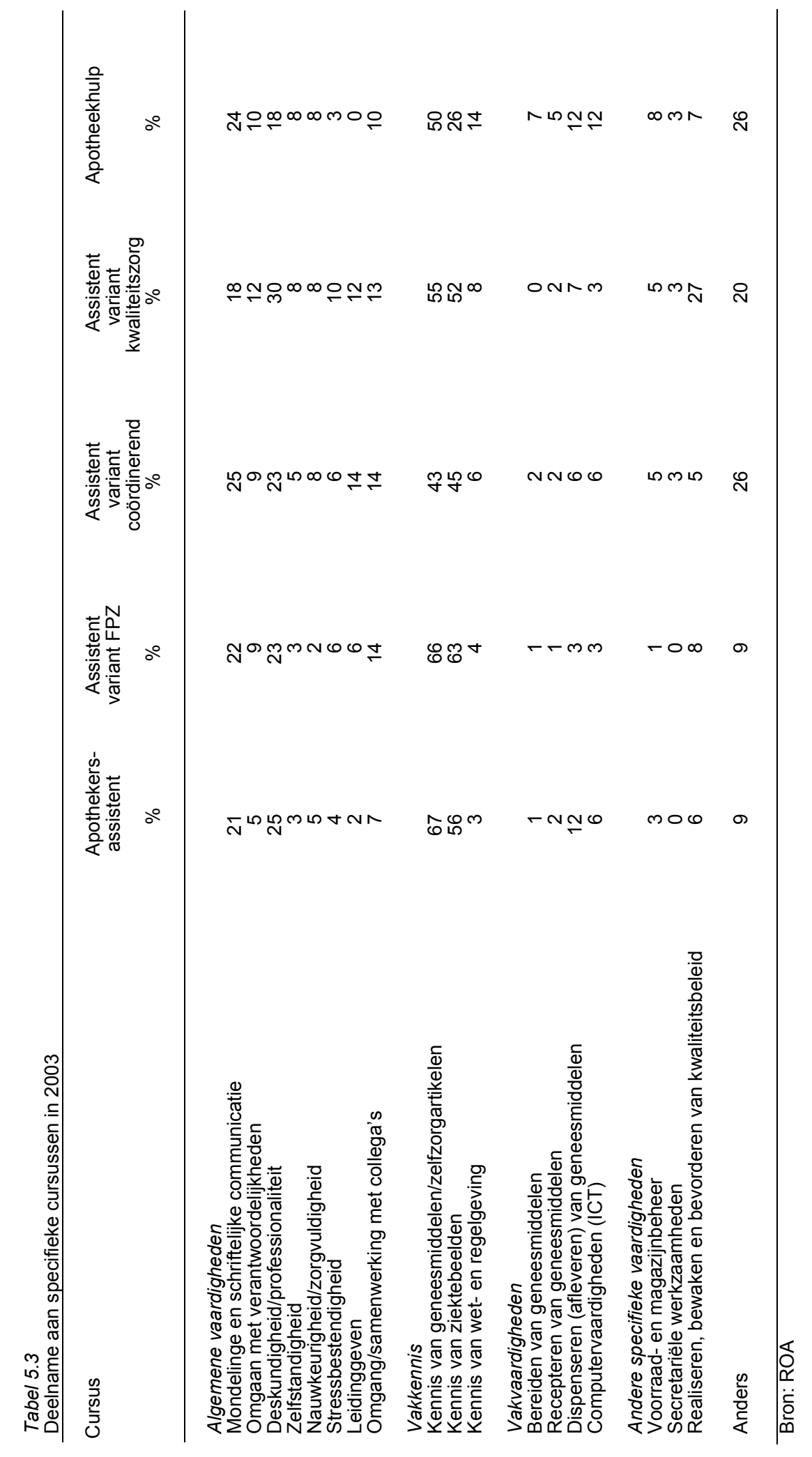


In welke vorm worden deze cursussen nu gevolgd? Tabel 5.4 geeft aan dat ruim een kwart van de apothekersassistenten samen met (een groot deel van) hun team aan een teamtraining heeft deelgenomen.

Tabel 5.4

Vorm waarin cursussen gevolgd worden in 2003

\begin{tabular}{lrrrrr}
\hline Vorm & $\begin{array}{r}\text { Apothekers } \\
\text { assistent }\end{array}$ & $\begin{array}{r}\text { Assistent } \\
\text { variant } \\
\text { FPZ }\end{array}$ & $\begin{array}{r}\text { Assistent } \\
\text { variant } \\
\text { coördinerend }\end{array}$ & $\begin{array}{r}\text { Assistent } \\
\text { variant } \\
\text { kwaliteits- } \\
\text { zorg } \\
\%\end{array}$ & $\begin{array}{r}\text { Apotheek } \\
\text { hulp }\end{array}$ \\
& $\%$ & $\%$ & $\%$ & & $\%$ \\
\hline Teamtrainingen & & & & & \\
Cursus op locatie & 34 & 39 & 73 & 44 & 9 \\
Cursus op de werkplek & 80 & 85 & 15 & 22 & 22 \\
E-learning & 16 & 14 & 6 & 7 & 4 \\
Zelfstudie & 6 & 11 & 15 & 14 & 20 \\
Anders & 15 & 8 & 2 & 2 & 0 \\
& 1 & 1 & & & \\
\end{tabular}

Bron: ROA

De meeste assistenten (80\%) volgen echter cursussen op locatie, buiten de werkplek. Vooral cursussen in leidinggeven en het bereiden van medicijnen worden op locatie gegeven. Dit is opmerkelijk, aangezien we in hoofdstuk 4 zagen dat meer dan $60 \%$ van de apothekersassistenten vindt dat het bereiden van medicijnen het best op de werkplek aangeleerd kan worden. Ongeveer $15 \%$ van de assistenten participeert in cursussen die op de werkplek plaatsvinden. Dit zijn vooral algemene cursussen als mondelinge en schriftelijke communicatie, stressbestendigheid en omgang en samenwerking met collega's. Met name apothekersassistenten in de variant kwaliteitszorg en apotheekhulpen nemen vaak deel aan een cursus op de werkplek. Verder doet één op de vijf apotheekhulpen aan zelfstudie. Deze vorm van scholing wordt wel toegepast bij het leren van vakkennis als kennis van geneesmiddelen en ziektebeelden. Uit hoofdstuk 4 bleek ook dat de apothekersassistenten vakkennis het meest geschikt vinden om via zelfstudie op peil te houden. E-learning, dat voornamelijk gebruikt wordt voor computercursussen, vindt nog niet veel plaats. Ten slotte participeert 1 à $2 \%$ van de medewerkers op een andere wijze in cursussen; het gaat dan vooral om cursussen via de telefoon.

Tabel 5.5 laat zien dat het initiatief voor het volgen van cursussen door meer dan de helft van de assistenten zelf genomen wordt. Met name bij cursussen over kennis van ziektebeelden of wet- en regelgeving en het bereiden van medicijnen, wordt het initiatief vaak door de apothekersassistenten zelf genomen. Ongeveer drie op de tien assistenten neemt samen met de apotheker het initiatief om aan een cursus deel te nemen. Hierbij gaat het vooral om cursussen ICT en secretariële werkzaamheden. De werkgever neemt ten slotte bij ongeveer $15 \%$ van de assistenten het initiatief tot het volgen van cursussen, met name voor cursussen mondelinge en schriftelijke communicatie en omgang en samenwerking met collega's. Dit laatste is niet zo verwonderlijk, aangezien uit hoofdstuk 4 al bleek dat de apothekers deze algemene competenties van apothekersassistenten lager inschatten dan de assistenten zelf. 
Tabel 5.5

Initiatief voor cursussen gevolgd in 2003

\begin{tabular}{lrrrrr}
\hline Initiatief & $\begin{array}{r}\text { Apothekers } \\
\text { assistent }\end{array}$ & $\begin{array}{r}\text { Assistent } \\
\text { variant } \\
\text { FPZ } \\
\%\end{array}$ & $\begin{array}{r}\text { Assistent } \\
\text { variant } \\
\text { coördinerend } \\
\%\end{array}$ & $\begin{array}{r}\text { Assistent } \\
\text { variant } \\
\text { kwaliteitszorg } \\
\%\end{array}$ & $\begin{array}{r}\text { Apotheek } \\
\text { hulp }\end{array}$ \\
\hline $\begin{array}{l}\text { Bij werkgever } \\
\text { Bij werknemer }\end{array}$ & 17 & 14 & 15 & 13 & 26 \\
Bij beiden & 54 & 58 & 52 & 55 & 31 \\
& 29 & 28 & 32 & 32 & 43
\end{tabular}

Bron: ROA

Voor apotheekhulpen liggen de cijfers wat anders: zij nemen veel minder vaak zelf het initiatief om een cursus te volgen. Vaak wordt door de ondersteunende medewerker en de apotheker samen besloten dat aan een cursus wordt deelgenomen, terwijl bij iets meer dan een kwart van de apotheekhulpen de apotheker het initiatief neemt tot het volgen van een cursus.

Net als in 2001 worden bijna alle cursussen wel door de werkgever betaald (zie tabel 5.6). Opvallend is hierbij dat assistenten in de variant kwaliteitszorg vaker zelf voor de kosten van een cursus opdraaien dan de andere assistenten. Dit geldt ook voor de apotheekhulpen: hier betaalt $11 \%$ de cursus zelf. Slechts in enkele gevallen ( 3 tot $6 \%$ van de apotheekmedewerkers) wordt de cursus niet door de apotheker of de apotheekmedewerker betaald, maar op een andere manier, bijvoorbeeld door de farmaceutische industrie.

Tabel 5.6

Betaling van cursussen gevolgd in 2003

\begin{tabular}{|c|c|c|c|c|c|}
\hline Betaling & $\begin{array}{r}\text { Apothekers } \\
\text { assistent } \\
\%\end{array}$ & $\begin{array}{r}\text { Assistent } \\
\text { variant } \\
\text { FPZ } \\
\%\end{array}$ & $\begin{array}{r}\text { Assistent } \\
\text { variant } \\
\text { coördinerend } \\
\%\end{array}$ & $\begin{array}{r}\text { Assistent } \\
\text { variant } \\
\text { kwaliteitszorg } \\
\%\end{array}$ & $\begin{array}{r}\begin{array}{r}\text { Apotheek } \\
\text { hulp } \\
\%\end{array} \\
\text { \% }\end{array}$ \\
\hline $\begin{array}{l}\text { Door werkgever } \\
\text { Door werknemer } \\
\text { Door beiden } \\
\text { Anders }\end{array}$ & $\begin{array}{r}95 \\
1 \\
2 \\
3\end{array}$ & $\begin{array}{r}92 \\
1 \\
2 \\
4\end{array}$ & $\begin{array}{r}95 \\
3 \\
2 \\
4\end{array}$ & $\begin{array}{r}87 \\
8 \\
4 \\
2\end{array}$ & $\begin{array}{r}81 \\
11 \\
3 \\
6\end{array}$ \\
\hline
\end{tabular}

Bron: ROA

Tabel 5.7 laat zien dat 45\% van de 'gewone' apothekersassistenten de cursussen in de eigen (vrije) tijd volgt. Ongeveer net zoveel assistenten nemen in werktijd aan cursussen deel, of krijgen voor hun studietijd betaald. Assistenten in de variant FPZ nemen vaker in hun eigen tijd aan cursussen deel, terwijl assistenten in de variant kwaliteitszorg juist vaker cursussen in werktijd volgen. Ook apotheekhulpen volgen vaak cursussen in hun eigen tijd (53\%). Dit is opvallend, omdat het initiatief om aan een cursus deel te nemen toch vaak door de apotheker genomen wordt. $35 \%$ van de apotheekhulpen volgt een cursus geheel in werktijd. $\mathrm{Er}$ is overigens geen verband tussen het aantal uren dat assistenten of overige apotheekmedewerkers per week werken en het volgen van cursussen in werktijd of in de eigen (vrije) tijd. 
Tabel 5.7

Tijd waarin cursussen gevolgd worden in 2003

\begin{tabular}{|c|c|c|c|c|c|}
\hline Tijd & $\begin{array}{r}\text { Apothekers } \\
\text { assistent } \\
\%\end{array}$ & $\begin{array}{r}\text { Assistent } \\
\text { variant } \\
\text { FPZ } \\
\%\end{array}$ & $\begin{array}{r}\text { Assistent } \\
\text { variant } \\
\text { coördinerend } \\
\%\end{array}$ & $\begin{array}{r}\text { Assistent } \\
\text { variant } \\
\text { kwaliteitszorg } \\
\%\end{array}$ & $\begin{array}{r}\begin{array}{r}\text { Apotheek } \\
\text { hulp } \\
\%\end{array} \\
\%\end{array}$ \\
\hline $\begin{array}{l}\text { In werktijd } \\
\text { In eigen tijd / vrije tijd } \\
\text { Beide }\end{array}$ & $\begin{array}{l}44 \\
45 \\
11\end{array}$ & $\begin{array}{l}36 \\
50 \\
14\end{array}$ & $\begin{array}{l}48 \\
34 \\
19\end{array}$ & $\begin{array}{r}59 \\
34 \\
7\end{array}$ & $\begin{array}{l}35 \\
53 \\
13\end{array}$ \\
\hline
\end{tabular}

Bron: ROA

\subsection{Het nut van scholing}

Waarom volgen apotheekmedewerkers cursussen? Tabel 5.8 geeft aan dat er vooral aan scholing wordt deelgenomen om bij te blijven. Net als in 2001 geeft meer dan $40 \%$ van de assistenten aan dit de belangrijkste reden te vinden om cursussen te volgen. Het gaat dan met name om cursussen op het gebied van kennis van geneesmiddelen en ziektebeelden. Daarnaast wil ongeveer $15 \%$ van de assistenten door het volgen van cursussen een tekort aan vaardigheden - vaak betreft het computervaardigheden - wegwerken of zich verder specialiseren. De variant-apothekersassistenten volgen opvallend minder vaak een cursus om een tekort aan vaardigheden weg te werken, maar nemen wel vaker dan de 'gewone' assistenten aan een cursus deel om zich verder te specialiseren of om promotie te kunnen maken. Dit betekent dat de variant-assistenten duidelijk bezig zijn met hun carrière binnen de apotheek. Met name cursussen op het gebied van leidinggeven, omgaan met verantwoordelijkheden, zelfstandigheid en stressbestendigheid worden gevolgd om promotie te kunnen maken.

Tabel 5.8

Belangrijkste reden om cursussen te volgen, 2004

$\begin{array}{lrrrrr}\text { Reden } & \begin{array}{r}\text { Apothekers } \\ \text { assistent }\end{array} & \begin{array}{r}\text { Assistent } \\ \text { variant } \\ \text { FPZ } \\ \%\end{array} & \begin{array}{r}\text { Assistent } \\ \text { variant } \\ \text { coördinerend } \\ \%\end{array} & \begin{array}{r}\text { Assistent } \\ \text { variant }\end{array} & \begin{array}{r}\text { Apotheek } \\ \text { kwaliteitszorg } \\ \%\end{array} \\ \text { hulp } \\ \%\end{array}$

Bron: ROA

De ondersteunende apotheekmedewerkers volgen ook vaak cursussen om bij te blijven, maar geven daarnaast aan cursussen te volgen uit persoonlijke interesse. Ook geven apotheekhulpen wat vaker andere, uiteenlopende redenen aan waarom 
ze aan cursussen hebben deelgenomen, bijvoorbeeld ter voorbereiding op een project of als herhalingscursus die ieder jaar plaatsvindt.

Omdat op 1 januari 2004 het systeem van salarisverhoging door middel van het behalen van 120 studiepunten voor cursussen is vervallen ${ }^{30}$, volgen nog maar zeer weinig medewerkers om deze reden cursussen. In 2001 was dit nog voor $13 \%$ van de assistenten de belangrijkste reden om aan cursussen deel te nemen, nu heeft $4 \%$ van de assistenten een cursus gevolgd om de voor de salarisverhoging benodigde 120 studiepunten te halen.

Aangezien we over gegevens beschikken van twee cycli van de Arbeidsmarktmonitor Apotheekbranche, is het mogelijk om na te gaan of het volgen van een cursus ook echt geleid heeft tot een verbetering van de competenties van apothekersassistenten. Hiertoe hebben we de rapportcijfers van assistenten die aan beide onderzoeken hebben deelgenomen op een negental kerncompetenties ${ }^{31}$ vergeleken. Uit tabel 5.9 blijkt dat ongeveer de helft van de assistenten deze competenties in 2001 en 2004 met dezelfde score waarderen. Bij eenvijfde tot een kwart van de assistenten is het niveau in algemene competenties als mondelinge en schriftelijke communicatie, zelfstandigheid, omgaan met verantwoordelijkheden en omgang en samenwerking met collega's in deze periode echter gestegen. Voor de vakvaardigheden bereiden en recepteren van geneesmiddelen geldt dit voor meer dan een kwart van de assistenten. Daarnaast geeft 30\% van de assistenten zichzelf in 2004 een hoger rapportcijfer voor computervaardigheden dan in 2001, terwij dit voor de kennis van geneesmiddelen en zelfzorgartikelen en de kennis van ziektebeelden zelfs bij $37 \%$ van de assistenten het geval is.

Tabel 5.9

Verandering in het competentieniveau van apothekersassistenten tussen 2001 en 2004

\begin{tabular}{|c|c|c|c|}
\hline Competentie & $\begin{array}{r}\text { Verslechtering } \\
\%\end{array}$ & $\begin{array}{r}\text { Geen } \\
\text { verandering } \\
\%\end{array}$ & $\begin{array}{r}\text { Verbetering } \\
\%\end{array}$ \\
\hline \multicolumn{4}{|l|}{ Algemene vaardigheden } \\
\hline Mondelinge en schriftelijke communicatie & 28 & 52 & 19 \\
\hline Omgaan met verantwoordelijkheden & 29 & 51 & 20 \\
\hline Zelfstandigheid & 24 & 51 & 25 \\
\hline Omgang/samenwerking met collega's & 22 & 53 & 25 \\
\hline \multicolumn{4}{|l|}{ Vakkennis en -vaardigheden } \\
\hline Kennis van geneesmiddelen/zelfzorgartikelen & 11 & 52 & 37 \\
\hline Kennis van ziektebeelden & 16 & 47 & 37 \\
\hline Bereiden van geneesmiddelen & 27 & 47 & 26 \\
\hline Recepteren van geneesmiddelen & 21 & 53 & 27 \\
\hline Computervaardigheden & 24 & 47 & 30 \\
\hline
\end{tabular}

Bron: ROA

30. SBA (2002). CAO Apotheken 2002-2003. Nieuwegein.

31. Het gaat dan om de volgende competenties: mondelinge en schriftelijke communicatie, omgaan met verantwoordelijkheden, zelfstandigheid, omgang en samenwerking me collega's, kennis van geneesmiddelen en zelfzorgartikelen, kennis van ziektebeelden en computervaardigheden. 
Het volgen van een cursus in 2003 lijkt echter geen direct meetbare invloed te hebben gehad op het verbeteren van het niveau van deze kerncompetenties tussen 2001 en 2004. Dit was alleen het gevolg bij de assistenten die cursussen op het gebied van kennis van ziektebeelden volgden. Deze assistenten gaven zichzelf in 2004 een beduidend hoger rapportcijfer voor hun kennis van ziektebeelden dan in 2001. Dat er bij de andere kerncompetenties geen direct meetbaar effect van het volgen van een cursus gevonden wordt, betekent niet dat deze cursussen weinig nut hebben. De competenties van de assistenten zijn immer subjectief, dat wil zeggen door henzelf, beoordeeld. Wellicht stellen zij na het volgen van een cursus hogere eisen aan zichzelf, omdat ze dan meer oog krijgen voor de nog ontbrekende kennis en vaardigheden. Hierdoor zouden ze negatiever kunnen gaan denken over hun competenties, terwijl die objectief gezien wel verbeterd zijn.

Dat cursussen wel degelijk nuttig zijn blijkt ook uit tabel 5.10. De door de apotheekmedewerkers gevolgde cursussen komen immers over het algemeen goed van pas in het werk in de apotheek. De meeste medewerkers geven aan dat de opgedane kennis en vaardigheden door henzelf en/of door collega's gebruikt worden. Hierbij is het opvallend dat assistenten in 2003 vaker cursussen hebben gevolgd waarvan de opgedane kennis en vaardigheden zowel door henzelf als door collega's gebruikt worden (45\% tegenover $36 \%$ in 2001). Net als in 2001, vinden slechts zeer weinig apotheekmedewerkers dat de door hen gevolgde cursussen helemaal niet van pas komen in het werk omdat niemand in de openbare apotheek de opgedane kennis en vaardigheden gebruikt.

Tabel 5.10

Gebruik van opgedane kennis en vaardigheden van in 2003 gevolgde cursussen, 2004

\begin{tabular}{lrrrrr}
\hline Gebruik & $\begin{array}{r}\text { Apothekers } \\
\text { assistent }\end{array}$ & $\begin{array}{r}\text { Assistent } \\
\text { variant } \\
\text { FPZ } \\
\%\end{array}$ & $\begin{array}{r}\text { Assistent } \\
\text { variant } \\
\text { coördinerend } \\
\%\end{array}$ & $\begin{array}{r}\text { Assistent } \\
\text { variant } \\
\text { kwaliteitszorg } \\
\%\end{array}$ & $\begin{array}{r}\text { Apotheek } \\
\text { hulp }\end{array}$ \\
\hline Door medewerker zelf & 50 & 46 & 46 & 42 & 58 \\
Door collega's & 1 & 2 & 2 & 2 & 3 \\
Door beiden & 45 & 48 & 48 & 53 & 33 \\
Geen gebruik & 4 & 3 & 5 & 3 & 6
\end{tabular}

Bron: ROA

\subsection{Behoefte aan verdere scholing}

Tabel 5.11 laat zien dat er een grote behoefte is aan verdere bij- of nascholing in de openbare apotheek. 95\% van de apothekersassistenten wil graag in de toekomst één of meerdere cursussen volgen. Ook het merendeel van de apotheekhulpen (84\%) heeft behoefte aan verdere bij- of nascholing. Van de administratief en secretarieel medewerkers wil $65 \%$ een cursus volgen, terwijl bezorgers en schoonmakers met respectievelijk $32 \%$ en $24 \%$ de minste behoefte aan bij- of nascholing hebben. Eerder in dit hoofdstuk zagen we al dat deze overige apotheekmedewerkers beduidend minder cursussen volgen dan de apothekersassistenten. Het is verder opvallend dat slechts een kwart van de apotheekhulpen in 2003 een cursus gevolgd heeft, terwijl maar liefst $84 \%$ aangeeft behoefte aan bij- of nascholing te hebben. $\mathrm{Er}$ 
zou dus meer aandacht kunnen uitgaan naar de cursusparticipatie van algemeen ondersteunende medewerkers in de openbare apotheek.

Tabel 5.11

Behoefte aan verdere bij- of nascholing, 2004

Behoefte aan bij- of nascholing

Apothekersassistent

Apothekersassistent variant FPZ

Apothekersassistent variant coördinerend

Apothekersassistent variant kwaliteitszorg

BBL'er

Apotheekhulp

Administratief en secretarieel medewerker

Bezorger

Schoonmaker

Bron: ROA

Tabel 5.12 geeft aan welke cursussen apothekersassistenten graag willen volgen. Het meest populair, zowel bij de 'gewone' assistenten als bij de variant-assistenten, zijn de cursussen over kennis van geneesmiddelen en kennis van ziektebeelden. Deze vakkennis-cursussen zijn in 2003 overigens ook het meest door assistenten gevolgd. Daarnaast is er een grote behoefte aan ICT-cursussen. 'Gewone' assistenten willen ook nog deelnemen aan cursussen op het gebied van kennis van weten regelgeving en het realiseren, bewaken en bevorderen van kwaliteitsbeleid. Apothekersassistenten in de variant FPZ hebben meer behoefte aan cursussen over leidinggeven en mondelinge en schriftelijke communicatie, terwijl assistenten in de variant coördinerend cursussen over leidinggeven en kennis van wet- en regelgeving willen volgen. Apothekersassistenten in de variant kwaliteitszorg ten slotte hebben vooral behoefte aan cursussen op het gebied van realiseren, bewaken en bevorderen van kwaliteitsbeleid en kennis van wet- en regelgeving.

Tabel 5.12

Top-vijf van cursussen waaraan apothekersassistenten de meeste behoefte hebben, 2004

\begin{tabular}{lrlr} 
& $\begin{array}{r}\text { Behoefte } \\
\%\end{array}$ & & $\begin{array}{r}\text { Behoefte } \\
\%\end{array}$ \\
\hline Apothekersassistent & & Assistent variant FPZ & \\
Kennis van ziektebeelden & 71 & Kennis van ziektebeelden & 69 \\
Kennis van geneesmiddelen & 65 & Kennis van geneesmiddelen & 51 \\
Computervaardigheden (ICT) & 45 & Computervaardigheden (ICT) & 50 \\
Kennis van wet- en regelgeving & 27 & Leidinggeven & 29 \\
Kwaliteitsbeleid & 22 & Communicatie & \\
Assistent variant coördinerend & & Assistent variant kwaliteitszorg & \\
Kennis van ziektebeelden & & Kennis van ziektebeelden & 65 \\
Kennis van geneesmiddelen & 59 & Kennis van geneesmiddelen & 50 \\
Leidinggeven & 45 & Kwaliteitsbeleid & 41 \\
Kennis van wet- en regelgeving & 41 & Computervaardigheden (ICT) & 40 \\
Computervaardigheden (ICT) & 40 & Kennis van wet- en regelgeving & 29
\end{tabular}

Bron: ROA 


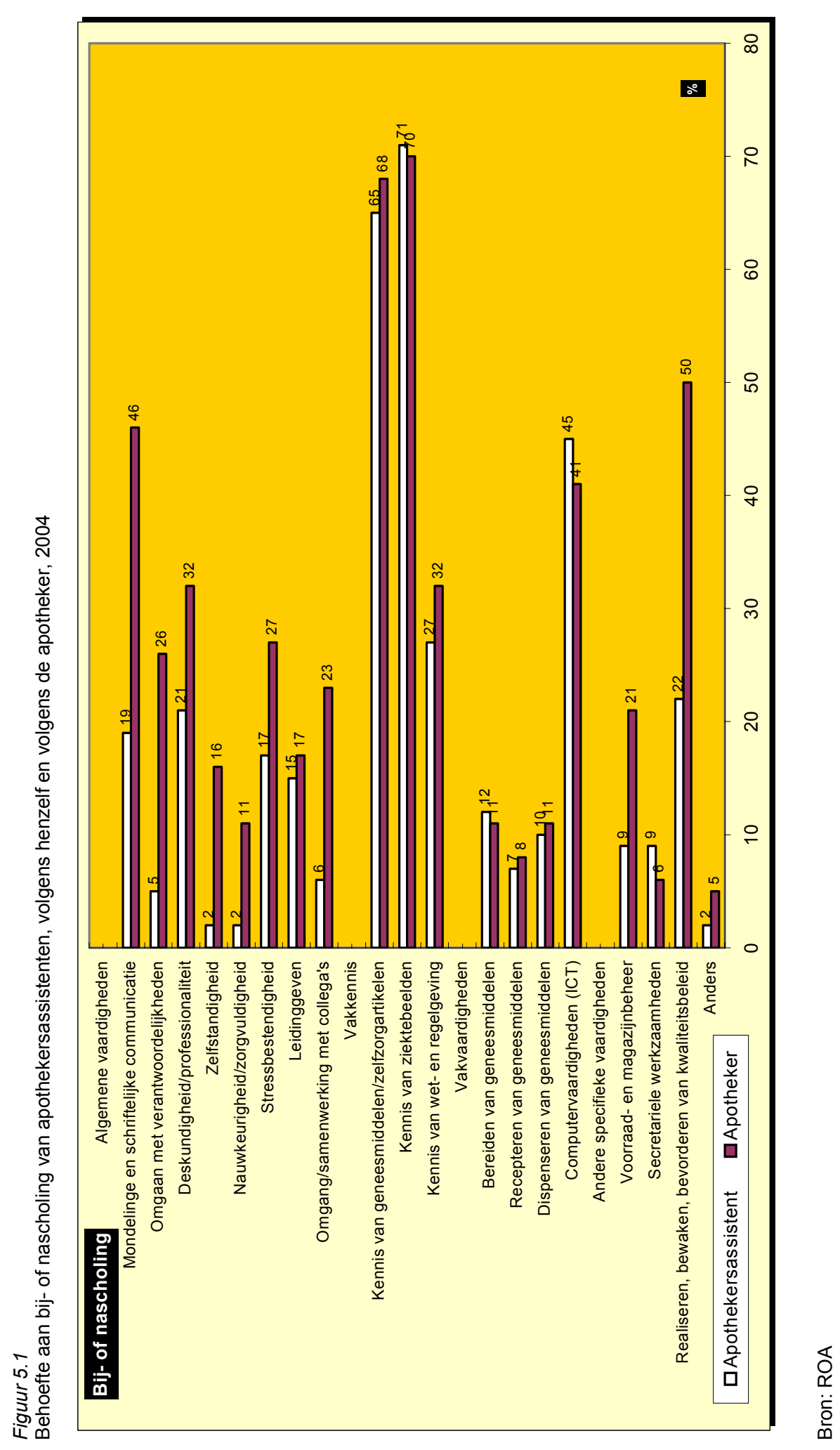


Uit figuur 5.1 blijkt dat ook de apothekers vinden dat de behoefte aan bij- of nascholing voor apothekersassistenten het grootst is op het gebied van kennis van geneesmiddelen en zelfzorgartikelen (70\%), kennis van ziektebeelden $(68 \%)$ en computervaardigheden (41\%). Opvallend is wel dat apothekers beduidend vaker dan apothekersassistenten zelf vinden dat assistenten cursussen in het realiseren, bewaken en bevorderen van kwaliteitsbeleid en voorraad- en magazijnbeheer zouden moeten volgen. Hetzelfde geldt voor cursussen in algemene vaardigheden, zoals mondelinge en schriftelijke communicatie, omgaan met verantwoordelijkheden en omgang en samenwerking met collega's.

Er bestaat overigens een duidelijk verband tussen de competenties van apothekersassistenten en de behoefte aan bij- of nascholing. Assistenten die lager scoren op een specifieke competentie, hebben meer behoefte aan een cursus op dat gebied dan assistenten die zichzelf een hoge score geven. Assistenten geven hiermee aan dat ze hun minder goed ontwikkelde kanten willen verbeteren door het volgen van een cursus. Overigens heeft het niveau van de competenties 'computervaardig heden' en 'kennis van wet- en regelgeving' geen invloed op de behoefte aan cursussen op deze twee gebieden. Zowel assistenten met een lage als met een hoge score voor deze competenties willen hier graag bij- of nascholing in volgen.

Tabel 5.13

Top-vijf van cursussen waaraan apotheekmedewerkers de meeste behoefte hebben, 2004

\begin{tabular}{lrlr} 
& $\begin{array}{r}\text { Behoefte } \\
\%\end{array}$ & $\begin{array}{r}\text { Behoefte } \\
\%\end{array}$ \\
\hline Apotheekhulp & & Administratief en secretarieel medew. \\
Kennis van geneesmiddelen & 40 & Computervaardigheden (ICT) & 31 \\
Computervaardigheden (ICT) & 37 & Secretariële werkzaamheden & 20 \\
Kennis van ziektebeelden & 25 & Communicatie & 16 \\
Kennis van wet- en regelgeving & 20 & Kennis van geneesmiddelen & 16 \\
Voorraad- en magazijnbeheer & 18 & Kennis van wet- en regelgeving & 15 \\
& & & \\
Bezorger & & Schoonmaker & \\
Kennis van geneesmiddelen & 14 & Computervaardigheden (ICT) & 10 \\
Computervaardigheden (ICT) & 12 & Communicatie & 4 \\
Stressbestendigheid & 8 & Deskundigheid/professionaliteit & 4 \\
Kennis van ziektebeelden & 7 & Voorraad- en magazijnbeheer \\
Voorraad- en magazijn beheer & 7 & Omgang/samenwerking met collega's & 3 \\
\hline Bron: ROA & & & \\
\hline
\end{tabular}

Bron: ROA

Tabel 5.13 geeft aan welke cursussen de overige apotheekmedewerkers willen volgen. Apotheekhulpen hebben vooral behoefte aan cursussen over kennis van geneesmiddelen en zelfzorgartikelen, computervaardigheden, kennis van ziektebeelden, kennis van wet- en regelgeving en voorraad- en magazijnbeheer. Gezien hun ondersteunende functie, zal het geen verbazing wekken dat de cursusbehoefte van apotheekhulpen overeenkomt met de behoefte van de apothekersassistenten, op de cursussen voorraad- en magazijnbeheer na. Apotheekhulpen die lager scoren op algemene vaardigheden zoals mondelinge en schriftelijke communicatie, zelfstandigheid en stressbestendigheid, hebben overigens meer behoefte aan cursussen op 
deze gebieden dan apotheekhulpen die zichzelf een hogere score voor deze competenties geven. Dit geldt echter niet voor de vakspecifieke vaardigheden als kennis van geneesmiddelen en ziektebeelden en het recepteren en bereiden van geneesmiddelen.

Ook de cursusbehoefte van de administratieve en secretariële medewerkers ligt in het verlengde van hun werkzaamheden. Zo geven zij aan cursussen te willen volgen in computervaardigheden en secretariële werkzaamheden. Daarnaast hebben zij behoefte aan bij- of nascholing in mondelinge en schriftelijke communicatie, kennis van geneesmiddelen en zelfzorgartikelen en kennis van wet- en regelgeving.

De behoefte van bezorgers en schoonmakers aan bij- of nascholing is veel kleiner. Eén op de zeven bezorgers zou graag cursussen volgen over kennis van geneesmiddelen. Daarnaast geven sommige bezorgers aan behoefte te hebben aan cursussen op het terrein van computervaardigheden, stressbestendigheid, kennis van ziektebeelden en voorraad- en magazijnbeheer. Een klein deel van de schoonmakers ten slotte ziet wel wat in cursussen computervaardigheden en mondelinge en schriftelijke communicatie.

Uit figuur 5.2 blijkt dat apothekers ook van mening zijn dat apotheekhulpen cursussen op het gebied van kennis van ziektebeelden, kennis van geneesmiddelen en zelfzorgartikelen en computervaardigheden zouden moeten volgen. Zij vinden dit zelfs vaker dan de apotheekhulpen zelf. Daar staat tegenover dat apothekers minder zien in het volgen van cursussen voorraad- en magazijnbeheer dan de apotheekhulpen

\subsection{HRM-beleid en scholing}

In hoeverre worden er in de openbare apotheek afspraken gemaakt over de persoonlijke ontwikkeling van medewerkers en het volgen van cursussen? Tabel 5.14 geeft aan dat met $26 \%$ van de apothekersassistenten dergelijke afspraken gemaakt zijn. Slechts $2 \%$ van hen heeft een persoonlijk ontwikkelingsplan (POP). Bij de variantapothekersassistenten liggen deze percentages iets hoger. Zo heeft $41 \%$ van de assistenten in de variant kwaliteitszorg afspraken gemaakt en heeft $7 \%$ een POP. Uit het werkgeversonderzoek bleek al dat apotheken die veel aan functiedifferentiatie doen, meer Human Resource Management (HRM) instrumenten inzetten dan apotheken met weinig functiedifferentiatie. Overigens blijkt dat nogal wat assistenten graag zouden willen dat er afspraken over hun persoonlijke ontwikkeling of de te volgen cursussen gemaakt worden. Ongeveer een kwart tot eenderde van de assistenten geeft immers aan dat hierover met hen geen afspraken gemaakt zijn, terwijl ze daar wel degelijk behoefte aan hebben. 


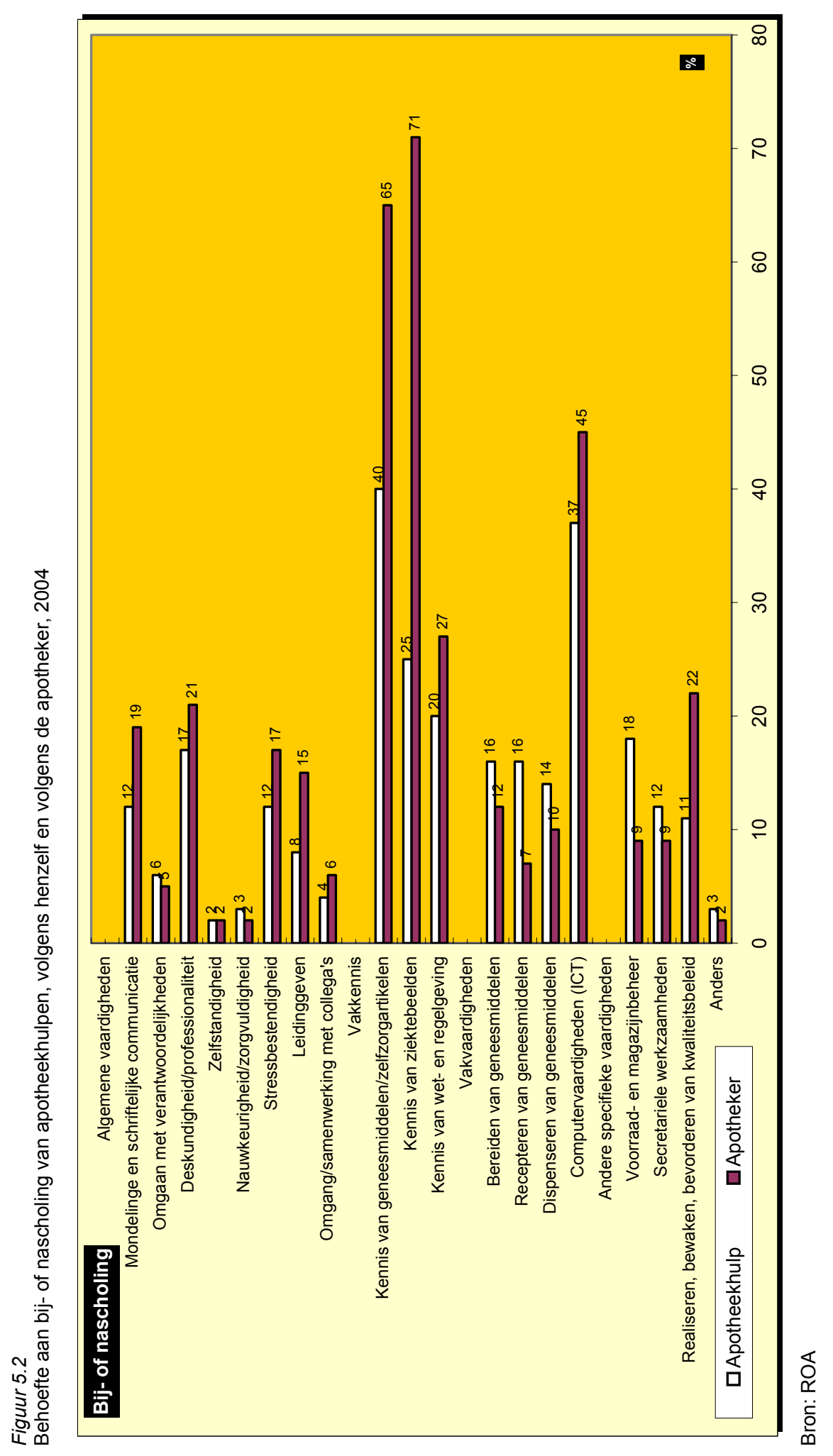


Tabel 5.14

Afspraken over persoonlijke ontwikkeling en cursussen, 2004

\begin{tabular}{|c|c|c|c|c|}
\hline & $\begin{array}{r}\text { Afspraken } \\
\text { gemaakt } \\
\%\end{array}$ & $\begin{array}{l}\text { POP } \\
\%\end{array}$ & $\begin{array}{r}\text { Nee, maar } \\
\text { wel behoefte } \\
\%\end{array}$ & $\begin{array}{r}\text { Nee, maar ook } \\
\text { geen behoefte } \\
\%\end{array}$ \\
\hline $\begin{array}{l}\text { Apothekersassistent } \\
\text { Assistent variant FPZ } \\
\text { Assistent variant coördinerend } \\
\text { Assistent variant kwaliteitszorg } \\
\text { BBL'er } \\
\text { Apotheekhulp } \\
\text { Administratief en secretarieel medew. } \\
\text { Bezorger } \\
\text { Schoonmaker }\end{array}$ & $\begin{array}{r}26 \\
35 \\
28 \\
41 \\
44 \\
15 \\
19 \\
4 \\
3\end{array}$ & $\begin{array}{r}2 \\
5 \\
3 \\
7 \\
11 \\
2 \\
2 \\
1 \\
1\end{array}$ & $\begin{array}{l}25 \\
28 \\
33 \\
28 \\
27 \\
31 \\
24 \\
12 \\
16\end{array}$ & $\begin{array}{l}46 \\
33 \\
36 \\
24 \\
19 \\
52 \\
55 \\
84 \\
80\end{array}$ \\
\hline
\end{tabular}

Bron: ROA

Ook met de BBL'ers zijn vaak afspraken gemaakt over hun persoonlijke ontwikkeling en de te volgen cursussen (44\%). Met de overige apotheekmedewerkers zijn daarentegen veel minder vaak afspraken op dit punt gemaakt. Een deel van deze medewerkers, met name de apotheekhulpen, heeft hier echter wel behoefte aan. De meeste bezorgers en schoonmakers vinden het daarentegen prima dat er geen afspraken met hen gemaakt zijn.

\section{Figuur 5.3}

Tevredenheid van apothekersassistenten met de gemaakte afspraken over persoonlijke ontwikkeling en cursussen, 2004

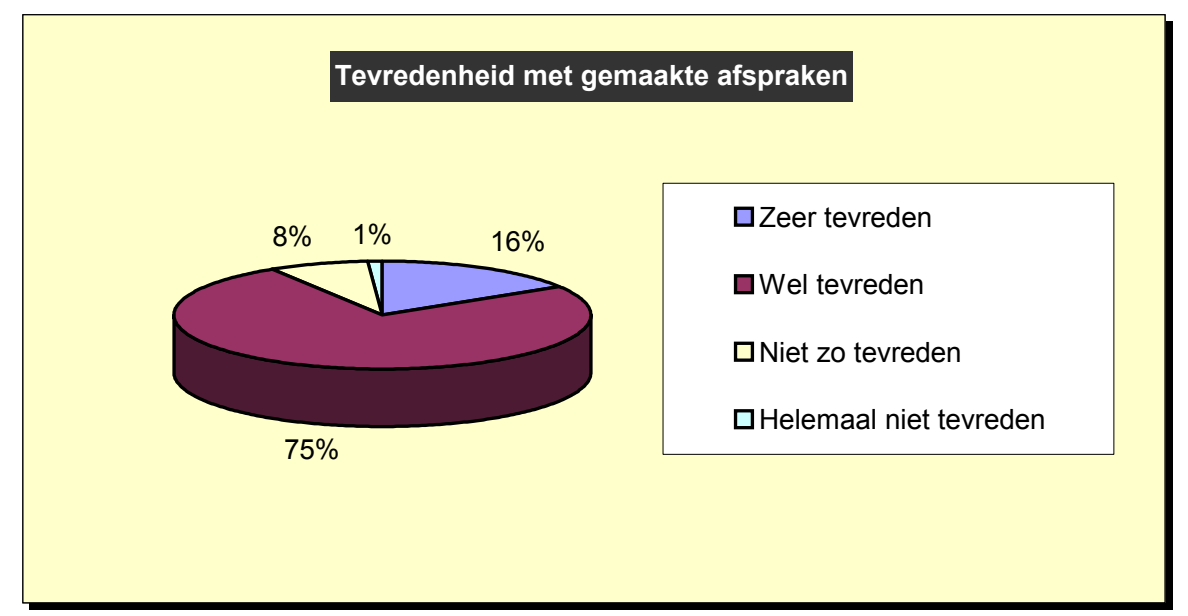

Bron: ROA

Van de assistenten die afspraken over hun persoonlijke ontwikkeling en de te volgen cursussen gemaakt hebben, is de overgrote meerderheid (zeer) tevreden, zo blijkt uit figuur 5.3. Slechts $9 \%$ is niet tevreden. Daarnaast geeft figuur 5.4 aan dat de weinige apothekersassistenten die een persoonlijk ontwikkelingsplan (POP) hebben, hier ook (zeer) tevreden over zijn. Er zijn op deze punten geen grote verschillen in de mate van tevredenheid tussen 'gewone' assistenten en variant-apothekersassistenten. 
Ook bij de overige apotheekmedewerkers overheerst een tevreden stemming, al is het hier moeilijk om een gedetailleerde uitsplitsing van cijfers te geven vanwege de kleine aantallen medewerkers waarmee daadwerkelijk afspraken gemaakt zijn.

Figuur 5.4

Tevredenheid van apothekersassistenten met het persoonlijk ontwikkelingsplan (POP), 2004

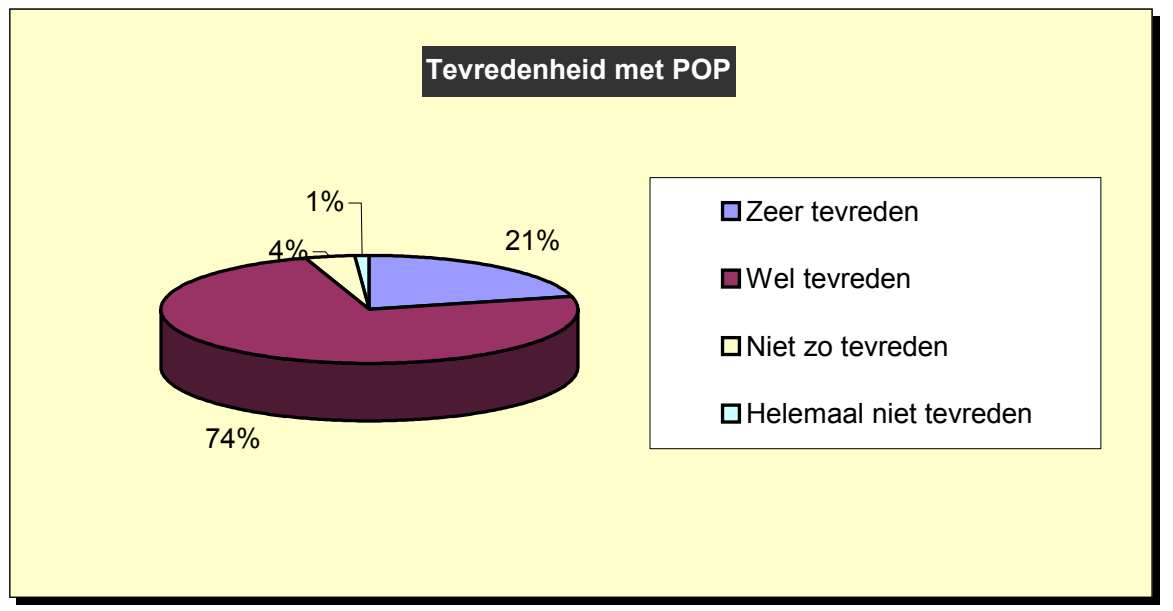

Bron: ROA

Tabel 5.15 laat zien dat apothekersassistenten meer cursussen volgen wanneer er met hen afspraken over persoonlijke ontwikkeling gemaakt zijn. 83\% van de assistenten waarmee afspraken gemaakt zijn, heeft in 2003 één of meerdere cursussen gevolgd, terwijl voor de assistenten met een POP dit percentage $80 \%$ is. Assistenten die geen afspraken gemaakt hebben, volgden beduidend minder vaak cursussen. Ook de deelname aan teamtrainingen ligt aanmerkelijk hoger voor assistenten die afspraken of een POP hebben. Deze verbanden gelden overigens zowel voor de 'gewone' apothekersassistenten als voor de variant-assistenten en blijven overeind staan wanneer er rekening gehouden wordt met een aantal belangrijke achtergrondkenmerken van assistenten en de apotheken waar ze werkzaam zijn. ${ }^{32}$

Tabel 5.15

Gemaakte afspraken over persoonlijke ontwikkeling en cursussen en deelname aan cursussen en teamtrainingen door apothekersassistenten, 2004

\begin{tabular}{lrr}
\hline & $\begin{array}{r}\text { Deelname aan } \\
\text { cursussen } \\
\%\end{array}$ & $\begin{array}{r}\text { Deelname aan } \\
\text { teamtrainingen } \\
\%\end{array}$ \\
\hline Afspraken gemaakt & 83 & 46 \\
Persoonlijk ontwikkelingsplan (POP) & 80 & 43 \\
Geen afspraken maar wel behoefte & 76 & 28 \\
Geen afspraken maar ook geen behoefte & 70 & 30 \\
\hline
\end{tabular}

Bron: ROA

32. Het gaat dan om kenmerken als werkervaring, aantal werkuren per week, soort apotheek, grootte van de apotheek en regio waarin men werkzaam is. 
Bijlage A en B 


\section{Bijlage A Vragenlijst apothekersassistenten}

\section{ARBEIDSMARKTMONITOR APOTHEKEN} APOTHEKERSASSISTENTEN 2004

\section{Internet?}

U kunt de vragenlijst ook via internet invullen!

Hoe gaat dat in zijn werk?

1. Bezoek: www.sbaweb.nl

2. klik op 'vragenlijst'. Dit is te vinden op de homepage onder de kop "NIEUW OP DE SITE".

3. Voer het volgende unieke wachtwoord in:

4. Als u via internet de vragenlijst invult, dan kunt $u$ deze vragenlijst weggooien. 


\section{Blok 1 Opleiding en werkervaring}

In dit eerste vragenblok willen we u een aantal vragen stellen over de opleiding(en) die u gevolgd heeft en uw werkervaring.

1. In welk jaar heeft u uw opleiding tot apothekersassistent afgerond?

012L4

2. Hoe beoordeelt u de aansluiting tussen de door u gevolgde opleiding tot apothekersassistent en uw huidige werk in de openbare apotheek?
$\square \quad$ Uitstekend
$\square$ Goed
$\square \quad$ Voldoende
$\square \quad$ Matig

$5 \square$ Slecht

016L1

3. Hoeveel jaar heeft $\mathrm{u}$ in totaal gewerkt als apothekersassistent?

$$
\text { jaar }
$$

4. En hoeveel jaar werkervaring heeft $u$ in totaal (dwz als apothekersassistent én in eventuele andere banen)?

Tel alle jaren dat $u$ betaalde arbeid verrichtte, in welke functie dan ook, mee.

Laat buiten beschouwing of $u$ al dan niet in deeltijd werkte.

$$
\text { jaar }
$$

\section{Blok 2 Huidige werksituatie}

De volgende vragen gaan over uw huidige werksituatie.

Wanneer $u$ in meerdere openbare apotheken werkt, ga dan uit van de werksituatie in de openbare apotheek waar $u$ de meeste uren werkt.

$5 \quad$ Sinds wanneer werkt $u$ in deze apotheek?

(Vul het jaar van indiensttreding in)

6a. Bent u de afgelopen jaren heringetreden als apothekersassistent?

$1 \square \mathrm{Ja}$, in het jaar

$2 \square \mathrm{Nee}$

-> ga verder met vraag 7 
6b. Hoeveel jaar heeft u uw loopbaan onderbroken? (Hoeveel jaar bent u er in totaal 'tussenuit' geweest?)

7. Wat is uw functie volgens het nieuwe functiewaarderingssysteem?

$1 \square$ Apothekersassistent 032L1

$2 \square$ Apothekersassistent variant FPZ 033L2

$3 \square$ Apothekersassistent variant coördinerend

$4 \square$ Apothekersassistent variant kwaliteitszorg

$5 \quad \square \quad$ Anders, namelijk:

8. Bent $u$ tevreden met de indeling van uw functie in het nieuwe functie waarderingssysteem?

$1 \square$ Zeer tevreden

$2 \square$ Tevreden

$3 \square \quad$ Niet zo tevreden

$4 \quad \square$ Helemaal niet tevreden

9. Heeft u een vast of een tijdelijk contract, of werkt $u$ via een uitzendbureau of op oproepbasis?

$1 \square$ Vast contract

$2 \square$ Tijdelijk contract met uitzicht op een vast contract

$\square \quad$ Tijdelijk contract zonder uitzicht op een vast contract

$\square$ Uitzendcontract

$5 \square$ Contract op oproepbasis

10. Hoeveel uur werkt u feitelijk gemiddeld per week? uur per week

11. En hoeveel uur zou u het liefst willen werken? uurperweek

12. Welke diensten draait $\mathbf{u}$ in de apotheek? (Meerdere antwoorden mogelijk)
$1 \square$ Dagdiensten
$1 \square$ Avonddiensten
$1 \square$ Nachtdiensten
$1 \square$ Zondagsdiensten
$1 \square$ Aanwezigheidsdiensten
$1 \square$ Bereikbaarheidsdiensten

13. Werkt u volgens een vast of wisselend rooster?

$\begin{array}{lll}1 & \square & \text { Vast rooster } \\ 2 & \square & \text { Wisselend rooster }\end{array}$ 


\section{Blok 3 Arbeidsomstandigheden}

14. Hoe ervaart u de werkdruk in uw werk?

(Geef uw mening aan door een kruisje te zetten)

Geen werkdruk

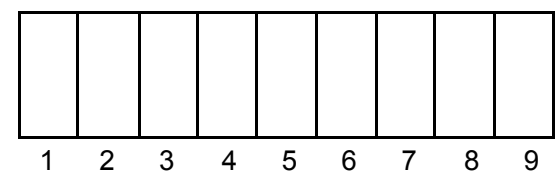

Extreem hoge

Werkdruk 051L2

15. Kunt u voor uw werk aangegeven of u altijd, vaak, soms, of nooit te maken hebt met de volgende aspecten?

Hoge tijdsdruk

Lichamelijk zwaar werk

Geestelijk zwaar werk

Fysieke omstandigheden als lawaai, tocht,

hoge of lage temperaturen, stof, etc.

Contact met gevaarlijke stoffen

Eentonig werk

Agressie/geweld

Pestgedrag
Altijd Vaak Soms Nooit

$1 \square \quad 2 \square \quad 3 \square \quad 4 \square$

$1 \square \quad 2 \square \quad 3 \square \quad 4 \square$

$1 \square \quad 2 \square \quad 3 \square \quad 4 \square$

$1 \square \quad 2 \square \quad 3 \square \quad 4 \square$

$1 \square \quad 2 \square \quad 3 \square \quad 4 \square$

$1 \square \quad 2 \square \quad 3 \square \quad 4 \square$

$1 \square \quad 2 \square \quad 3 \square \quad 4 \square$

$1 \square \quad 2 \square \quad 3 \square \quad 4 \square$

16a. Hoe vaak heeft u zich in de afgelopen 12 maanden ziek gemeld?

(Indien u zich 0 keer ziek heeft gemeld, ga dan verder met vraag 17)

\section{6b. Hoeveel dagen heeft $u$ de afgelopen 12 maanden van uw werk verzuimd} wegens ziekte?

(Tel zwangerschapsverlof niet mee)

$$
\text { dagen }
$$

(Indien u 0 dagen hebt verzuimd, ga dan verder met vraag 17)

16c. Lag de oorzaak van het laatste of eventueel uw huidige ziekteverzuim bij het werk of de werksituatie? (Meerdere antwoorden mogelijk)

$1 \square$ Nee, oorzaak had niet met het werk te maken

066L4+1

$1 \square$ Ja, oorzaak lag bij de hoge werkdruk

$1 \square$ Ja, oorzaak lag bij de zware lichamelijke belasting van het werk

7-12-2004/11317/Vr.lijst Apothekersassistenten 4 
$1 \square$ Ja, oorzaak lag bij een ander aspect van het werk

\section{Blok 4 Taken en werkzaamheden}

\section{Hoeveel procent van uw werktijd besteedt $u$ aan onderstaande}

werkzaamheden?

(In totaal moeten uw antwoorden optellen tot $100 \%$ )

$\%$

Recepten aanschrijven (ontvangen en $\quad$......

registreren) $\quad \ldots . .$.

$\begin{aligned} & \text { Recepten uitvullen (pakken en stickers } \\ & \text { plakken) }\end{aligned}$
Recepten aflev.

Recepten afleveren (plus standaard

voorlichting)

Bewaken van medicatie

Bereiden van geneesmiddelen

Bewaken van de voorraad

Farmaceutische patiëntenzorg (speciale of

bijzondere voorlichting)

Realiseren, bewaken en bevorderen van

kwaliteitsbeleid

Leidinggeven

Begeleiden van assistenten in opleiding

Administratie

Financiën (declaratieverkeer naar

verzekeraars, loonadministratie etc.)

Bezorgen van geneesmiddelen

Schoonmaken en huishoudelijke taken

Overige taken

Totaal

\section{8a. Bereidt u zelf medicijnen in de apotheek?}

$1 \square \mathrm{Ja}$

$2 \square \quad$ Nee

18b. Om welke bereidingen gaat het dan? (Meerdere antwoorden mogelijk)

$1 \square$ Gestandaardiseerde bereidingen

117L4+1

$1 \square$ Niet-gestandaardiseerde bereidingen

$1 \square$ Steriele bereidingen

$1 \square$ Bereidingen met risicovolle stoffen 
19. Verricht $u$ in uw huidige baan weleens werkzaamheden die strikt genomen niet bij uw functie horen?

(Meerdere antwoorden mogelijk)

$1 \quad \square \mathrm{Ja}$, taken uit hogere functies

$1 \quad \mathrm{Ja}$, taken uit lagere functies

$1 \square$ Nee

20a. Welke werkzaamheden worden weleens door apotheekhulpen van u overgenomen?

$1 \square$ geen apotheekhulp aanwezig $\quad$-> ga naar vraag $20 b$

\begin{abstract}
20b. En welke werkzaamheden zou u graag meer dan nu het geval is aan apotheekhulpen overlaten?

(Meerdere antwoorden mogelijk; deze vraag ook invullen indien er geen apotheekhulpen in de apotheek aanwezig zijn)
\end{abstract}

Werkzaamheden

Geen van mijn werkzaamheden

Recepten aanschrijven (ontvangen en registreren)

Recepten uitvullen (pakken en stickers plakken)

Recepten afleveren (plus standaard voorlichting)

Bewaken van medicatie

Bereiden van geneesmiddelen

Bewaken van de voorraad

Farmaceutische patiëntenzorg

(speciale of bijzondere voorlichting)

Realiseren, bewaken en bevorderen van

kwaliteitsbeleid

Leidinggeven

Begeleiden van assistenten in opleiding

Administratie

Financiën

(declaratieverkeer naar verzekeraars,

loonadministratie etc.)

Bezorgen van geneesmiddelen

Schoonmaken en huishoudelijke taken

Overige taken, namelijk:

7-12-2004/11317/Vr.lijst Apothekersassistenten 6

\begin{tabular}{ll}
\multicolumn{1}{c}{$20 \mathrm{a}$} & \multicolumn{1}{c}{$20 \mathrm{~b}$} \\
\hline Worden & Zouden meer \\
weleens door & dan nu het geval is \\
apotheekhulpen & $\begin{array}{l}\text { door apotheekhulpen } \\
\text { overgenomen }\end{array}$ \\
& $\begin{array}{l}\text { woeten } \\
\text { worden overgenomen }\end{array}$
\end{tabular}

$\begin{array}{lll}1 \square & 1 \square & \text { 127L16+1 } \\ 1 \square & 1 \square & \text { 144L16+1 } \\ 1 \square & 1 \square & \text { 161L2 } \\ 1 \square & 1 \square & 163 \mathrm{~L} 2 \\ 1 \square & 1 \square & \\ 1 \square & 1 \square & \\ 1 \square & 1 \square & \\ 1 \square & 1 \square & \end{array}$

$\begin{array}{ll}1 \square & 1 \square \\ 1 \square & 1 \square \\ 1 \square & 1 \square \\ 1 \square & 1 \square \\ 1 \square & 1 \square \\ 1 \square & 1 \square \\ 1 \square & 1 \square \\ 1 \square & 1 \square\end{array}$


21. Hoeveel uur per week verricht de apotheker in uw apotheek zelf taken die normaal gesproken tot het takenpakket van de apothekersassistenten worden gerekend?

\section{Blok 5 Cursussen en vaardigheden}

22. Heeft u de afgelopen 12 maanden één of meerdere aan uw werk gerelateerde cursussen gevolgd?

$1 \quad \square$ Ja

$2 \square \mathrm{Nee}$ -> ga verder met vraag 31

23. Heeft u samen met (een groot deel van) uw team aan teamtrainingen deel genomen?

$1 \square \mathrm{Ja}$

$2 \square \mathrm{Nee}$

24. De volgende vragen gaan over de laatste cursus die u gevolgd heeft. Op welke terreinen lag deze cursus? (Meerdere antwoorden mogelijk)

Algemene vaardigheden

$1 \square$ Mondelinge en schriftelijke communicatie

$1 \square$ Omgaan met verantwoordelijkheden

$1 \square$ Deskundigheid/ professionaliteit

$1 \quad$ Zelfstandigheid

$1 \square$ Nauwkeurigheid/ zorgvuldigheid

$1 \square$ Stressbestendigheid

$1 \square \quad$ Leidinggeven

$1 \square$ Omgang/samenwerking met collega's

\section{Vakkennis}

$1 \square$ Kennis van geneesmiddelen/zelfzorgartikelen

$1 \square$ Kennis van ziektebeelden

$1 \square$ Kennis van wet-en regelgeving

Vakvaardigheden 
$1 \square \quad$ Bereiden van geneesmiddelen

$1 \square$ Recepteren van geneesmiddelen

$1 \square$ Dispenseren (afleveren) van geneesmiddelen

$1 \square$ Computervaardigheden (ICT)

Andere specifieke vaardigheden

$1 \square$ Voorraad- en magazijnbeheer

$1 \square$ Secretariële werkzaamheden

$1 \square$ Realiseren, bewaken en bevorderen van kwaliteitsbeleid

$1 \square$ Anders, namelijk:

25. In welke vorm werd deze cursus aangeboden? (Meerdere antwoorden mogelijk)

$1 \square$ Cursus op locatie (buiten de werkplek)

$\square \quad$ Cursus op de werkplek

$1 \square \quad$ E-learning (cursus via computer/Internet)

$1 \square$ Zelfstudie via schriftelijk materiaal (boeken)

$1 \quad \square \quad$ Anders, namelijk:

26. Door wie is deze cursus betaald?

$1 \square$ Door mijzelf $\quad$ 200L1

$2 \square$ Door de werkgever $\quad$ 201L2

$3 \square$ Deels door mijzelf en deels door de werkgever

$4 \quad \square \quad$ Anders, namelijk:

27. Wie nam het initiatief voor deze cursus?

$\begin{array}{lll}1 & \square & \text { Ikzelf } \\ 2 & \square & \text { De werkgever }\end{array}$

$3 \square$ Beiden 
28. In wiens tijd werd deze cursus gevolgd?

$1 \quad \square \quad$ In werktijd / betaalde studietijd

$2 \quad \square \quad$ In mijn eigen tijd / vrije tijd

$3 \square$ Deels in werktijd en deels in eigen tijd

29. Wat is de belangrijkste reden waarom u deze cursus volgde?

(Slechts één antwoord mogelijk)

$01 \square \quad$ Om een tekort aan kennis en vaardigheden weg te werken 205L2

$02 \square$ Om bij te blijven

$03 \square$ Om mij verder te specialiseren

$04 \square$ Om promotie te kunnen maken / door te groeien

$05 \square$ De cursus was verplicht

$06 \square$ Om de aan de cursus gekoppelde salarisverhoging

$07 \square$ Persoonlijke interesse

Anders, namelijk:

30. Komen de in deze cursus opgedane kennis en vaardigheden van pas in uw werk in de openbare apotheek?

$1 \quad \square \quad \mathrm{Ja}$, ik gebruik de opgedane kennis en vaardigheden bij mijn werkzaamheden 209L1

$2 \square$ Ja, collega's maken gebruik van de kennis en vaardigheden die ik opdeed

$3 \square$ Ja, zowel ikzelf als mijn collega's gebruiken de opgedane kennis en vaardigheden in ons werk

$4 \quad \square \quad$ Nee, de opgedane kennis en vaardigheden komen niet van pas

31. Kunt u met een rapportcijfer tussen de 1 en 10 aangeven in hoeverre $u$ de volgende kennis en vaardigheden bezit?

\section{Algemene vaardigheden}

Cijfer

Mondelinge en schriftelijke communicatie

Omgaan met verantwoordelijkheden

Deskundigheid/ professionaliteit

Zelfstandigheid

Nauwkeurigheid/ zorgvuldigheid

Stressbestendigheid

Leidinggeven

Omgang/samenwerking met collega's

\section{Vakkennis}

Kennis van geneesmiddelen/zelfzorgartikelen 
Kennis van ziektebeelden

Kennis van wet- en regelgeving

\section{Vakvaardigheden}

Bereiden van geneesmiddelen

Recepteren van geneesmiddelen

Dispenseren (afleveren) van geneesmiddelen

Computervaardigheden (ICT)

\section{Andere specifieke vaardigheden}

Voorraad- en magazijnbeheer

Secretariële werkzaamheden

Realiseren, bewaken en bevorderen van kwaliteitsbeleid

32. Op welke manier denkt $u$ onderstaande kennis en vaardigheden het beste

op

\section{peil te houden?}

(Slechts één antwoord per kennis of vaardigheid mogelijk)

\begin{tabular}{|c|c|c|c|c|c|c|}
\hline & Het & este op & houden doo & & & \\
\hline Kennis en vaardigheden & $\begin{array}{l}\text { Cursus- } \\
\text { sen } \\
\text { volgen }\end{array}$ & $\begin{array}{l}\text { Team- } \\
\text { Trai- } \\
\text { ningen } \\
\text { volgen }\end{array}$ & $\begin{array}{l}\text { E-learning } \\
\text { (cursus via } \\
\text { computer/ } \\
\text { Internet) }\end{array}$ & $\begin{array}{l}\text { Zelfstu- } \\
\text { die via } \\
\text { schrifte- } \\
\text { lijk mate- } \\
\text { riaal } \\
\text { (boeken) }\end{array}$ & $\begin{array}{l}\text { Leren } \\
\text { op de } \\
\text { werkplek }\end{array}$ & $\begin{array}{l}\text { Leren } \\
\text { van } \\
\text { collega's }\end{array}$ \\
\hline $\begin{array}{l}\text { 1. Mondelinge en } \\
\text { schriftelijke communicatie }\end{array}$ & $1 \square$ & $1 \square$ & $1 \square$ & $1 \square$ & $1 \square$ & $1 \square 246$ L6+1 \\
\hline $\begin{array}{l}\text { 2. Kennis van } \\
\text { geneesmiddelen/ } \\
\text { zelfzorgartikelen }\end{array}$ & $1 \square$ & $1 \square$ & $1 \square$ & $1 \square$ & $1 \square$ & $1 \square 253 L 6+1$ \\
\hline $\begin{array}{l}\text { 3. Bereiden van } \\
\text { geneesmiddelen }\end{array}$ & $1 \square$ & $1 \square$ & $1 \square$ & $1 \square$ & $1 \square$ & $1 \square 260 \mathrm{~L} 6+1$ \\
\hline $\begin{array}{l}\text { 4.Computervaardigheden } \\
\text { (ICT) }\end{array}$ & 1 말 & $1 \square$ & $1 \square$ & $1 \square$ & $1 \square$ & $1 \square 267 \mathrm{~L} 6+1$ \\
\hline
\end{tabular}

33. Kunt u aangeven voor welke onderwerpen u behoefte heeft aan verdere bijof nascholing?

(Meerdere antwoorden mogelijk)

\section{Algemene vaardigheden}

$1 \square$ Mondelinge en schriftelijke communicatie

$1 \square$ Omgaan met verantwoordelijkheden

$\square$ Deskundigheid/professionaliteit

7-12-2004/11317/Nr.lijst Apothekersassistenten 10 
$1 \square$ Zelfstandigheid

$1 \square \quad$ Nauwkeurigheid/ zorgvuldigheid

$1 \square$ Stressbestendigheid

$1 \square$ Leidinggeven

$1 \square$ Omgang/samenwerking met collega's

\section{Vakkennis}

$1 \square$ Kennis van geneesmiddelen/zelfzorgartikelen

$1 \square$ Kennis van ziektebeelden

$1 \square$ Kennis van wet- en regelgeving

\section{Vakvaardigheden}

$1 \square$ Bereiden van geneesmiddelen

$1 \square$ Recepteren van geneesmiddelen

$1 \square$ Dispenseren (afleveren) van geneesmiddelen

$1 \square$ Computervaardigheden (ICT)

\section{Andere specifieke vaardigheden}

$1 \square$ Voorraact en magazijnbeheer

$1 \square$ Secretariële werkzaamheden

$1 \square$ Realiseren, bewaken en bevorderen van kwaliteitsbeleid

$1 \square$ Anders, namelijk:

34a. Worden er periodiek afspraken gemaakt over uw persoonlijke ontwikkeling of het volgen vancursussen?

En heeft u een persoonlijk ontwikkelingsplan (POP)?

$1 \quad \square$ Ja, er zijn afspraken gemaakt

296L1

$2 \square \mathrm{Ja}$, ik heb een persoonlijk ontwikkelingsplan (POP)

$3 \square$ Nee, maar ik wil wel graag zulke afspraken of een plan maken -> ga verder met vraag 35

$4 \quad \square$ Nee, maar ik heb ook geen behoefte aan zulke afspraken of een plan

$>$ ga verder met vraag 35 
34b. Bent u tevreden over de gemaakte afspraken of uw persoonlijk ontwikkelingsplan?

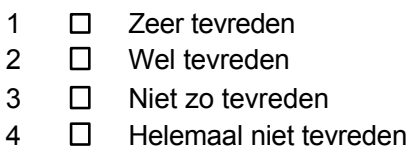

\section{Blok 6 Uw mening over de werksituatie}

35. In hoeverre hebben zich de afgelopen twee jaar veranderingen voorgedaan in uw werk als apothekersassistent? (Geef bij iedere verandering aan of er sprake is van een toename, afname of geen verandering)

Intensiteit patiëntenvoorlichting

Klantgerichtheid

Mondigheid van cliënten

Zelfstandig werken

Samenwerking in team

Gebruik van ICT

Koppeling met artsensysteem

Nieuw productaanbod

Verplaatsen farmaceutische zorg naar thuissituatie

Handverkoop

Zelf bereiden

Verzorgen van spreekuren

Begeleiden van assistenten in opleiding

Werkdruk

Vereiste geneesmiddelenkennis

Assistenten nemen taken over van apotheker

Apotheker neemt taken over van assistenten

Werknemers nemen taken van elkaar over

Andere verandering, namelijk:

$\begin{array}{ccc}\text { Toename } & \text { Afname } & \begin{array}{l}\text { Geen } \\ \text { verandering }\end{array} \\ 1 \square & 2 \square & 3 \square \quad 298 \text { L19 } \\ 1 \square & 2 \square & 3 \square \quad 317 \mathrm{~L} 2 \\ 1 \square & 2 \square & 3 \square \\ 1 \square & 2 \square & 3 \square \\ 1 \square & 2 \square & 3 \square \\ 1 \square & 2 \square & 3 \square \\ 1 \square & 2 \square & 3 \square \\ 1 \square & 2 \square & 3 \square \\ 1 \square & 2 \square & 3 \square \\ 1 \square & 2 \square & 3 \square \\ 1 \square & 2 \square & 3 \square \\ 1 \square & 2 \square & 3 \square \\ 1 \square & 2 \square & 3 \square \\ 1 \square & 2 \square & 3 \square \\ 1 \square & 2 \square & 3 \square \\ 1 \square & 2 \square & 3 \square \\ 1 \square & 2 \square & 3 \square \\ 1 \square & 2 \square & 3 \square \\ 1 \square & 2 \square & \end{array}$




\section{INTOMART GFK}

36. Bent $u$, alles bijeengenomen, tevreden met uw huidige baan?

$1 \quad \square \quad$ Zeer tevreden

319L1

$2 \square$ Wel tevreden

$3 \square \quad$ Niet zo tevreden

$4 \square$ Helemaal niet tevreden

37. Hoe tevreden bent u over de volgende aspecten van uw werk?

$\begin{array}{lcccc} & \begin{array}{l}\text { Zeer } \\ \text { tevreden }\end{array} & \begin{array}{l}\text { Wel } \\ \text { tevreden }\end{array} & \begin{array}{l}\text { Niet zo } \\ \text { tevreden }\end{array} & \begin{array}{l}\text { Helemaal } \\ \text { niet } \\ \text { tevreden }\end{array} \\ \text { Salaris } & 1 \square & 2 \square & 3 \square & 4 \square \\ \text { Werktijden } & 1 \square & 2 \square & 3 \square & 4 \square \\ \text { Zelfstandigheid } & 1 \square & 2 \square & 3 \square & 4 \square \\ \text { Werksfeer } & 1 \square & 2 \square & 3 \square & 4 \square \\ \text { Werkdruk } & 1 \square & 2 \square & 3 \square & 4 \square \\ \text { Inhoud van het werk } & 1 \square & 2 \square & 3 \square & 4 \square \\ \text { Loopbaanperspectieven } & 1 \square & 2 \square & 3 \square & 4 \square \\ \text { Scholingsfaciliteiten } & 1 \square & 2 \square & 3 \square & 4 \square \\ \text { Veiligheid op werkplek } & 1 \square & 2 \square & 3 \square & 4 \square \\ \text { Leidinggeven door apotheker } & 1 \square & 2 \square & 3 \square & 4 \square \\ \text { Aanwezigheid van apotheker } & 1 \square & 2 \square & 3 \square & 4 \square\end{array}$

38. Kunt $u$ aangeven met hoeveel plezier $u$ onderstaande werkzaamheden uitvoert?

(Indien u bepaalde werkzaamheden niet verricht, vult u dan 'niet van toepassing' in)

$\begin{array}{lccc}\begin{array}{l}\text { Met } \\ \text { plezier }\end{array} & \text { Neutraal } & \begin{array}{l}\text { Met } \\ \text { weinig } \\ \text { plezier }\end{array} & \text { N.v.t. } \\ 1 \square & 2 \square & 3 \square & 9 \square \\ 1 \square & 2 \square & 3 \square & 9 \square \\ 1 \square & 2 \square & 3 \square & 9 \square \\ 1 \square & 2 \square & 3 \square & 9 \square \\ 1 \square & 2 \square & 3 \square & 9 \square \\ 1 \square & 2 \square & 3 \square & 9 \square \\ 1 \square & 2 \square & 3 \square & 9 \square \\ 1 \square & 2 \square & 3 \square & 9 \square \\ 1 \square & 2 \square & 3 \square & 9 \square \\ 1 \square & 2 \square & 3 \square & 9 \square \\ 1 \square & 2 \square & 3 \square & 9 \square \\ 1 \square & 2 \square & 3 \square & 9 \square\end{array}$

Recepten aanschrijven (ontvangen en registreren)

Recepten uitvullen (pakken en stickers plakken)

Recepten afleveren (plus standaard voorlichting)

Bewaken van medicatie

Bereiden van geneesmiddelen

Bewaken van de voorraad

Farmaceutische patiëntenzorg

(speciale of bijzondere voorlichting)

Realiseren, bewaken en bevorderen van kwaliteitsbeleid

Leidinggeven

Begeleiden van assistenten in opleiding

Administratie

Financiën

7-12-2004/11317/Nr.lijst Apothekersassistenten 13 
(declaratieverkeer naar verzekeraars, loonadministratie etc.)

Bezorgen van geneesmiddelen

Schoonmaken en huishoudelijke taken

$1 \square \quad 2 \square \quad 3 \square \quad 9 \square$

Overige taken

39. Van welke onderstaande faciliteiten/regelingen maakt u gebruik? (Meerdere antwoorden mogelijk)

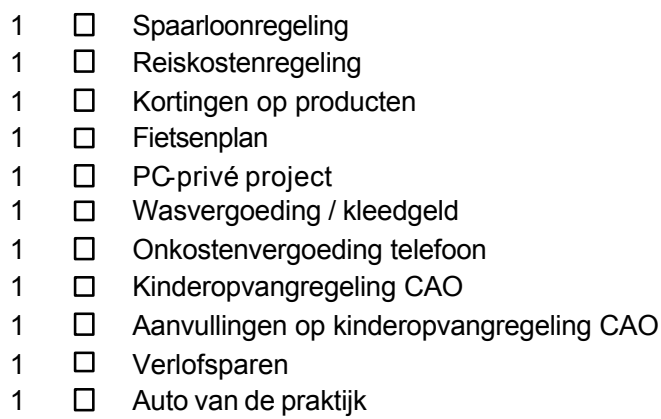

40. In hoeverre bent $u$ het eens met de volgende stellingen?

\begin{tabular}{|c|c|c|c|c|c|c|}
\hline & $\begin{array}{l}\text { Zeer } \\
\text { mee } \\
\text { eens }\end{array}$ & $\begin{array}{l}\text { Mee } \\
\text { eens }\end{array}$ & $\begin{array}{l}\text { Neut } \\
\text { traal }\end{array}$ & $\begin{array}{l}\text { Mee } \\
\text { oneens }\end{array}$ & $\begin{array}{l}\text { Zeer } \\
\text { mee } \\
\text { oneens }\end{array}$ & \\
\hline $\begin{array}{l}\text { Ik kan zelf beslissen in } \\
\text { welke volgorde ik mijn } \\
\text { werk verricht }\end{array}$ & $1 \square$ & $2 \square$ & $3 \square$ & $4 \square$ & $5 \square$ & 358L4 \\
\hline $\begin{array}{l}\text { Ik kan zelf mijn } \\
\text { werktempo bepalen }\end{array}$ & $1 \square$ & $2 \square$ & $3 \square$ & $4 \square$ & $5 \square$ & \\
\hline $\begin{array}{l}\text { lk kan zelf beslissen hoe } \\
\text { ik mijn werk doe }\end{array}$ & $1 \square$ & $2 \square$ & $3 \square$ & $4 \square$ & $5 \square$ & \\
\hline $\begin{array}{l}\text { Ik krijg voldoende } \\
\text { ondersteuning van mijn } \\
\text { leidinggevende }\end{array}$ & $1 \square$ & $2 \square$ & $3 \square$ & $4 \square$ & $5 \square$ & \\
\hline
\end{tabular}

41. Bent u momenteel (actief) op zoek naar een andere baan?

$1 \square$ Ja, ik zoek een baan als apothekersassistent in een andere openbare apotheek

362 L1

$2 \square$ Ja, ik zoek een baan als apothekersassistent buiten de openbare apotheek

$3 \square$ Ja, ik zoek een baan in een andere functie, maar wel binnen de sector

$4 \square$ Ja, ik zoek een baan in een andere functie, maar dan buiten de sector

$5 \square$ Nee, ik ben niet op zoek naar een andere baan 
42a. Denkt u over 5 jaar nog als apothekersassistent in de openbare apotheek

te

\section{werken?}

$1 \quad \square \quad \mathrm{Ja}$, in dezelfde openbare apotheek als waar ik nu werk $\rightarrow$ ga verder met vraag 43

$2 \square$ Ja, maar wel in een andere openbare apotheek

$3 \square \quad$ Nee, dan werk ik als apothekersassistent buiten de openbare apotheek

$4 \square$ Nee, dan werk ik niet meer als apothekersassistent

$5 \square$ Nee, dan ben ik gestopt met werken

42b. Waarom denkt u over 5 jaar niet meer in uw huidige apotheek te werken? (Meerdere antwoorden mogelijk)

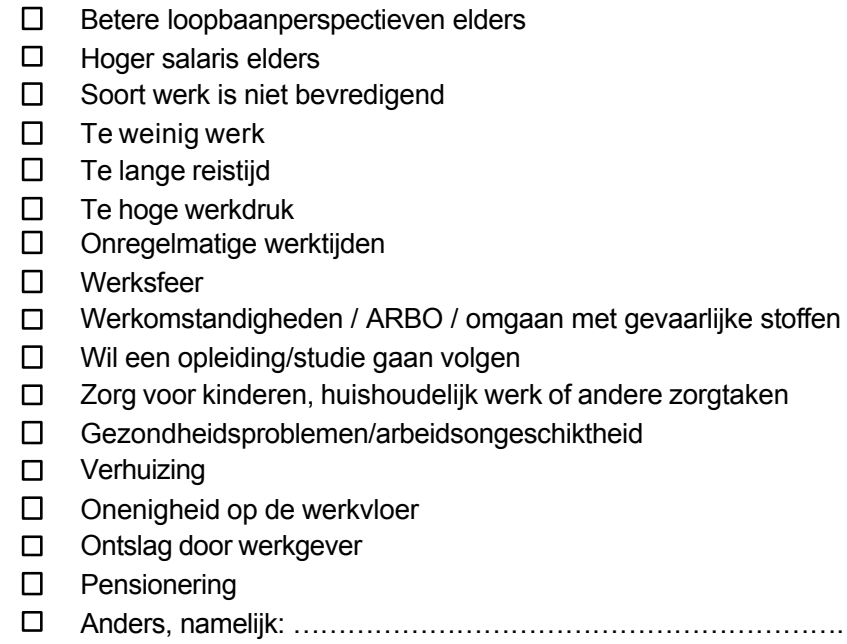

\section{Blok 7 Algemene informatie over uzelf}

Tenslotte volgen nog enkele algemene vragen over uzelf en uw gezinssituatie.

\section{Heeft u een partner waarmee u een gezamenlijke huishouding voert?}

\section{4a. Heeft u thuis wonende kinderen?}


44b. Hoe oud is uw jongste thuiswonende kind?

45. Tot welke bevolkingsgroep rekent u zichzelf?

$1 \quad \square \quad$ Nederlands

$3 \square$ Arubaans of Antilliaans

$4 \quad \square$ Turks

$5 \square$ Marokkaans

$6 \square$ Andere bevolkingsgroep, namelijk:

46. We houden u graag op de hoogte van de resultaten van dit onderzoek. Wilt $u$ een samenvatting van het eindrapport ontvangen?

47. Om de ontwikkelingen in de apotheekbranche op een kostenefficiënte manier te kunnen onderzoeken, wil de SBA in de toekomst een onderzoekspanel via Internet opzetten. Medewerkers in de openbare apotheek die aan dit panel deelnemen, worden een paar keer per jaar via e-mail benaderd om een korte vragenlijst over werken in de openbare apotheek in te vullen. Wij nodigen $u$ hierbij graag uit om aan dit onderzoek deel te nemen en uw mening te geven. Als u uw e-mail adres invult, nemen wij u op als deelnemer aan het volgende onderzoekspanel.

Mijn e-mail adres is: @.

Vanzelfsprekend worden ook deze antwoorden vertrouwelijk en anoniem behandeld.

\section{HARTELIJK DANK VOOR UW MEDEWERKING!}




\section{INTOMART GFK}

\section{Bijlage B Vragenlijst overige medewerkers}

<...NAW-gegevens incl. kikscode...>

Lotnummer $\quad<\ldots n-d n r \ldots>$

$<$ _..barcode t.b.v. postlkamer...>

\section{ARBEIDSMARKTMONITOR APOTHEKEN}

MEDEWERKERS 2004

\section{Internet?}

U kunt de vragenlijst ook via internet invullen!

Hoe gaat dat in zijn werk?

1. Bezoek: www.sbaweb.nl

2. klik op 'vragenlijst'. Dit is te vinden op de homepage onder de kop "NIEUW OP DE SITE".

3. Voer het volgende unieke wachtwoord in: < wachtwoord>

4. Als u via internet de vragenlijst invult, dan kunt $u$ deze vragenlijst weggooien. 


\section{INTOMART GFK}

\section{Blok 1 Opleiding en werkervaring}

In dit eerste vragenblok willen we u een aantal vragen stellen over de opleiding(en) die u gevolgd heeft en uw werkervaring.

1. Wat is de hoogste opleiding die u met een diploma hebt afgerond?

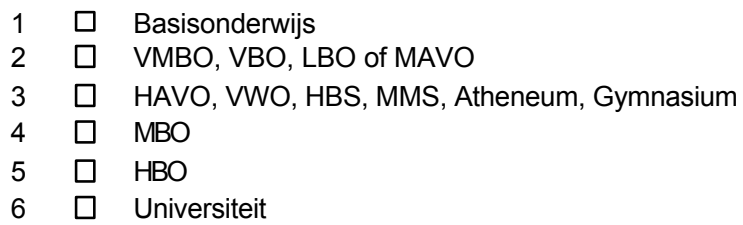

2. Wat was de richting van deze opleiding?

$1 \square$ Algemeen

$1 \square$ Farmaceutisch

Paramedisch

$1 \square$ Economie

$1 \square$ Sociaal-cultureel

$1 \square$ Techniek

$1 \square$ Onderwijs

$1 \square$ Anders, namelijk:

3. In welk jaar heeft $\mathrm{u}$ deze opleiding afgerond?

4. Hoe beoordeelt u de aansluiting tussen de door u gevolgde opleidingen en uw huidige werk in de openbare apotheek?

$\begin{array}{lll}1 & \square & \text { Uitstekend } \\ 2 & \square & \text { Goed } \\ 3 & \square & \text { Voldoende } \\ 4 & \square & \text { Matig } \\ 5 & \square & \text { Slecht }\end{array}$

5. Hoeveel jaar werkervaring heeft u?

(Tel alle jaren dat $u$ betaalde arbeid verrichtte, in welke functie dan ook, mee. Laat buiten beschouwing of $u$ al dan niet in deeltijd werkte.) 


\section{INTOMART GFK}

\section{Blok 2 Huidige werksituatie}

De volgende vragen gaan over uw huidige werksituatie.

Wanneer u in meerdere openbare apotheken werkt, ga dan uit van de werksituatie in de openbare apotheek waar u de meeste uren werkt.

6. Sinds wanneer werkt $u$ in deze apotheek?

(Vul het jaar van indiensttreding in)

7a. Bent $\mathrm{u}$ de afgelopen jaren heringetreden?

$1 \square \mathrm{Ja}$, in het jaar

7b. Hoeveel jaar heeft u uw loopbaan onderbroken? (hoeveel jaar bent u er in totaal 'tussenuit' geweest?) 040L2

jaar

8. Wat is uw functie volgens het nieuwe functiewaarderingssysteem?

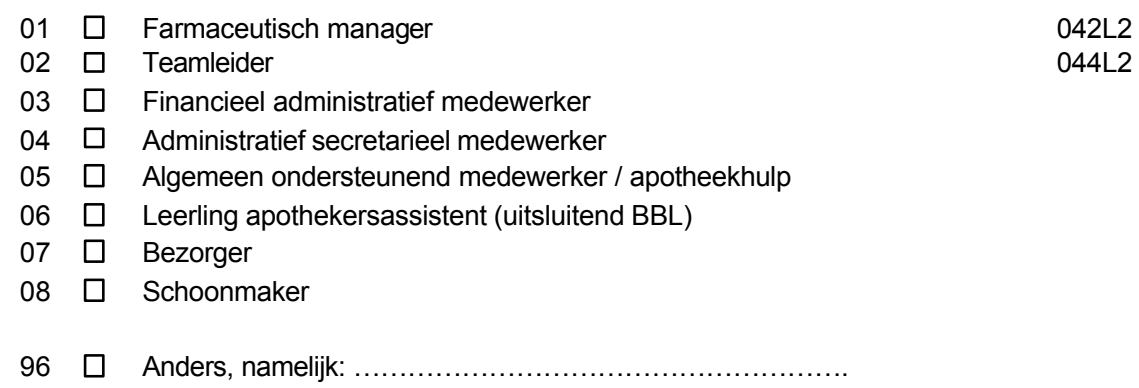

9. $\quad$ Bent $u$ tevreden met de indeling van uw functie in het nieuwe functiewaarderingssysteem?

\footnotetext{
$1 \square \quad$ Zeer tevreden

$2 \square$ Tevreden

$3 \square \quad$ Niet zo tevreden

$4 \quad \square$ Helemaal niet tevreden
} 


\section{INTOMART GFK}

10. Heeft u een vast of een tijdelijk contract, of werkt u via een uitzendbureau of op oproepbasis?

$1 \square$ Vast contract

$2 \square$ Tijdelijk contract met uitzicht op een vast contract

$3 \square$ Tijdelijk contract zonder uitzicht op een vast contract

$4 \quad \square \quad$ Uitzendcontract

$5 \quad \square \quad$ Contract op oproepbasis

11. Hoeveel uur werkt u feitelijk gemiddeld per week?

$$
\text { uur per week }
$$

12. En hoeveel uur zou u het liefst willen werken?

$$
\text { uur per week }
$$

13. Welke diensten draait $\mathbf{u}$ in de apotheek? (Meerdere antwoorden mogelijk)
$1 \quad \square \quad$ Dagdiensten
$1 \square$ Avonddiensten
$1 \square$ Nachtdiensten
$1 \square$ Zondagsdiensten
$1 \quad \square \quad$ Aanwezigheidsdiensten
$1 \square$ Bereikbaarheidsdiensten

054L6+1

14. Werkt u volgens een vast of wisselend rooster?

$1 \square$ Vast rooster

$2 \square$ Wisselend rooster

\section{Blok 3 Arbeidsomstandigheden}

15. Hoe ervaart u de werkdruk in uw werk?

(Geef uw mening aan door een kruisje te zetten)

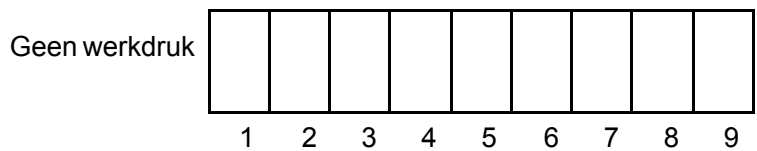

Extreem hoge 062L2 werkdruk 


\section{INTOMART GFK}

16. Kunt u voor uw werk aangegeven of u altijd, vaak, soms, of nooit te maken hebt met de volgende aspecten?

$\begin{array}{lllll} & \text { Altijd } & \text { Vaak } & \text { Soms } & \text { Nooit } \\ \text { Hoge tijdsdruk } & 1 \square & 2 \square & 3 \square & 4 \square \\ \text { Lichamelijk zwaar werk } & 1 \square & 2 \square & 3 \square & 4 \square \\ \text { Geestelijk zwaar werk } & 1 \square & 2 \square & 3 \square & 4 \square \\ \text { Fysieke omstandigheden als lawaai, } & 1 \square & 2 \square & 3 \square & 4 \square \\ \text { tocht, hoge of lage temperaturen, stof, } & & & & \\ \text { etc. } & 1 \square & 2 \square & 3 \square & 4 \square \\ \text { Contact met gevaarlijke stoffen } & 1 \square & 2 \square & 3 \square & 4 \square \\ \text { Eentonig werk } & 1 \square & 2 \square & 3 \square & 4 \square \\ \text { Agressie/geweld } & 1 \square & 2 \square & 3 \square & 4 \square \\ \text { Pestgedrag } & & & & \end{array}$

17a. Hoe vaak heeft u zich in de afgelopen 12 maanden ziek gemeld?

(Indien u zich 0 keer ziek heeft gemeld, ga dan verder met vraag 18)

17b. Hoeveel dagen heeft u de afgelopen 12 maanden van uw werk verzuimd wegens ziekte?

(Tel zwangerschapsverlof niet mee)

$$
\text { dagen }
$$

(Indien u 0 dagen hebt verzuimd, ga dan verder met vraag 18)

17c. Lag de oorzaak van het laatste of eventueel uw huidige ziekteverzuim bij het werk of de werksituatie?

(Meerdere antwoorden mogelijk)

$1 \square$ Nee, oorzaak had niet met het werk te maken

077L4+1

$1 \square$ Ja, oorzaak lag bij de hoge werkdruk

$1 \square$ Ja, oorzaak lag bij de zware lichamelijke belasting van het werk

$1 \square$ Ja, oorzaak lag bij een ander aspect van het werk 


\section{INTOMART GFK}

\section{Blok 4 Taken en werkzaamheden}

\section{Hoeveel procent van uw werktijd besteedt $u$ aan onderstaande werkzaamheden?}

(In totaal moeten uw antwoorden optellen tot 100\%)

Leidinggeven

Begeleiden van assistenten in opleiding

Realiseren, bewaken en bevorderen van kwaliteitsbeleid

Farmaceutische patiëntenzorg (speciale of bijzondere

voorlichting)

Recepten aanschrijven (ontvangen en registreren)

Recepten uitvullen (pakken en stickers plakken)

Recepten afleveren (plus standaard voorlichting)

Bewaken van medicatie

Bereiden van geneesmiddelen

Bewaken van de voorraad

Administratie

Financiën (loonadministratie, declaratieverkeer naar verzekeraars etc.)

Bezorgen van geneesmiddelen

Schoonmaken en huishoudelijke taken

Overige taken

\section{Totaal}

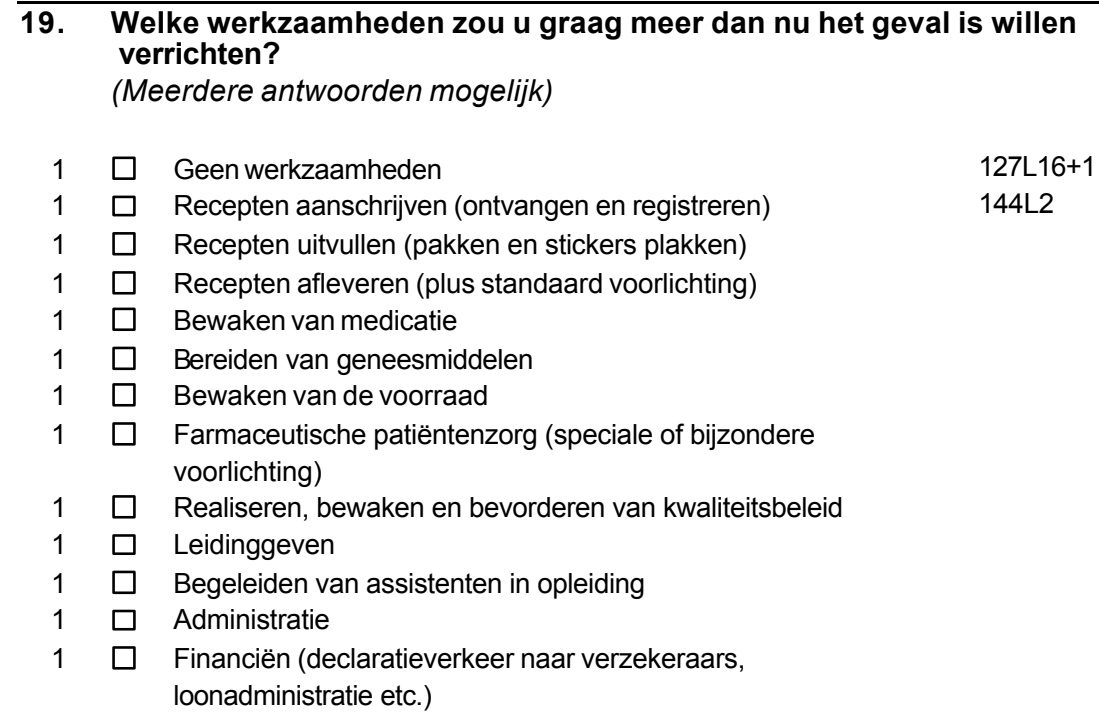




\section{INTOMART GFK}

$1 \square$ Bezorgen van geneesmiddelen

$1 \square$ Schoonmaken en huishoudelijke taken

$1 \square$ Overige taken, namelijk:

20. Verricht $\mathrm{u}$ in uw huidige baan weleens werkzaamheden die strikt genomen niet bij uw functie horen?

(Meerdere antwoorden mogelijk)

$1 \quad \square \quad \mathrm{Ja}$, taken uit hogere functies

$146 \mathrm{~L} 3+1$

$1 \quad \mathrm{Ja}$, taken uit lagere functies

$1 \square \mathrm{Nee}$

\section{Blok 5 Cursussen en vaardigheden}

21. Heeft $u$ de afgelopen 12 maanden één of meerdere aan uw werk gerelateerde cursussen gevolgd?

$1 \square \mathrm{Ja}$

$2 \square \mathrm{Nee}$

-> ga verder met vraag 30

22. Heeft u samen met (een groot deel van) uw team aan teamtrainingen deel genomen?

$1 \quad \square \quad \mathrm{Ja}$

151L1

$2 \square \mathrm{Nee}$

23. De volgende vragen gaan over de laatste cursus die u gevolgd heeft. Op welke terreinen lag deze cursus?

(Meerdere antwoorden mogelijk)

Algemene vaardigheden

152L $19+1$

$1 \square$ Mondelinge en schriftelijke communicatie

172L2

$1 \square$ Omgaan met verantwoordelijkheden

$1 \square$ Deskundigheid/professionaliteit

$1 \square$ Zelfstandigheid

$1 \square$ Nauwkeurigheid/ zorgvuldigheid

$1 \square$ Stressbestendigheid

$1 \square \quad$ Leidinggeven

$1 \square$ Omgang/samenwerking met collega's 
Vakkennis

$1 \square$ Kennis van geneesmiddelen/zelfzorgartikelen

$1 \square$ Kennis van ziektebeelden

$1 \square$ Kennis van wet- en regelgeving

Vakvaardigheden

$1 \square \quad$ Bereiden van geneesmiddelen

$1 \square$ Recepteren van geneesmiddelen

$1 \square$ Dispenseren (afleveren) van geneesmiddelen

$1 \square$ Computervaardigheden (ICT)

\section{Andere specifiek e vaardigheden}

$1 \square$ Voorraad- en magazijnbeheer

$1 \square$ Secretariële werkzaamheden

$1 \square$ Realiseren, bewaken en bevorderen van kwaliteitsbeleid

$1 \square$ Anders, namelijk:

24. In welke vorm werd deze cursus aangeboden? (Meerdere antwoorden mogelijk)

\footnotetext{
$1 \square \quad$ Cursus op locatie (buiten de werkplek)

$1 \quad \square \quad$ Cursus op de werkplek

$\square \quad$ E-learning (cursus via computer/Internet)

$1 \square$ Zelfstudie via schriftelijk materiaal (boeken)

$1 \square$ Anders, namelijk:
}

25. Door wie is deze cursus betaald?
$1 \square$ Door mijzelf
$2 \quad \square \quad$ Door de werkgever
$3 \square$ Deels door mijzelf en deels door de werkgever
$4 \quad \square \quad$ Anders, namelijk:

183L2 


\section{INTOMART GFK}

26. Wie nam het initiatief voor deze cursus?

$1 \square$ Ikzelf

185L1

$2 \square$ De werkgever

$3 \square$ Beiden

27. In wiens tijd werd deze cursus gevolgd?

$1 \quad \square \quad$ In werktijd / betaalde studietijd

$186 \mathrm{~L} 1$

$2 \square$ In mijn eigen tijd / vrije tijd

$3 \square$ Deels in werktijd en deels in eigen tijd

28. Wat is de belangrijkste reden waarom u deze cursus volgde?

(Slechts één antwoord mogelijk)

$01 \square$ Om een tekort aan kennis en vaardigheden weg te werken 187L2

$02 \square$ Om bij te blijven

$03 \square$ Om mij verder te specialiseren

$04 \square$ Om promotie te kunnen maken / door te groeien

$05 \square$ De cursus was verplicht

$06 \square$ Om de aan de cursus gekoppelde salarisverhoging

$07 \square$ Persoonlijke interesse

$\square \quad$ Anders, namelijk:

29. Komen de in deze cursus opgedane kennis en vaardigheden van pas in uw werk in de openbare apotheek?

$1 \square$ Ja, ik gebruik de opgedane kennis en vaardigheden bij mijn werkzaamheden 191L1

$2 \square$ Ja, collega's maken gebruik van de kennis en vaardigheden die ik opdeed

$3 \square$ Ja, zowel ikzelf als mijn collega's gebruiken de opgedane kennis en vaardigheden in ons werk

$4 \quad \square \quad$ Nee, de opgedane kennis en vaardigheden komen niet van pas 
30. Kunt u met een rapportcijfer tussen de 1 en 10 aangeven in hoeverre u de volgende kennis en vaardigheden bezit?

\section{Algemene vaardigheden}

Cijfer

Mondelinge en schriftelijke communicatie

Omgaan met verantwoordelijkheden

192L18x2

Deskundigheid/ professionaliteit

Zelfstandigheid

Nauwkeurigheid/ zorgvuldigheid

Stressbestendigheid

Leidinggeven

Omgang/samenwerking met collega's

\section{Vakkennis}

Kennis van geneesmiddelen/zelfzorgartikelen

Kennis van ziektebeelden

Kennis van wet- en regelgeving

\section{Vakvaardigheden}

Bereiden van geneesmiddelen

Recepteren van geneesmiddelen

Dispenseren (afleveren) van geneesmiddelen

Computervaardigheden (ICT)

\section{Andere specifieke vaardigheden}

Voorraad- en magazijnbeheer

Secretariële werkzaamheden

Realiseren, bewaken en bevorderen van kwaliteitsbeleid 
31. Kunt $u$ aangeven voor welke onderwerpen $u$ behoefte heeft aan verdere bij- of nascholing?

(Meerdere antwoorden mogelijk)

\section{Algemene vaardigheden}

$1 \square$ Mondelinge en schriftelijke communicatie 228L19+1

$1 \square$ Omgaan met verantwoordelijkheden

$1 \square$ Deskundigheid/professionaliteit

$1 \square$ Zelfstandigheid

$1 \square \quad$ Nauwkeurigheid/zorgvuldigheid

$1 \square$ Stressbestendigheid

$1 \square \quad$ Leidinggeven

$1 \square$ Omgang/samenwerking met collega's

\section{Vakkennis}

$1 \square$ Kennis van geneesmiddelen/zelfzorgartikelen

$1 \square$ Kennis van ziektebeelden

$1 \square$ Kennis van wet- en regelgeving

\section{Vakvaardigheden}

$1 \square$ Bereiden van geneesmiddelen

$1 \square$ Recepteren van geneesmiddelen

$1 \square$ Dispenseren (afleveren) van geneesmiddelen

$1 \square$ Computervaardigheden (ICT)

\section{Andere specifieke vaardigheden}

$1 \square$ Voorraact en magazijnbeheer

$1 \square$ Secretariële wөrzaamheden

$1 \square$ Realiseren, bewaken en bevorderen van kwaliteitsbeleid

$\square$ Anders, namelijk:

32a. Worden er periodiek afspraken gemaakt over uw persoonlijke ontwikkeling of het volgen van cursussen?

En heeft u een persoonlijk ontwikkelingsplan (POP)?

$1 \quad \square$ Ja, er zijn afspraken gemaakt

$2 \square \mathrm{Ja}$, ik heb een persoonlijk ontwikkelingsplan (POP)

$3 \square$ Nee, maar ik wil wel graag zulke afspraken of een plan maken $\rightarrow$ ga verder met vraag 33

$4 \square$ Nee, maar ik heb ook geen behoefte aan zulke afspraken of een plan -> ga verder met vraag 33 


\section{INTOMART GFK}

32b. Bent u tevreden over de gemaakte afspraken of uw persoonlijk ontwikkelingsplan?
$1 \quad \square \quad$ Zeer tevreden
$\square \quad$ Wel tevreden
$\square \quad$ Niet zo tevreden
$4 \quad \square$ Helemaal niet tevreden

251L1

\section{Blok 6 BBL - Opleiding}

33. Werkt $u$ op dit moment in de apotheek als onderdeel van uw BBL opleiding tot apothekersassistent (beroepspraktijkvormingsplek)?

$1 \quad \square \quad \mathrm{Ja}$

$2 \square \mathrm{Nee}$

-> ga verder met vraag 36

34. Hoe tevreden bent u over de volgende aspecten?

$\begin{array}{cccc}\text { Zeer } & \text { Wel } & \text { Niet } & \text { Helemaal } \\ \text { tevreden } & \text { tevreden } & \text { zo } & \text { niet } \\ \text { tevreden } & \text { tevreden }\end{array}$

$\begin{array}{lllll}\text { Begeleiding in de apotheek } & 1 \square & 2 \square & 3 \square & 4 \square \\ \text { Begeleiding vanuit het ROC } & 1 \square & 2 \square & 3 \square & 4 \square \\ \text { Aansluiting school - praktijk } & 1 \square & 2 \square & 3 \square & 4 \square\end{array}$

35. En hoe beoordeelt u de aansluiting tussen de BBL-opleiding en uw huidige werk in de openbare apotheek?
$\square \quad$ Uitstekend
$\square$ Goed
$\square \quad$ Voldoende
$\square \quad$ Matig
$\square \quad$ Slecht 


\section{INTOMART GFK}

\section{Blok 7 Uw mening over de werksituatie}

36. Bent $\mathrm{u}$, alles bijeengenomen, tevreden met uw huidige baan?

$1 \square \quad$ Zeer tevreden

$2 \square$ Wel tevreden

$3 \square \quad$ Niet zo tevreden

$4 \square$ Helemaal niet tevreden

37. Hoe tevreden bent u over de volgende aspecten van uw werk?

$\begin{array}{lcccc} & \begin{array}{c}\text { Zeer } \\ \text { tevreden }\end{array} & \begin{array}{c}\text { Wel } \\ \text { tevreden }\end{array} & \begin{array}{c}\text { Niet } \\ \text { zo } \\ \text { tevreden }\end{array} & \begin{array}{c}\text { Helemaal } \\ \text { niet } \\ \text { tevreden }\end{array} \\ \text { Salaris } & 1 \square & 2 \square & 3 \square & 4 \square \\ \text { Werktijden } & 1 \square & 2 \square & 3 \square & 4 \square \\ \text { Zelfstandigheid } & 1 \square & 2 \square & 3 \square & 4 \square \\ \text { Werksfeer } & 1 \square & 2 \square & 3 \square & 4 \square \\ \text { Werkdruk } & 1 \square & 2 \square & 3 \square & 4 \square \\ \text { Inhoud van het werk } & 1 \square & 2 \square & 3 \square & 4 \square \\ \text { Loopbaanperspectieven } & 1 \square & 2 \square & 3 \square & 4 \square \\ \text { Scholingsfaciliteiten } & 1 \square & 2 \square & 3 \square & 4 \square \\ \text { Veiligheid op werkplek } & 1 \square & 2 \square & 3 \square & 4 \square \\ \text { Leidinggeven door apotheker } & 1 \square & 2 \square & 3 \square & 4 \square \\ \text { Aanwezigheid van apotheker } & 1 \square & 2 \square & 3 \square & 4 \square\end{array}$




\section{INTOMART GFK}

38. Kunt $u$ aangeven met hoeveel plezier $u$ onderstaande werkzaamheden uitvoert?

(Indien u bepaalde werkzaamheden niet verricht, vult u dan 'niet van toepassing' in)

38. Kunt $\mathrm{u}$ aangeven met hoeveel plezier $\mathrm{u}$ onderstaande werkzaamheden uitvoert?

(Indien u bepaalde werkzaamheden niet verricht, vult u dan 'niet van toepassing' in)

\section{Leidinggeven}

Begeleiden van assistenten in opleiding

Realiseren, bewaken en bevorderen van kwaliteitsbeleid

Farmaceutische patiëntenzorg

Recepten aanschrijven (ontvangen en
registreren)

Recepten uitvullen (pakken en stickers plakken)

Recepten afleveren (plus standaard voorlichting)

Bewaken van medicatie

Bereiden van genees middelen

Bewaken van de voorraad

Administratie

Financiën

(declaratieverkeer naar verzekeraars,

loonadministratie etc.)

Bezorgen van geneesmiddelen

Schoonmaken en huishoudelijke taken

Overige taken (speciale of bijzondere voorlichting)

$\begin{array}{ccc}\begin{array}{c}\text { Met } \\ \text { plezier }\end{array} & \begin{array}{c}\text { Netraal } \\ \text { weinig } \\ \text { plezier }\end{array} & \begin{array}{c}\text { Niet van } \\ \text { toepas - } \\ \text { sing }\end{array}\end{array}$

\begin{tabular}{|c|c|c|}
\hline $1 \square$ & $2 \square$ & $3 \square$ \\
\hline $1 \square$ & $2 \square$ & $3 \square$ \\
\hline $1 \square$ & $2 \square$ & $3 \square$ \\
\hline $1 \square$ & $2 \square$ & $3 \square$ \\
\hline $1 \square$ & $2 \square$ & $3 \square$ \\
\hline $1 \square$ & $2 \square$ & $3 \square$ \\
\hline $1 \square$ & $2 \square$ & $3 \square$ \\
\hline $1 \square$ & $2 \square$ & $3 \square$ \\
\hline $1 \square$ & $2 \square$ & $3 \square$ \\
\hline $1 \square$ & $2 \square$ & $3 \square$ \\
\hline $1 \square$ & $2 \square$ & $3 \square$ \\
\hline $1 \square$ & $2 \square$ & $3 \square$ \\
\hline $1 \square$ & $2 \square$ & $3 \square$ \\
\hline $1 \square$ & $2 \square$ & $3 \square$ \\
\hline $1 \square$ & $2 \square$ & $3 \square$ \\
\hline
\end{tabular}

269L15

39. Van welke onderstaande faciliteiten/regelingen maakt u gebruik? (Meerdere antwoorden mogelijk)
$1 \quad$ Spaarloonregeling
$1 \square$ Reiskostenregeling
$1 \quad$ Kortingen op producten
$1 \square$ Fietsenplan
$1 \square$ PG-privé project
$1 \square$ Wasvergoeding / kleedgeld
$1 \square$ Onkostenvergoeding telefoon
$1 \square$ Kinderopvangregeling $\mathrm{CAO}$ 


\section{INTOMART GFK}
$1 \quad \square \quad$ Aanvullingen op kinderopvangregeling CAO
$1 \square$ Verlofsparen
$1 \square$ Auto van de praktijk

40. In hoeverre bent $u$ het eens met de volgende stellingen?

\begin{tabular}{|c|c|c|c|}
\hline $\begin{array}{c}\text { Zeer } \\
\text { mee eens }\end{array}$ & $\begin{array}{l}\text { Mee } \\
\text { eens }\end{array}$ & Neutraal & $\begin{array}{c}\text { Mee } \\
\text { oneens }\end{array}$ \\
\hline
\end{tabular}

Ik kan zelf beslissen in welke

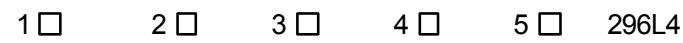
volgorde ik mijn werk verricht Ik kan zelf mijn werktempo bepalen

Ik kan zelf beslissen hoe ik mijn werk doe

Ik krijg voldoende ondersteuning van mijn leidinggevende

$1 \square \quad 2 \square \quad 3 \square \quad 4 \square \quad 5 \square$

$1 \square \quad 2 \square \quad 3 \square \quad 4 \square \quad 5 \square$

$1 \square \quad 2 \square \quad 3 \square \quad 4 \square \quad 5 \square$

\section{Blok 7 Algemene informatie over uzelf}

Tenslotte volgen nog enkele algemene vragen over uzelf en uw gezinssituatie.

41. Heeft u een partner waarmee u een gezamenlijke huishouding voert?

$1 \square \mathrm{Ja}$

$1 \square \quad \mathrm{Nee}$

42a. Heeft u thuiswonende kinderen?

$1 \square \mathrm{Ja}$, ik heb ......... kinderen thuiswonen

42b. Hoe oud is uw jongste thuiswonende kind?

43. Tot welke bevolkingsgroep rekent u zichzelf?

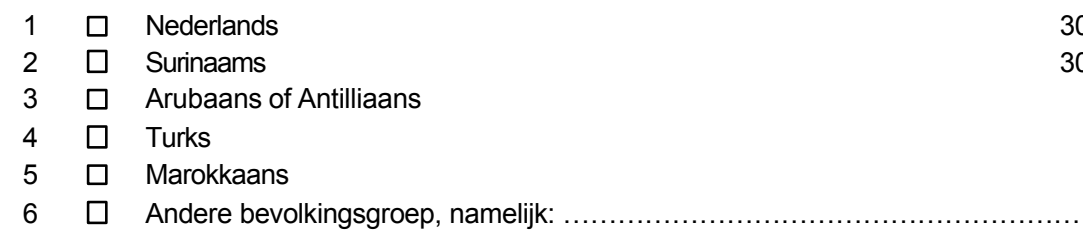


44. We houden u graag op de hoogte van de resultaten van dit onderzoek. Wilt u een samenvatting van het eindrapport ontvangen?

$1 \quad \square \mathrm{Ja}$

$2 \square \mathrm{Nee}$

45. Om de ontwikkelingen in de apotheekbranche op een kostenefficiënte manier te kunnen onderzoeken, wil de SBA in de toekomst een onderzoekspanel via Internet opzetten. Medewerkers in de openbare apotheek die aan dit panel deelnemen, worden een paar keer per jaar via e-mail benaderd om een korte vragenlijst over werken in de openbare apotheek in te vullen. Wij nodigen u hierbij graag uit om aan dit onderzoek deel te nemen en uw mening te geven. Als u uw e-mail adres invult, nemen wij u op als deelnemer aan het volgende onderzoekspanel.

Mijn e-mail adres is:

@

$309 L 60$

Vanzelfsprekend worden ook deze antwoorden vertrouwelijk en anoniem behandeld.

\section{HARTELIJK DANK VOOR UW MEDEWERKING!}

